Portland State University

PDXScholar

$1-1-2011$

Potential for Speciation in Mammals Following Vast, Late Miocene Volcanic Interruptions in the Pacific Northwest

Ryan Thomas McKenna

Portland State University

Follow this and additional works at: https://pdxscholar.library.pdx.edu/open_access_etds

Part of the Geology Commons

Let us know how access to this document benefits you.

Recommended Citation

McKenna, Ryan Thomas, "Potential for Speciation in Mammals Following Vast, Late Miocene Volcanic Interruptions in the Pacific Northwest" (2011). Dissertations and Theses. Paper 726.

https://doi.org/10.15760/etd.726

This Thesis is brought to you for free and open access. It has been accepted for inclusion in Dissertations and Theses by an authorized administrator of PDXScholar. Please contact us if we can make this document more accessible: pdxscholar@pdx.edu. 
Potential for Speciation in Mammals Following Vast, Late Miocene Volcanic Interruptions in the Pacific Northwest

by

Ryan Thomas Paul McKenna
A thesis submitted in partial fulfillment of the requirements for the degree of
Master of Science
in
Geology

Thesis Committee:

Michael L. Cummings, Chair

Christina L. Hulbe

Jeffrey A. Fletcher

Portland State University

(C)2011 
Abstract

The impact of large-scale volcanic eruptions on landscapes can affect many processes ranging from interrupting or redirecting regional soil forming processes and hydrological systems to generating temporary changes in global climate. Though more studies exist every year, less is known of the direct impact of large-scale volcanic eruptions on ecosystems and extinction, while even less is known of their impact on speciation. In deposits throughout the Pacific Northwest a special combination and association of volcanic magnitude with palaeoecological yield frequently presents unique prospects for inquiry. In this study, particular attention is given to large, late Miocene ash-flow tuffs of central and eastern Oregon, the Rattlesnake Tuff among them. Additionally, a scenario is tested whereby populations become isolated from one another across the expanse of ash-flow tuff and enclosed by nearby physical barriers. Exploration into this scenario and the effects of ecological recovery on speciation in mammals are made through a cellular automaton created here and speciation modeling by H.A. Orr. The cellular automaton is validated by a small data set from New Zealand with results of all models compared to studies in ecology, the fossil record, genetics, and island evolution. Results suggest ecosystem recovery is much faster than mammalian species origination rates. Though evolution in mammals is known to occur over relatively short intervals of time $\left(10^{1}-10^{3} \mathrm{yrs}\right)$, based on model comparisons, primary productivity generally returns to its carrying capacity two orders of magnitude $\left(10^{2}-10^{3}\right.$ vs. $\left.\geq 10^{4} \mathrm{yrs}\right)$ faster than mammalian speciation. 


\section{For Rebecca,}

there's no place else like us. 


\section{Acknowledgements}

I first considered the effects of large ash-flows on ecological recovery and mammalian diversity during a paleontology internship at John Day Fossil Beds NM in the summer of 2005. In the beginning it seemed ash-flows were common to every time period represented by the outcrops we prospected. Later on, working out the stratigraphy with the help of then staff paleontologists Ted Fremd, Scott Foss, Regan Dunn, and Matt Smith, I realized I was observing a few, very extensive ash-flows. I specifically recall being tested by Scott Foss as he pointed to the Rattlesnake Tuff, which at the time seemed like a random tuff in the hills overlooking his house in Dayville, Oregon. That same tuff was literally_nearly at eye level—eroding into Regan Dunn's backyard further east in Mt. Vernon. To later find out the Rattlesnake Tuff is also in outcrops more than $150 \mathrm{~km}$ south was nothing less than mind blowing. This undetermined relationship between extensive ash-flows and ecological and evolutionary responses was branded into my thoughts when I internshiped again at the Monument in 2007 following the completion of my Bachelor's degree in Geology at PSU. Without these people and my experiences working at the Monument this study likely never happens.

Nearing the end of my second internship at the Monument, I was approached by Mike Cummings, advisor to my Honor's thesis and undergraduate degree, to see if I would like to continue my education and assist in teaching in the University Studies and Geology Departments at Portland State University. When I pitched my research idea to Mike I had little notion as to what numerical or field methodologies I would, should, or could use to conduct or focus the research. Mike never batted an eye. He is an advisor 
whose guidance has always served me well. In my experience, Mike, as an advisor, is an inquirer, not a supervisor. In my opinion, this characteristic engenders genuine discussion and necessary intellectual growth. Since, at times, the process of conducting research can have precarious effects on human emotions; this approach has served to bring balance to these moments of uncertainty. Mike has always made me feel we are on equal ground. I cannot say enough how this has helped me. Thanks fall short.

Others who directly helped me with this thesis also served as counselers in building it a more solid foundation. The other members of my committee (Christina hulbe and Jeff Fletcher) stand out the most. Christina gave many weeks to the thesis overall, but she most especially helped me with taking thoughts and concepts of the ecological problem into the model I built. Like Christina, Jeff helped me with the modeling, but he also asked questions I would never have thought of that no one else did either. Additionally, I thank Martin Streck for data he provided, general discussions on largescale ash-flow tuffs, and his honesty and support.

This thesis fulfills the requirements for my second degree from PSU's Geology Department. Much talk is made in the student lounge speculating on the best way to continue one's education; to stay or move on. As I have gradually met different people with different backgrounds from different departments in different schools I conclude the world is what you make of it. I believe this thesis honors this sentiment and the hours, weeks, months, and years I, and all those involved in the Geology Department, have devoted to an undeniably greater end.

With that, I thank the Geology Department for the education and empowerment it has provided me. I now have access to internal resources that allow me to pursue my own 
ideas to completion. This is highly gratifying. I also thank my graduate and undergraduate comrades for their patience, companionship, many conversations, and undeserved help and beer over the years we have shared common spaces and goals. I would also like to thank Barb Shaw and Tom Lindsey. Barb, Tom and I for quite a while were likely the only three people on campus with a pure, unadulterated interest in paleontology. For all the wonders of hydrogeology, landslides, or just plain basalt that are present in the department, it's been nice to know I'm not alone. There is a knowing familiarity I feel we have that we share with no one else. Perhaps Cameron Tompkins can take my place if he hasn't already.

Beyond the department and campus, I would like to acknowledge the patience and love of all my friends. Many of my friends in Portland have never known me to not be in school. I am also forever severely indebted to the love, patience, and support of my family. We are apart for such long periods I feel like Rip Van Winkle when I see them. Lastly, my wife Rebecca is responsible for giving me the confidence to go to school in the first place, so I blame her the most. Thus, after nearly four years of operating in good faith with as much due diligence while mustering up the courage of my convictions, my chance to shine has been in rolling with the punches and going with the flow...

Parkview

Portland, Oregon $\quad$ R.T.P. McK

April 15, 2010 


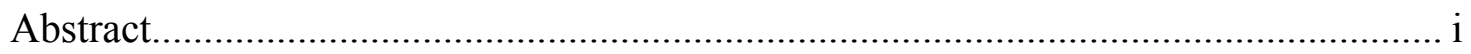

Acknowledgements..................................................................................... iii

List of tables..................................................................................................... viii

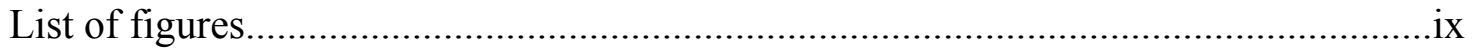

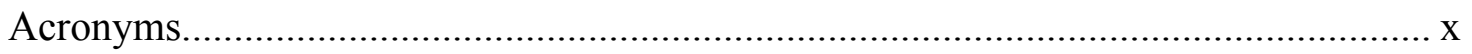

Chapter 1

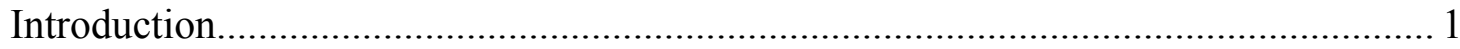

1.1 Specification of methodologies....................................................................... 2

Chapter 2

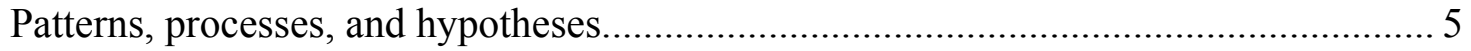

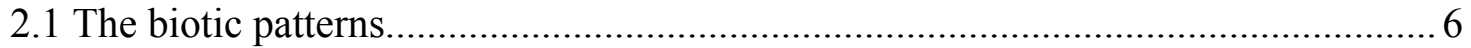

2.1.1 Abundant, widespread, and long-lived species...................................9

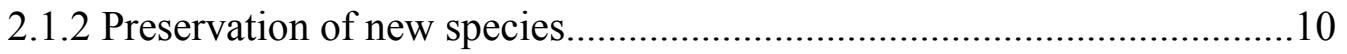

2.1.3 Modality in eutherian body mass distributions....................................10

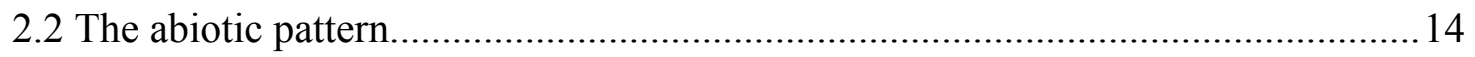

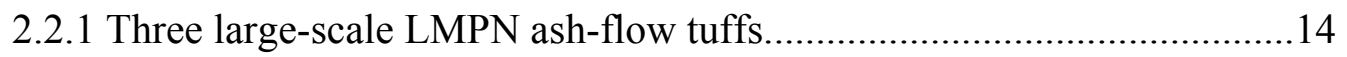

2.2.2 Terrain and relief in the LMPN.......................................................15

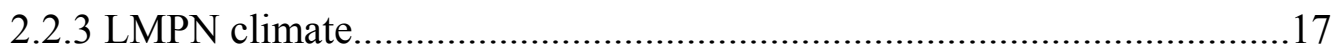

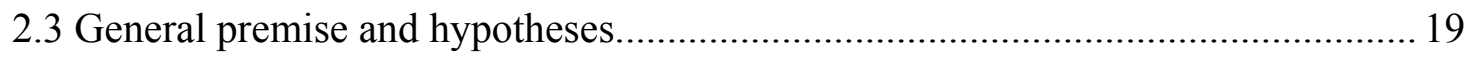

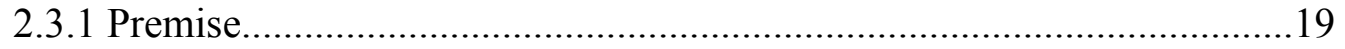

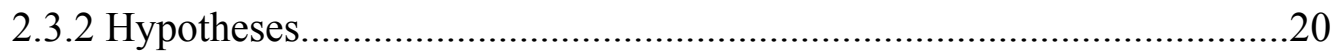

2.3.3 Isolation of populations and communities........................................22

Chapter 3

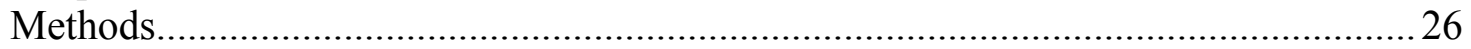

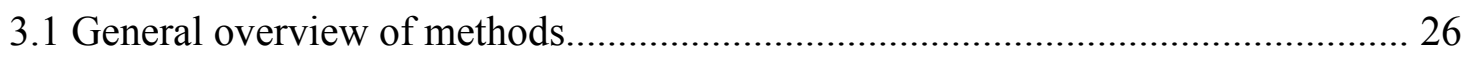

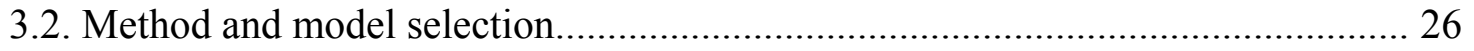

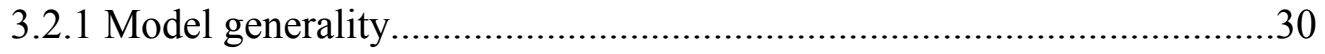

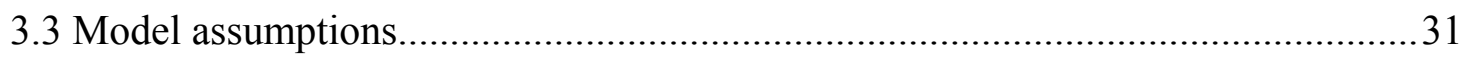




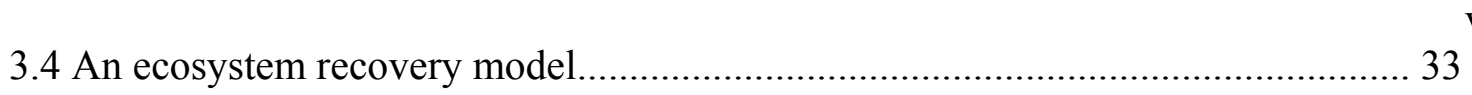

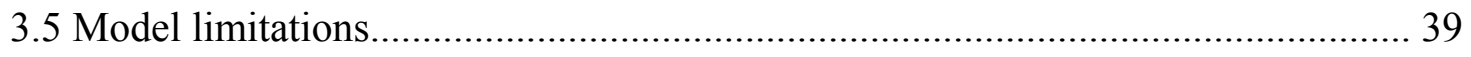

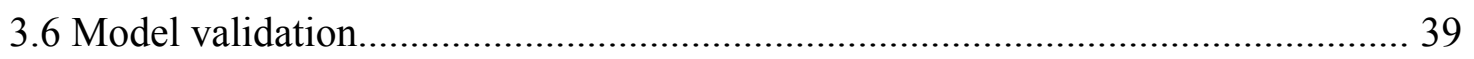

3.7 Cumulative probability and waiting time models for allopatric speciation........... 41

Chapter 4

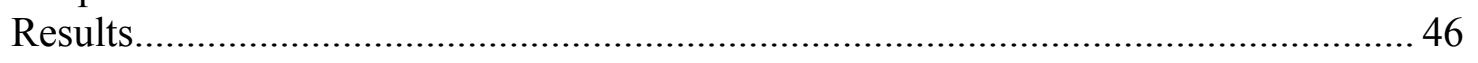

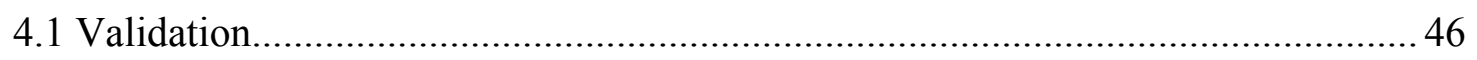

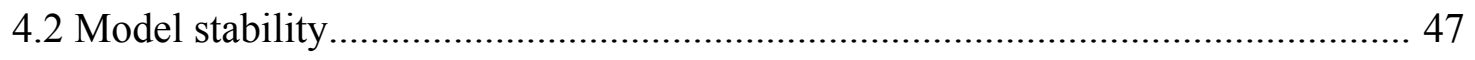

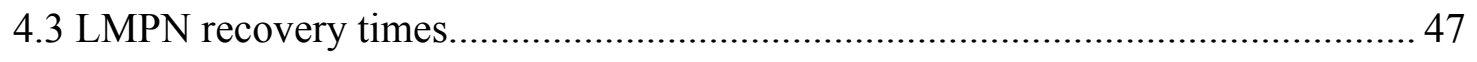

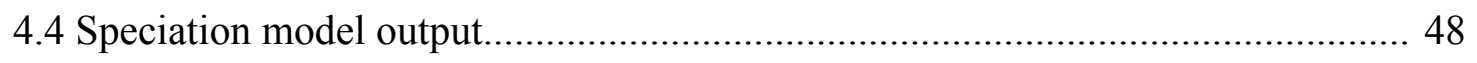

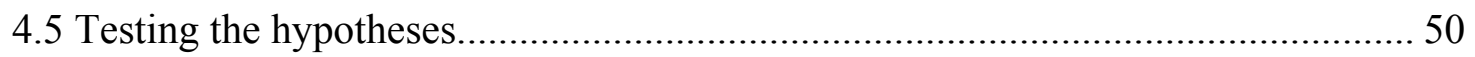

Chapter 5

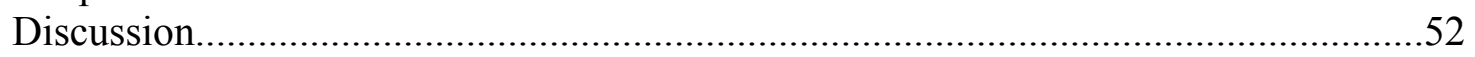

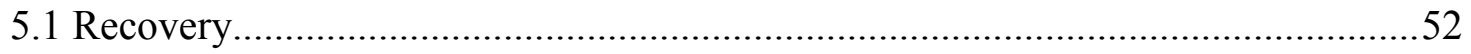

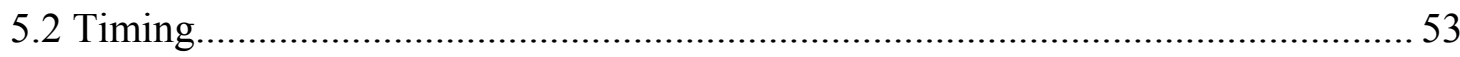

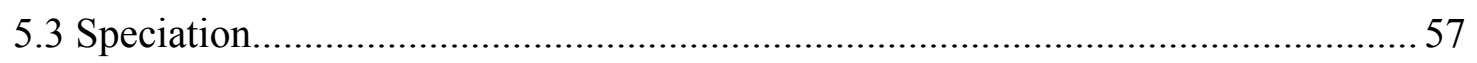

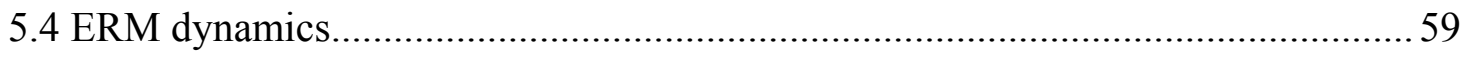

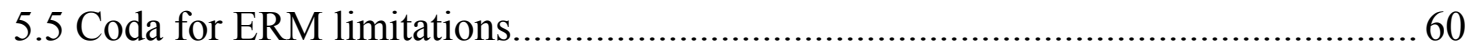

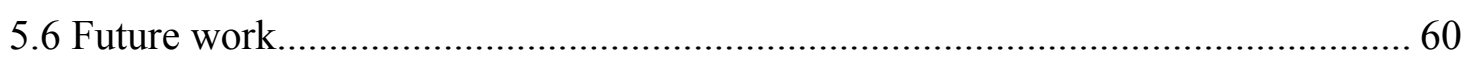

Chapter 6

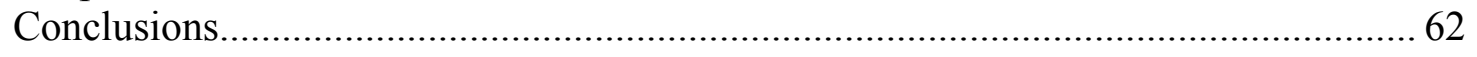

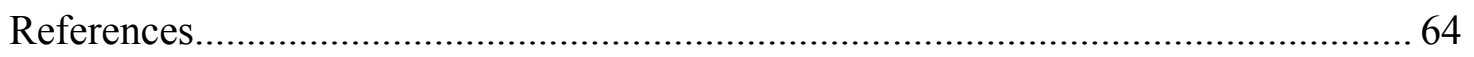

Appendices

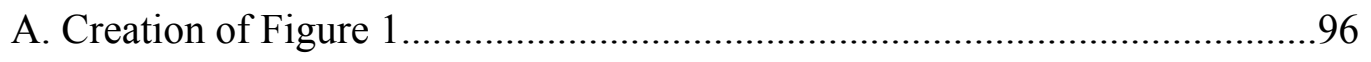

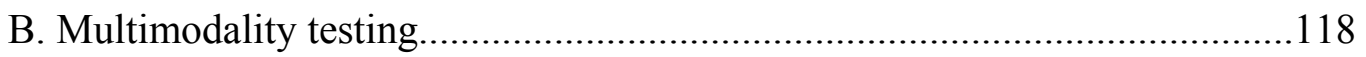

C. Potential barriers and cooridors to migration and gene flow in the late Miocene

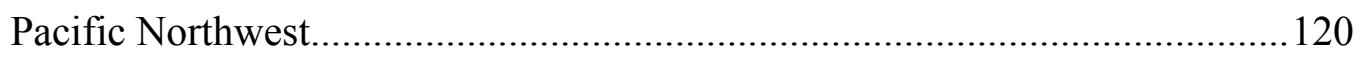

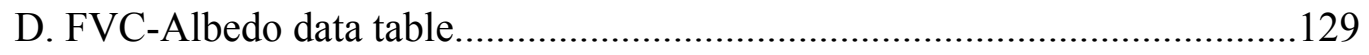

E. AE-MAP regression data table........................................................... 130 
Table 1. LMPN ash-flow characteristics............................................................... 15

Table 2. LMPN climate data............................................................................... 18

Table 3. Parameters in the ERM............................................................................ 33

Table 4. Equations in the ERM.............................................................................. 34

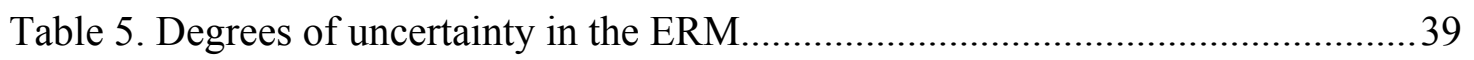

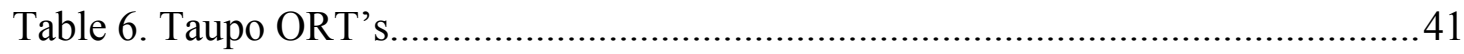

Table 7. Validation of ERM output with Taupo ORT's..........................................46

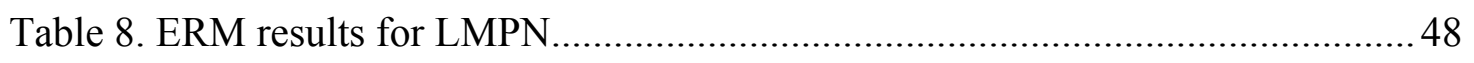

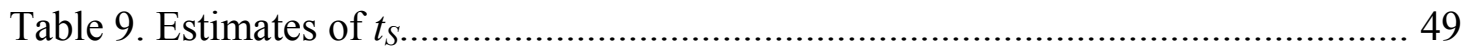

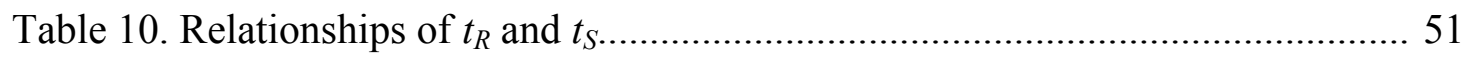

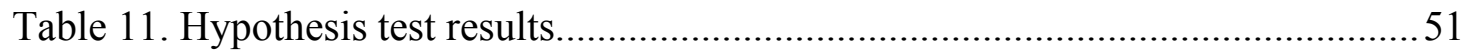

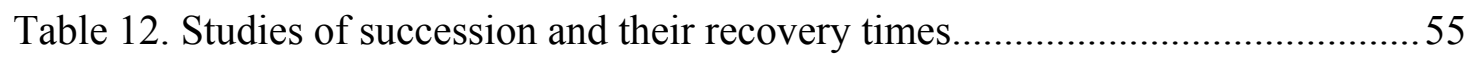


Figure 1. RST-Serengeti NP size comparison.......................................................

Figure 2. Cenozoic PNW fossil mammal temporal ranges......................................... 8

Figure 3. Fossil mammal collection area........................................................ 9

Figure 4. Mammalian body mass frequency distributions...................................... 12

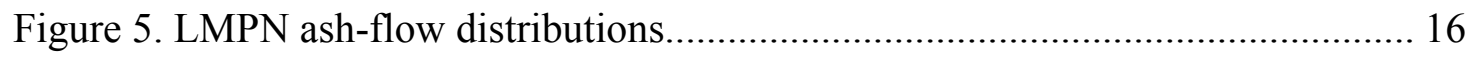

Figure 6. Conceptual illustration of hypotheses.............................................. 21

Figure 7. Cartoon of LMPN speciation-ash-flow scenario..................................... 23

Figure 8. Model flow of ERM............................................................................. 38

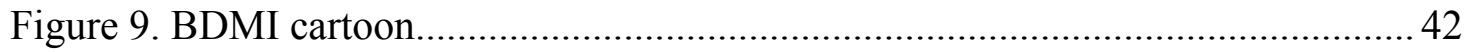

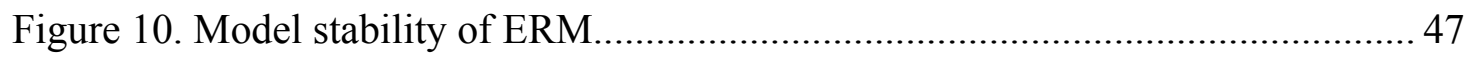

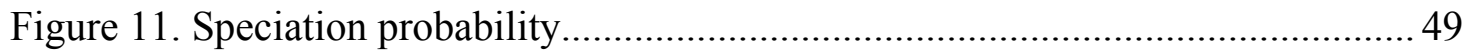

Figure 12. Comparison of time scales.............................................................. 50 
Acronyms

\begin{tabular}{|c|c|c|}
\hline $\mathrm{AE}$ & - & Actual Evapotranspiration \\
\hline AGCM/ML & - & $\begin{array}{l}\text { Atmospheric General Circulation Model/Mixed Layer } \\
\text { model }\end{array}$ \\
\hline AWL & - & Abundant, Widespread, and Long-lived \\
\hline BDMI & - & Bateson-Dobzhansky-Muller Incompatibilities \\
\hline CLAMP & - & Climate-leaf Analysis Multivariate Program \\
\hline CPER & - & Central Plains Experimental Range \\
\hline $\mathrm{DvCT}$ & - & Devine Canyon Tuff \\
\hline ERM & - & Ecosystem Recovery Model \\
\hline $\mathrm{FVC}$ & - & Fractional Vegetation Cover \\
\hline GEM & - & General Ecological Model \\
\hline LMPN & - & Late Miocene Pacific Northwest \\
\hline MAP & - & Mean Annual Precipitation \\
\hline MAT & - & Mean Annual Temperature \\
\hline MRT & - & Model Recovery Time \\
\hline NAAP & - & Net Annual Aboveground Primary Productivity \\
\hline NAFMSD & - & North American Fossil Systematics Database \\
\hline ORT & - & Observed Recovery Time \\
\hline PCT & - & Prater Creek Tuff \\
\hline PNW & - & Pacific Northwest \\
\hline RST & - & Rattlesnake Tuff \\
\hline SLOH & - & Sleep-or-Hide \\
\hline
\end{tabular}


Chapter 1

Introduction

"The slow changes of a million years of evolutionary time must yield to the rapidly fluctuating requirements of ecological time."

-Stephen J. Gould, 1977

Large-scale ash-flow eruptions deposit massive quantities $\left(10^{13}-10^{15} \mathrm{~kg}\right)$ of volcanic ash, pumice, and lithics across extensive areas $\left(10^{4} \mathrm{~km}^{2}\right)$ over short periods of time $\left(10^{3}-10^{5} \mathrm{~s}\right.$; Bursik and Woods, 1996). These flows rapidly and severely disrupt everything they contact on the ground surface. The disruption of geological surficial processes (Manville, 2000), geomorphological features (e.g. in-filled valleys), and climate (Rampino and Self, 1992, 1993; Jones et al., 2007; Cathers et al., 2010) demonstrate this power. As for scale, the Rattlesnake Tuff (RST; Streck and Grunder, $1995)$ - a high temperature $\left(\sim 860^{\circ} \mathrm{C}\right.$ pre-eruptive temperature; Streck and Grunder, 2008$)$ ash-flow tuff in central Oregon — was most likely deposited 1) in no more than a day and 2) over more than $40,000 \mathrm{~km}^{2}$. In comparison, the ecological unit for the migrating herds of the Serengeti-a roughly flat, west-sloping plateau-is approximately $25,500 \mathrm{~km}^{2}$ (Schaller, 1972; Figure 1). Given this potential for widespread disruption, how might members of surrounding ecological communities respond: evolve with the opportunity of new found isolation or subsequent equitable acreage, or simply resume their roles after the interruption? 


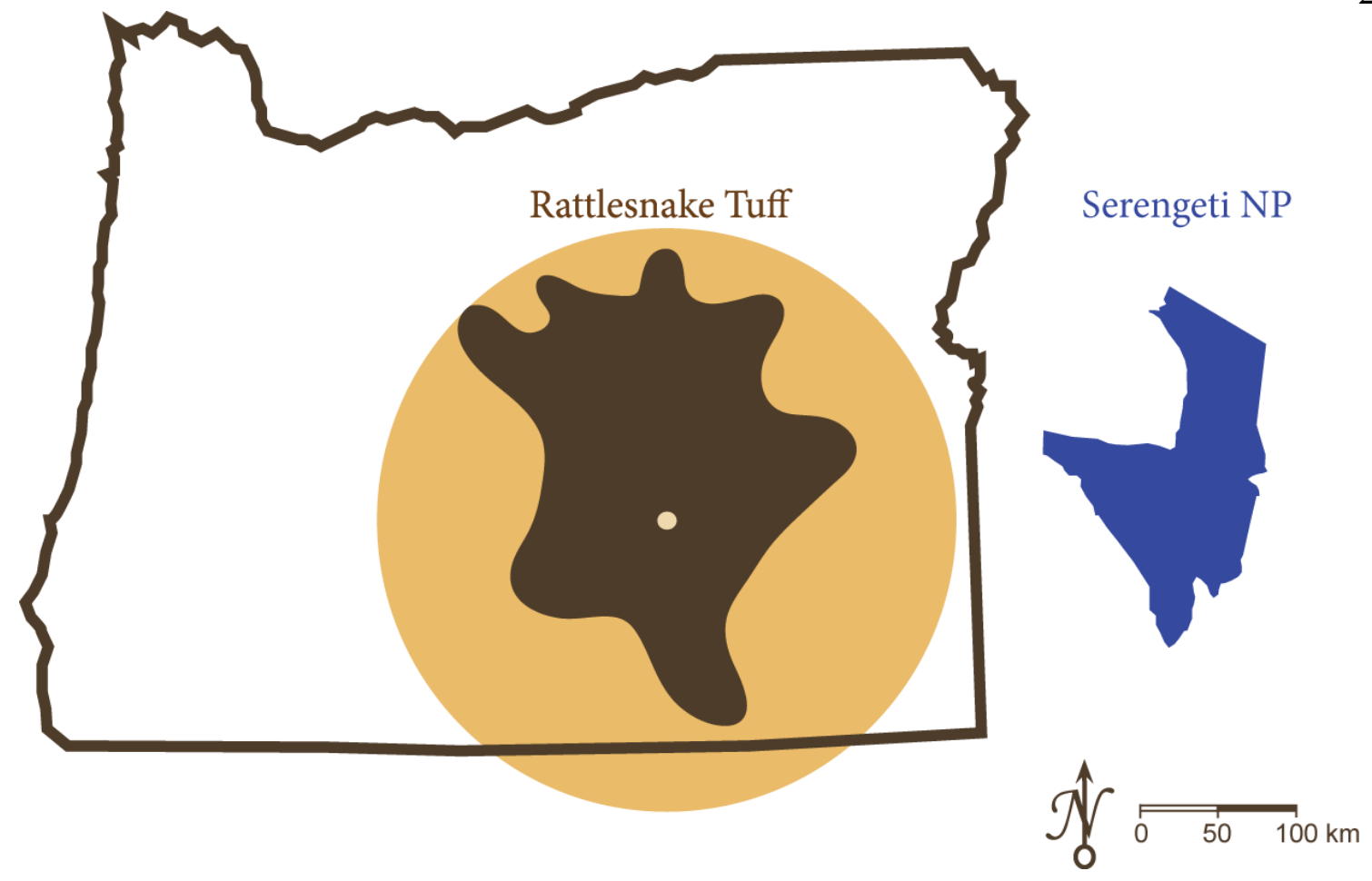

Figure 1. Comparison between areal extents of the RST in central Oregon (brown) and Serengeti National Park in Tanzania (blue). The yellow circular area is a hypothetical total area covered by the RST eruption. The white dot represents the proposed source of the RST.

\subsection{Specification of methodologies}

Ecological modeling is performed in this study to assist in the investigation of potential speciation in mammals following vast, late Miocene volcanic interruptions in the Pacific Northwest. This is done because the resolution of both the local and global fossil records are "generally too coarse in temporal scale and too limited in geographic coverage to provide a detailed history of speciation events (Erwin and Anstey, 1995)." No data on repeated fossil mammal originations in the Pacific Northwest exist immediately following large ash-flows like the RST because of scarcity of fossils in collections or a lack of stratigraphic and temporal control in these terrestrial systems. 
Moreover, adequate details to distinguish speciation or ecosystem recovery times in these stratigraphic sections are not available.

Unfortunately, one relatively simple preexisting model that uses general theory and observations around primary succession phenomena (e.g., root competition, albedo effects of volcanic ash surfaces on climate) with the goal of understanding the timing of ecosystem recovery is not available, and so had to be created. With a deficiency in data from the stratigraphic and fossil record of the late Miocene Pacific Northwest (LMPN), models that require specific parameters, variables, or interactions (e.g. nitrogen concentrations, species composition, forest population dynamics, transition probabilities, groundwater hydrogeology, etc.) that cannot be accounted for in order to produce the appropriate output are not used. Models such as the resource-ratio hypothesis (Tilman, 1985), JABORA/FORET forest simulation model (Huston and Smith, 1987), Markov models (Gibson et al., 1997, Childress et al., 1998), and general ecological models (Fitz et al., 1996) fall into this category. Thus, for example, with no known estimates for nitrogen levels in ancient soils and ash-flow surfaces of the LMPN, models that require nitrogen input were not used.

The model generated for this thesis is a cellular automaton (CA). This discrete model uses stochastic, non-agent, rule-based algorithms with different "states" (e.g. "on" vs. “off”) and allometric relationships for generating output regarding ecosystem recovery times of net annual aboveground primary productivity $\left(\mathrm{g} \mathrm{m}^{-2}\right)$ and large mammalian herbivore biomass $\left(\mathrm{g} \mathrm{m}^{-2}\right)$. Recovery time results of this ecosystem model are compared to timing in speciation probability from models developed by Orr (1995) and 
Orr and Turreli (2001) of allopatric speciation from complex hybrid incompatibilities.

These models are described in Sections 3.3.1 and 3.5, respectively. 
Chapter 2

Patterns, processes, and hypotheses

The following chapter describes the patterns and processes involved in understanding the background to the ash-flow-speciation relationship investigated in this study. It is subdivided into sections regarding biotic patterns (i.e. diversity in the fossil record, preservation of organic materials, and body mass distributions) and abiotic patterns (i.e. depositional extents of ash-flows, paleotopography, and climate), as well as biotic processes (i.e. isolation of populations and interactions in species population parameters: abundance, distribution, and lifespan). Much of the work has been summarized from the literature with the exception of new syntheses I have generated to further enrich the reader's understanding of the patterns and processes (i.e. Figure 2, Figures 4A-C, and multimodality tests in Section 2.1.3). Additionally, a premise and hypotheses are formulated.

Primary interest in this report concerns whether or not radial sheet pyroclastic flows act as an adequate barrier to gene flow within and among species populations to impose the evolution and establishment of Mayr's peripheral (1963) or secondary (2001) isolates (observed, in this case, as new species suddenly appearing in the fossil record). Neodarwinian genetics suggests species evolve as microevolutionary processes produce gradual changes predominantly through natural selection on mutation and adaptation (Coyne and Orr, 2004) while macroevolutionary patterns in the fossil record most frequently document rapid appearances in species followed by long periods of evolutionary stasis - a pattern best known as punctuated equilibrium (Eldredge and Gould, 1972; Gould and Eldredge, 1993; Gould, 2002). Moreover, Gutschick and 
BassiriRad (2003, 2010) consider extreme events, like disturbance, an integral and common ingredient for evolution while Grime (1973), Horn (1975), and Connell (1978) suggest intermediate levels of disturbance maintain the highest species diversity.

In the fossil record of the Pacific Northwest (PNW), it is difficult to discern an eruption-speciation relationship from fossil remains alone. Firstly, some strata record changing and oscillating environments and faunas interbedded with volcanic deposits (Retallack et al., 2004). Secondly, many volcanic eruptions, in part, are responsible for the preservation of the underlying basins where fossil remains are found and consequently, disrupt any apparent pattern. For example, the Rattlesnake local fauna of the late Miocene fanglomerates and paleosols west of Dayville, Oregon documents one such instance where only fragments of the mammalian assemblage (as well as similar paleosol characteristics) resume locally above the previously mentioned RST (Merriam et al., 1925; Retallack et al., 2002; T. Fremd, pers. comm., 2007). Generally, where the RST is found it is the uppermost horizon. Furthermore, highly fossiliferous terrestrially-born sediments are generally few and far between.

\subsection{The biotic patterns}

The pattern of mammalian diversity in the PNW fossil record through the last 45 million years (Figure 2) is generated from database faunal lists in the Paleobiology Database's North American Fossil Mammal Systematics Database (NAFMSD). Fossil mammal, time-range data were collected from the NAFMSD that originally came from localities within a 400-km radius centered on the proposed source area of the RST near Capehart Lake, Oregon (Streck and Grunder, 1995; Figure 3). Figure 2 illustrates non- 
volant, non-aquatic, terrestrial, fossil eutherian (placental) mammals of the PNW through time (see Appendix A for details on the collection of the data and creation of Figure 2). Twelve relatively large volcanic eruptions (vertical dashed lines) overlay the taxon ranges (horizontal solid lines). Care must be taken in the interpretation of data in Figure 2. First, taxon temporal ranges are likely to be less than their true duration (Foote and Raup, 1996). Second, temporal ranges of the taxa are based solely on occurrences within temporally determined geologic formations. 


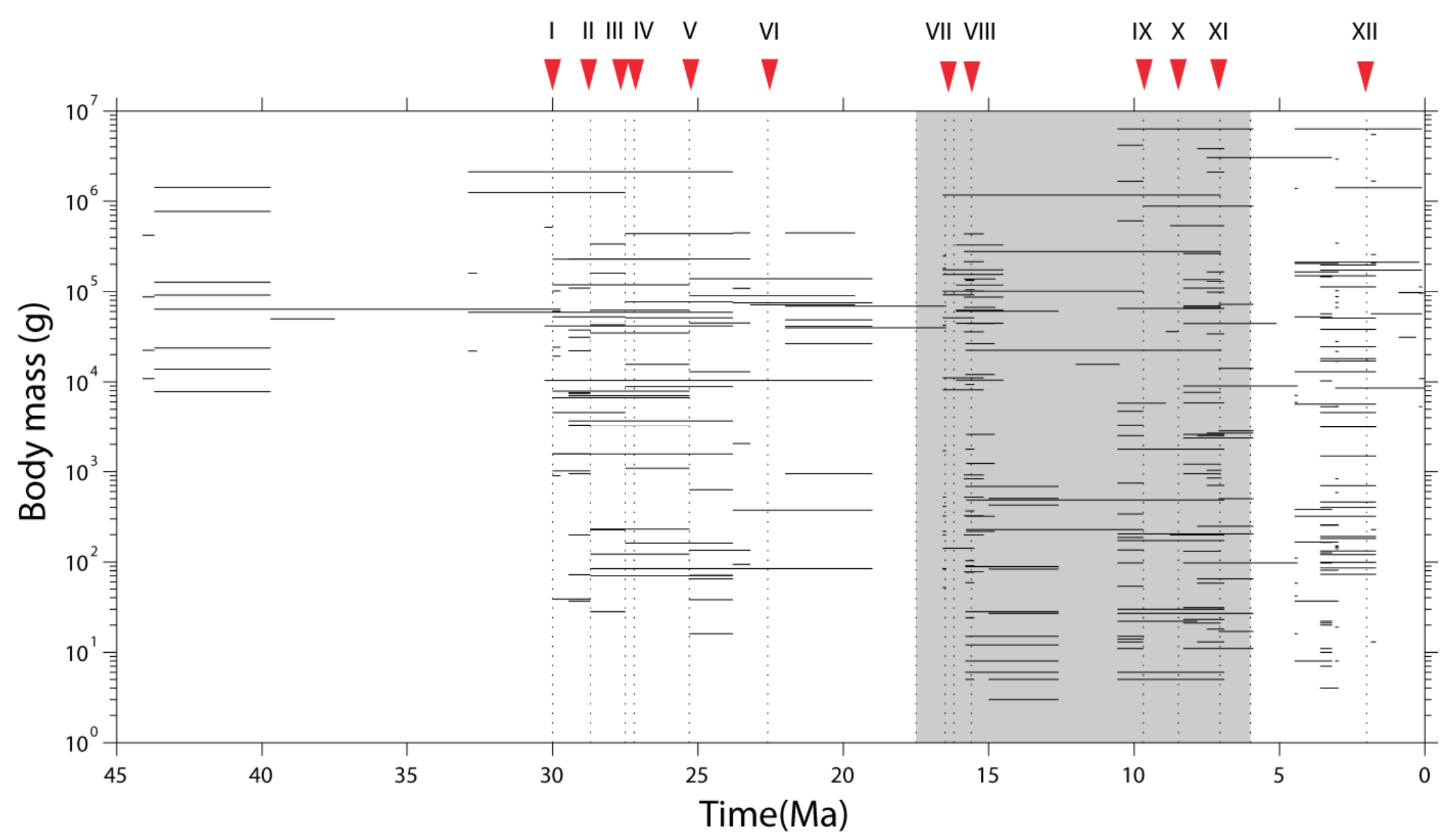

Figure 2. Temporal ranges of eutherian mammals in the Cenozoic Pacific Northwest (horizontal lines). Vertical lines indicate specific volcanic eruptions. The grey block is the period of eruption of the Columbia River Basalt Group (Camp and Ross, 2004). I) A/B Tuff (30 Ma); II) Picture Gorge Ignimbrite (28.7 Ma); III) Deep Creek Tuff (27.5 Ma); IV) Biotite Tuff (27.2 Ma); V) Tin Roof Tuff (25.3 Ma); VI) ATR Tuff (22.6 Ma); VII) Grand Ronde Basalt (16 Ma); VIII) Mascall Tuff (15.8 Ma); IX) Devine Canyon Tuff (9.68 Ma); X) Prater Creek Tuff (8.48 Ma); XI) Rattlesnake Tuff (7.05 Ma); XII) Huckleberry Ridge Tuff (2 Ma). 


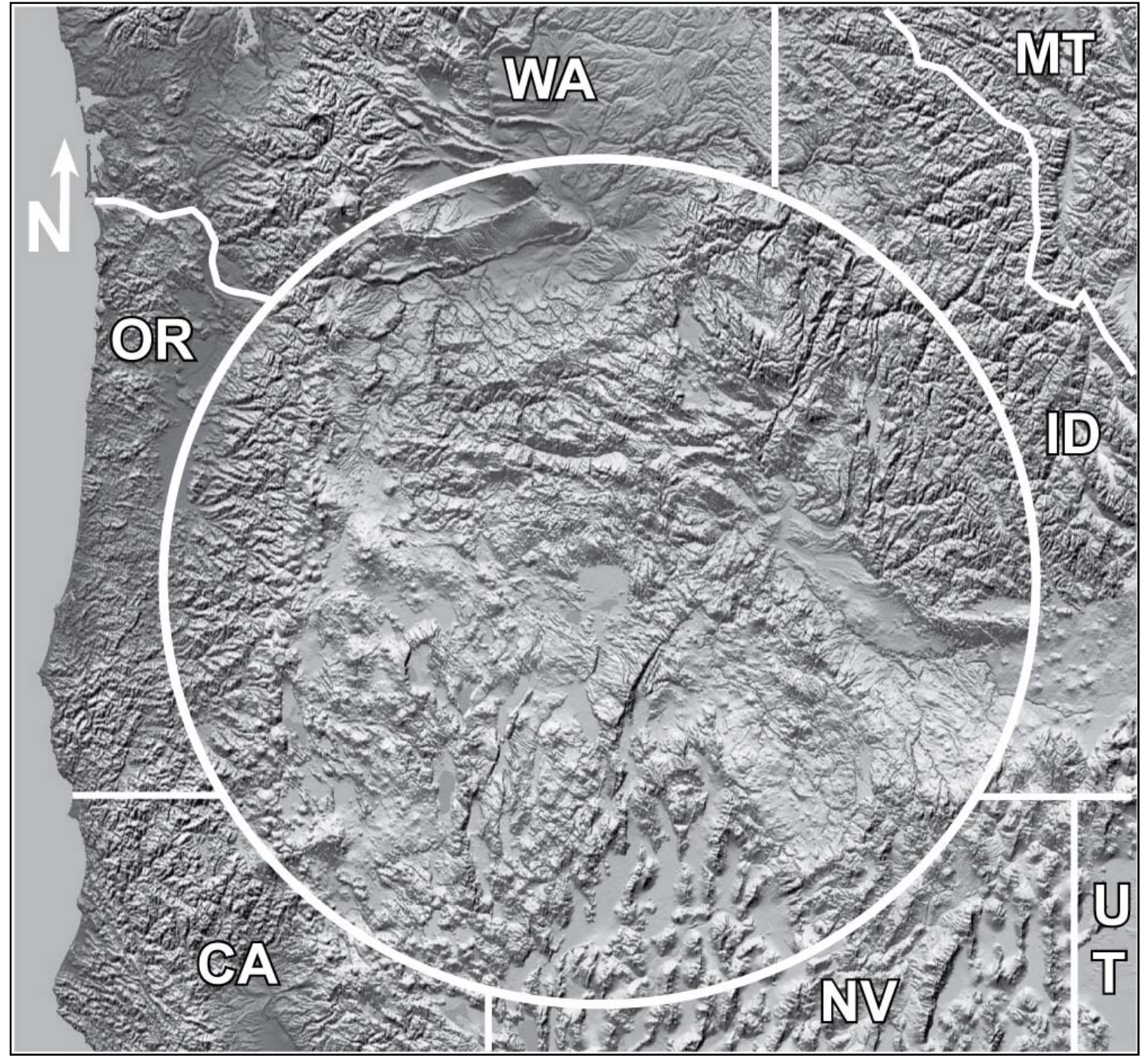

Figure 3. Shaded relief image of the PNW The area of fossil mammal collection is indicated by the white circle $\left(\sim 500,000 \mathrm{~km}^{2}\right)$ and description in Section 2.1 .

\subsubsection{Abundant, widespread, and long-lived species}

Abundant, widespread, and long-lived (AWL) species are most freqently preserved in the fossil record (Bennett, 1990; Foote and Raup, 1996; Barnosky, 2001; Vrba and DeGusta, 2004). From a statistical standpoint, this is known as length-biased sampling (Solow and Smith, 1997). AWL species tend to be overrepresented in the fossil record while rare species are likely never preserved. Spatial and temporal considerations 
regarding preservation probability and genetic drift also indirectly assume newly evolved species begin as relatively small peripherally or secondarily isolated local "founder" populations. There are tests in the fossil record to support this (Vrba and DeGusta, 2004; Millien, 2006) and tests in genetic laboratories to oppose it (Rundle et al., 1998; Rundle, 2003).

\subsubsection{Preservation of new species}

Preservation of newly evolved mammal species will likely be from the bones of large mammals. Preferential preservation of large mammals over small mammals is favored by two main modes of destruction. Behrensmeyer et al. (1979) argue that a greater degree of trampling, predation, and scavenging destroy small bones more frequently due to lower tissue density of small skeletal elements. Retallack (1988), however, argues for a stronger chemical durability of large bones due to their lower surface area to volume ratios against the effects of acidic dissolution. Both modes of destruction are likely occuring to some extent simultaneously at any given time. A discussion on preservation modes is synthesized in Lyman (1994; but also see Behrensmeyer et al., 2000).

\subsubsection{Modality in eutherian body mass distributions}

Considering preservation biases in favor of large mammals, body size frequency distributions appear to indicate a roughly inverse relationship to diversity (Figure 4A). This would suggest that new species produced by large eruptions are small-sized mammals in small, isolated populations, and thus, less likely to be preserved compared to 
large mammals. Figure 4A illustrates a unimodal body mass distribution in non-volant, non-aquatic, terrestrial eutherian mammals of late Quaternary North America $(\sim 50,000$ years to Present). Brown and Nicoletto (1991) explain this unimodal pattern to be the result of higher speciation rates and diversity at approximately $100 \mathrm{~g}$ (4 to $5 \ln \mathrm{g}$ units). When they compared eutherian species across space in present-day North American biomes (i.e. grasslands, taiga, eastern forest), the result is species in the $100 \mathrm{~g}$ size range differ across space within the same biomes, while the smallest and largest species tend to be alike. This unimodal trend has been shown to exist on other continents (e.g. Africa and South America; see Lyons et al., 2004) as well as in biogeographic zones (e.g. the Nearctic and Afrotropics; see Lovegrove and Haines, 2004). Modern 100 g-sized mammals have relatively low preservation probabilities and are not widespread, while concurrently most diverse. These general and relatively uniform results have led to the suggestion of an optimal body size of $\sim 100 \mathrm{~g}$ in terrestrial mammals (Brown et al., 1993; Brown, 1995; Chown and Gaston, 1997; Johst and Brandl, 1997; Alroy, 1998, 2003; Marquet and Taper, 1998; Gardezi and de Silva, 1999; Lovegrove and Haines, 2004). One hundred grams is also close to the average size of Cretaceous mammals (Alroy, 1998). 

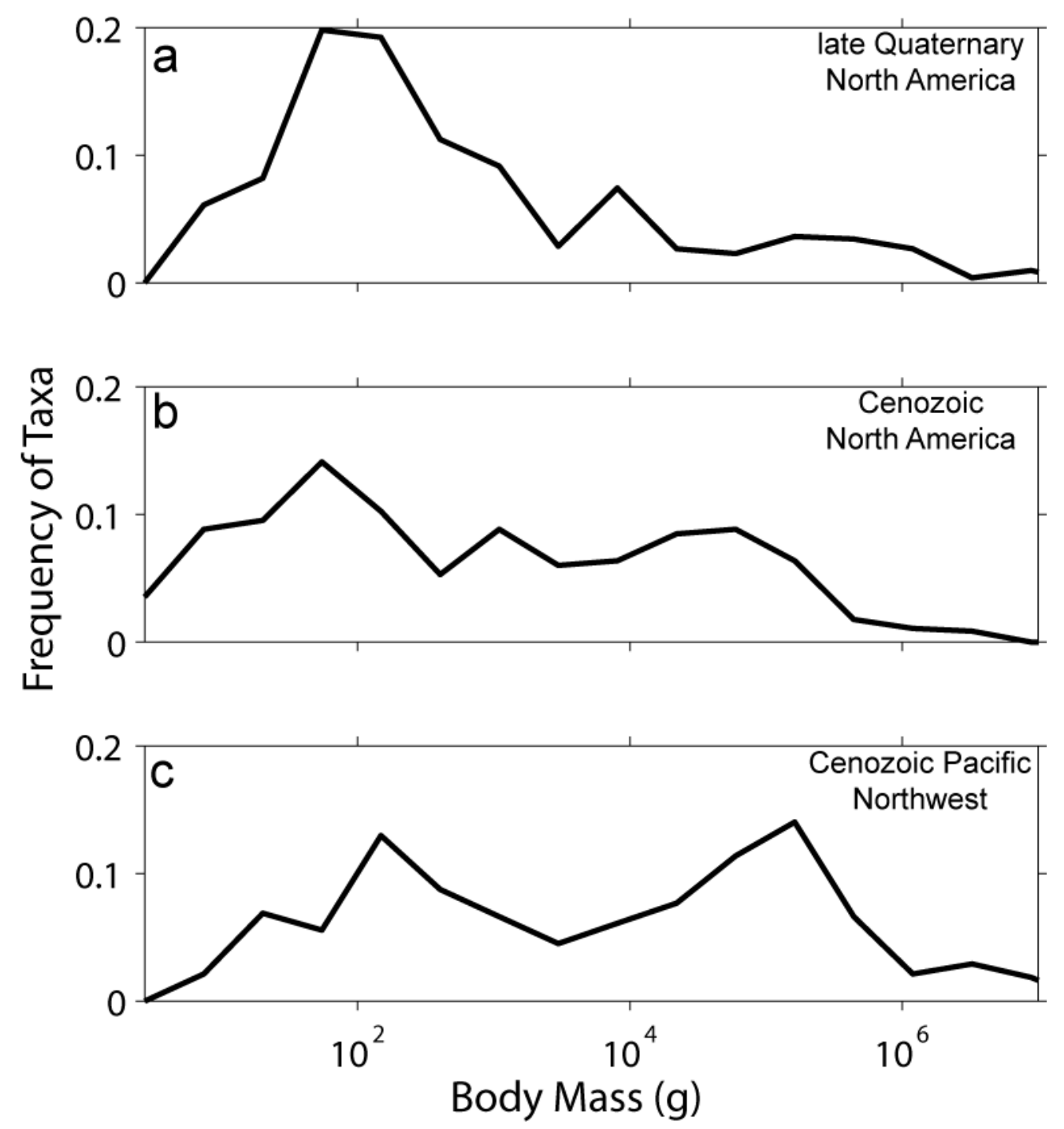

Figure 4a-c. Frequency distributions relative to body mass of a) late Quaternary North American mammals, b) Cenozoic North American mammals, and c) Cenozoic North American Pacific Northwest mammals. Modality in the late Quaternary distribution is unimodal while the distributions for Cenozoic North America and Cenozoic Pacific Northwest are bimodal. Data for the late Quaternary is from Smith et al. (2003). Data for the Cenozoic North America is adapted from Alroy (1998). Data for Cenozoic Pacific Northwest is gathered in this study and described in Appendix C. Explanations and discussion of these distribution patterns can be found in the text.

The paleontological record suggests a more bimodal pattern in body mass distributions (Alroy et al., 1998, 2003) than the late Quaternary record. This is demonstrated in the fossil record of valid North American fossil mammals in Figure 4B 
(duration of time unknown, but as a possible minimum representing the entire Cenozoic Era - the past $65 \mathrm{Ma}$ ). Several explanations have been put forward regarding the pattern. The first explanation is a pattern itself known as Cope's Rule, wherein taxaand more specifically, lineages - increase non-randomly in size over time. E.D. Cope (1887) was the first to suggest this pattern after analyzing North American Paleocene faunas. Much later, the first in-depth quantitative study confirmed the pattern for fossil mammals of North America (Alroy, 1998). No underlying cause for the pattern described by Cope's Rule was given in this report, except for the suggestion that a second unstable optimal size limit exists in mammals which perhaps has yet to become predictable. Three more explanations are introduced below. Potential explanations for the second emergent, but unstable mode are 1) low speciation rates, high extinction rates, or both (Alroy, 1998); 2) locomotory adaptations for speed (i.e. digitigrade and unguligrade from plantigrade) inadvertently increased the size of terrestrially-bound mammals (Lovegrove and Haines, 2003; however, initial tests of this explanation have not been universally positive); 3) large mammals are vulnerable to extinction via intense environmental changes while smaller mammals typically exhibit hibernation, torpor, or burrowing behaviors which act as an environmental buffer termed "sleep-or-hide" (SLOH) behavior (Liow et al., 2008).

The dual-optima of eutherian body mass modes are clear in the Cenozoic PNW (Figure 4C). Probability of multimodality for this data set is 0.95 indicating strong bimodality (Silverman, 1981; Jones, 1983; see Appendix B for details into test methodology). The result is congruent with Lovegrove and Haines' (2003) suggestion 
that subregional scales provide surplus structural detail in body mass distributions over scales larger than zoogeographical scales (i.e. continents).

\subsection{The abiotic patterns}

The abiotic patterns in the LMPN are divided into descriptions of three large-scale ash-flow tuffs, its paleotopography, and its climate. These three sections illustrate the general environmental background of the LMPN and the logic for assumptions made in the modeling to come.

\subsubsection{Three large-scale LMPN ash-flow tuffs}

Three spatially extensive ash-flow tuffs stand out in the landscape and stratigraphy of central Oregon: the Devine Canyon Tuff, Prater Creek Tuff, and previously mentioned Rattlesnake Tuff (Figure 5). Table 1 lists important features of the three tuffs. All three tuffs have devitrified and welded portions indicating very high temperatures upon eruption (Greene, 1973; Walker, 1979; Streck and Grunder, 1995). Maximum thicknesses range up to and greater than 30 meters. Rocks in outcrop above and below each of these tuffs include lacustrine, fluvial, alluvial, and volcanic deposits, though the RST tends to have sparsely preserved overlying rocks with one particular exception being the John Day Valley. Formations comprising and adjacent to these tuffs are in Table A.2 in Appendix A. 
Table 1. Some important features of three large-scale ash-flow tuffs in central Oregon erupted over a period in the LMPN from 10-7 Ma.

\begin{tabular}{|c|c|c|c|c|}
\hline Tuff & Age & Original Area & Source & Age Reference \\
\hline Rattlesnake Tuff (RST) & $\begin{array}{l}7.05+/- \\
0.01 \mathrm{Ma}\end{array}$ & $\begin{array}{c}50,000 \mathrm{~km}^{2} \\
\text { Walker, } 1979\end{array}$ & $\begin{array}{c}\text { Capehart } \\
\text { Lake, western } \\
\text { Harney Basin }\end{array}$ & $\begin{array}{c}\text { Streck and } \\
\text { Grunder, } 1995\end{array}$ \\
\hline Prater Creek Tuff (PCT) & $\begin{array}{l}8.48+/- \\
0.05 \mathrm{Ma}\end{array}$ & not estimated & undetermined & $\begin{array}{c}\text { Dieno and } \\
\text { Grunder, unpub. }\end{array}$ \\
\hline $\begin{array}{c}\text { Devine Canyon Tuff } \\
\text { (DvCT) }\end{array}$ & $\begin{array}{l}9.68+/- \\
0.03 \mathrm{Ma}\end{array}$ & $\begin{array}{c}>18,600 \mathrm{~km}^{2} \\
\text { Streck and Ferns, } \\
2004\end{array}$ & Harney Basin & $\begin{array}{c}\text { Dieno and } \\
\text { Grunder, unpub. }\end{array}$ \\
\hline
\end{tabular}

\subsubsection{Terrain and relief in the LMPN}

The RST is relatively uniform in thickness typically $15-30 \mathrm{~m}$ thick with greatest and least thicknesses at approximately 70 and $5 \mathrm{~m}$, respectively. Interpretation inferred from this range in thickness is that of a low relief landscape at the time of the eruption. This is supported by a large number of nearly complete sections (recording multiple welding facies) throughout most of the outcrop area. According to Streck and Grunder (1995), a "more rugged topography would have generated thicker valley deposits thinning outward with a more patchy distribution pattern," while Streck and Grunder (2007) note that the RST is "among the farthest traveled pyroclastic flows currently known." Ash fall from the Rattlesnake Tuff eruption very likely was deposited as far south as northern Nevada in the Thousand Creek Formation. According to Perkins et al. (1998), ash collected in the Thousand Creek Formation "is an excellent match to basal fallout tuff we collected from the 7.05 Ma Rattlesnake Tuff...in the Harney Basin, Oregon." Unlike the RST, less about the thickness uniformity of the PCT and DvCT is known regarding the topographic relief present at the time of deposition. However, 
thicknesses between 10 and $20 \mathrm{~m}$ are found in 54\% of Greene's (1973) measured

DvCT sections $(\mathrm{n}=28)$. The DvCT's area is perhaps comparable to the Taupo Ignimbrite on the North Island of New Zealand $\left(\right.$ area $=20,000 \mathrm{~km}^{2}$ ). Figure 5 illustrates the areas of general outcrop extent from mapping for the three tuffs.

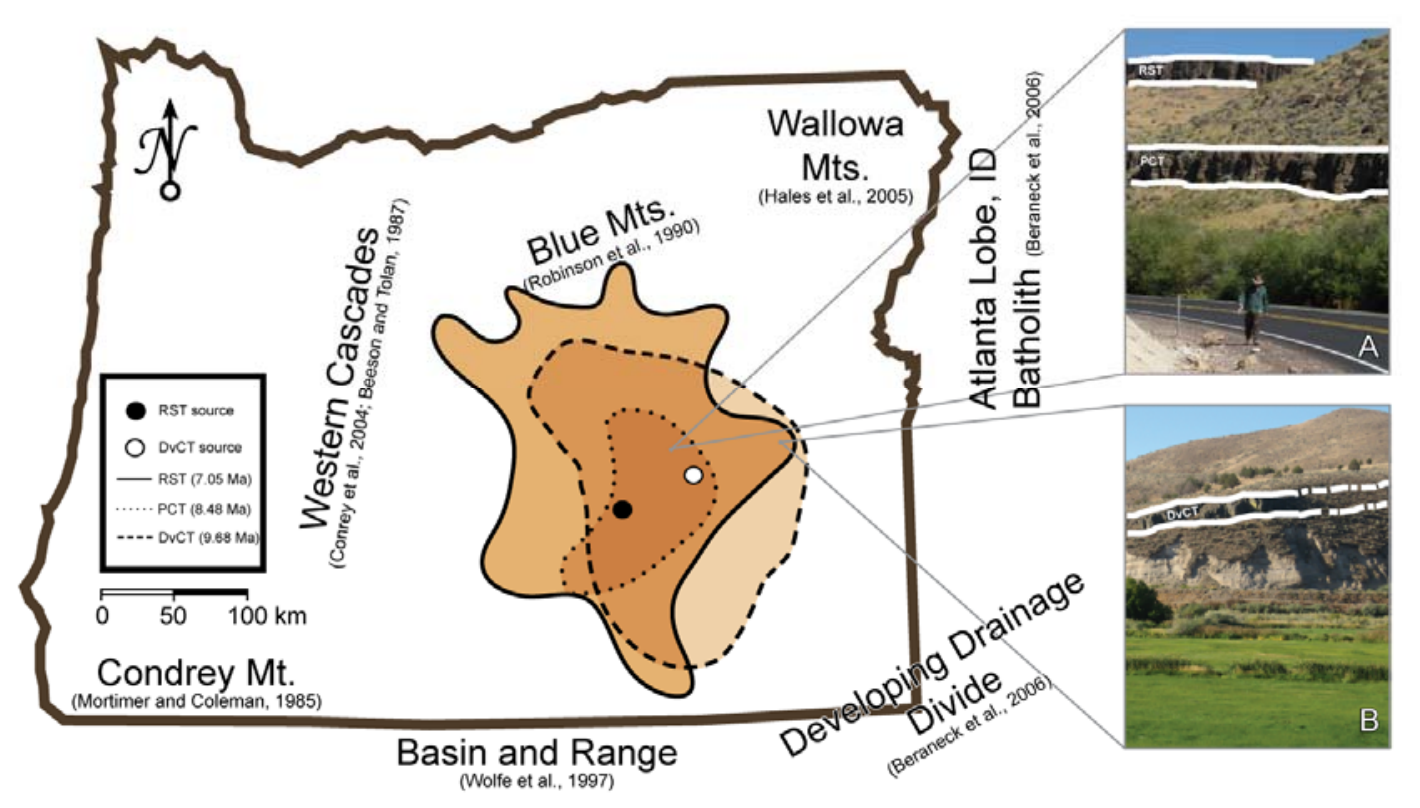

Figure 5. Areal extent of Devine Canyon Tuff (DvCT), Prater Creek Tuff (PCT), and Rattlesnake Tuff (RST; 30,000-40,000 $\mathrm{km}^{2}$ ) amidst regions of high elevation throughout the time spanning the eruptions (10-7 Ma). Images A and B hail from central and eastern Oregon, respectively. Image A is from the Devine Canyon on Highway 395. Upper tuff is the RST and the lower tuff is the PCT. Image B is an image of the DvCT near Juntura viewed from the road to Chucker Campground. Modified from Streck and Ferns (2004).

Topographic barriers noted by Streck and Grunder (1995) are the Strawberry and Aldrich Mountains. However, multiple topographic features potentially acting as migration barriers may have been present between 10-7 Ma (Figure 5). Appendix C describes much of the elevation, fluvial, and basinal features understood to be present in the LMPN. 


\subsubsection{LMPN climate}

Atmospheric circulation patterns constructed using an atmospheric general circulation model and a mixed layer ocean model (AGCM/ML) for the late Miocene indicate western North America experienced similar climate conditions and changes with the seasons to today (Steppuhn et al., 2006). Steppuhn et al. (2006) report the atmospheric circulation over the Pacific Ocean to be in a permanent El Niño state. Model reconstructions of the paleoclimate are supported by terrestrial proxy data (Micheels et al., 2007; Steppuhn et al., 2007).

Local estimates of mean annual precipitation $(M A P ; \mathrm{mm} / \mathrm{yr})$ and mean annual temperature (MAT; ${ }^{\circ} \mathrm{C}$ ) in the LMPN may be made using fossil leaves and paleosols. Using his climate-leaf analysis multivariate program (CLAMP), Wolfe (1994) established estimates for MAT from fossil leaves in the middle Ellensburg Formation ( 10 Ma) in south central Washington as $12.3^{\circ} \mathrm{C}$ and in the late Miocene Troutdale Formation of Oregon west of the Cascades as $11.7^{\circ} \mathrm{C}$. Applying Wolfe's CLAMP, Buechler et al. (2007) give a MAT of $13.4^{\circ} \mathrm{C}$ from the late Miocene (10.5-8.5 Ma) Pickett Creek Flora in Owyhee County, Idaho. Buechler et al. (2007) also give a precipitation estimate of 690 $\mathrm{mm}$ for an approximately eight month growing season.

Retallack (2007) has conducted extensive studies generating estimates for MAP and MAT from paleosols spanning much of the Oligocene to Holocene of central and eastern Oregon including 104 measured and analyzed paleosols that comprise the late Miocene sub-epoch (11.608 - 5.332 Ma; Tortonian and Messinian Stages). MAP estimates from Bk horizon depths (corrected for compaction) in paleosols give an average 
range of $235-517 \mathrm{~mm} / \mathrm{yr}$ from 46 sampled horizons ( 10-7 Ma). Chemical analyses of $\mathrm{Al}_{2} \mathrm{O}_{3} /\left(\mathrm{Al}_{2} \mathrm{O}_{3}+\mathrm{CaO}+\mathrm{Na}_{2} \mathrm{O}\right)$ molar ratios yield $M A P$ estimates for six late Miocene paleosols ( $\sim 7 \mathrm{Ma})$ range on average from 521 - $885 \mathrm{~mm} / \mathrm{yr}$. Retallack (2007; North American paleosol database by Retallack) estimates MAT from chemical analyses of $\left(\mathrm{Na}_{2}+\mathrm{K}_{2} \mathrm{O}\right) / \mathrm{Al}_{2} \mathrm{O}_{3}$ molar ratios of the same six paleosols is $11.3^{\circ} \mathrm{C}$ with an average range of $6.9-15.7^{\circ} \mathrm{C}$. Table 2 summarizes the $M A P$ and MAT values for the LMPN.

Table 2. LMPN climate data from fossil leaves and paleosols. MAT collumn illustrates the range first and then the average. Note the difference in MAP values for Retallack's (2007) chemical composition and Bk horizon depth methods. The Bk horizon depth estimations are for paleosols in an adequately dry environment to form Bk (aka calcic) horizons, whereas the chemical composition estimations are made from clay deposits in wetter environments that have higher weathering rates and thus reflect higher MAP values. Additionally, the number of samples for Bk horizons is much greater than for molar ratios. NAPD is short for North American paleosol database.

\begin{tabular}{|c|c|c|c|c|c|c|}
\hline Location & $\begin{array}{c}\text { Formation/ } \\
\text { Flora }\end{array}$ & Age & MAT & MAP & Method & Reference \\
\hline $\begin{array}{l}\text { central } \\
\text { Oregon }\end{array}$ & $\begin{array}{l}\text { Rattlesnake } \\
\qquad \mathrm{Fm} .\end{array}$ & $\begin{array}{c}7.2-7 \\
\mathrm{Ma}\end{array}$ & $\begin{array}{c}6.9-15.7^{\circ} \mathrm{C} \\
11.3^{\circ} \mathrm{C}\end{array}$ & $\begin{array}{c}521-885 \\
\mathrm{~mm} / \mathrm{yr}\end{array}$ & $\begin{array}{l}\text { chemical } \\
\text { composition }\end{array}$ & $\begin{array}{c}\text { Retallack } \\
\text { (2007; } \\
\text { NAPD) }\end{array}$ \\
\hline $\begin{array}{l}\text { central } \\
\text { Oregon }\end{array}$ & $\begin{array}{l}\text { multiple } \\
\text { fms. }\end{array}$ & $\begin{array}{c}10-7 \\
\mathrm{Ma}\end{array}$ & na & $\begin{array}{c}235-517 \\
\mathrm{~mm} / \mathrm{yr}\end{array}$ & $\begin{array}{l}\text { Bk horizon } \\
\text { depth }\end{array}$ & $\begin{array}{c}\text { Retallack } \\
\text { (2007; } \\
\text { NAPD) }\end{array}$ \\
\hline $\begin{array}{c}\text { south- } \\
\text { central } \\
\text { Washington }\end{array}$ & $\begin{array}{c}\text { middle } \\
\text { Ellensburg } \\
\text { Fm. }\end{array}$ & $\sim 10 \mathrm{Ma}$ & $\begin{array}{c}4.6-20.0^{\circ} \mathrm{C} \\
12.3^{\circ} \mathrm{C}\end{array}$ & na & CLAMP & $\begin{array}{l}\text { Wolfe } \\
\text { (1994) }\end{array}$ \\
\hline $\begin{array}{l}\text { Oregon, } \\
\text { west of } \\
\text { Cascades }\end{array}$ & $\begin{array}{l}\text { Troutdale } \\
\text { Fm. }\end{array}$ & $\begin{array}{c}\text { 10 Ma } \\
?\end{array}$ & $\begin{array}{c}3.8-19.6^{\circ} \mathrm{C} \\
11.7^{\circ} \mathrm{C}\end{array}$ & na & CLAMP & $\begin{array}{l}\text { Wolfe } \\
\text { (1994) }\end{array}$ \\
\hline $\begin{array}{l}\text { Owyhee } \\
\text { Co., Idaho }\end{array}$ & $\begin{array}{c}\text { Pickett } \\
\text { Creek Flora }\end{array}$ & $\begin{array}{c}10.5- \\
8.5 \mathrm{Ma}\end{array}$ & $\begin{array}{c}2.8-24.0^{\circ} \mathrm{C} \\
13.4^{\circ} \mathrm{C}\end{array}$ & $\begin{array}{c}690 \mathrm{~mm} / 8 \\
\text { mo. } \\
\text { growing } \\
\text { season }\end{array}$ & CLAMP & $\begin{array}{c}\text { Buechler } \\
\text { et al. } \\
\text { (2007) }\end{array}$ \\
\hline
\end{tabular}




\subsection{General premise and hypotheses}

With the general LMPN biotic and abiotic patterns in mind, a general premise and hypotheses are presented below. An additional section describes circumstances regarding isolation in local populations. These sections attempt to incorporate and synthesize the general biotic and abiotic patterns and processes into a testable approach for explaining the potential for speciation.

\subsubsection{Premise}

Three propositions and a conclusion are as follows:

- Punctuated equilibria are predominantly observed in fossil taxa (Gould, 2002; Geary, 2009).

- Allopatric (dichopatric and peripatric) ${ }^{1}$ speciation is the classic mode of speciation proposed as a mechanism for the many rapid originations observed in the fossil record (Eldredge and Gould, 1972).

- Taggart and Cross (1990) describe ecological recovery and volcanic interruptions of ecosystems as "disturbance or destruction by local volcanic activity...followed by distinct seral stages, barring further disturbance, leading to the reestablishment [my emphasis] of a diverse...community mosaic."

\footnotetext{
${ }^{1}$ Dichopatric speciation (aka, vicariant allopatric speciation) is the origination of new species in isolation where a physical barrier crosses a once continuous geographic range of a species population (e.g. flooding of the Bering Strait at the end of the Pleistocene Epoch isolating Alaska and Siberia; Mayr, 2001). Peripatric speciation is the origination of new species in isolation due to dispersal of a subset of a species population to areas beyond the periphery of the species range (e.g. species dispersal to islands from mainland populations; Mayr, 2001).
} 
- Geologically instantaneous large-scale pyroclastic eruptions coupled with nearby increases in elevation or uncrossable water bodies provide adequate isolation to generate new dichopatric species before ecosystems return to their former states reuniting populations.

\subsubsection{Hypotheses}

To evaluate the premise outlined above, two hypotheses are formed; a null $\left(H_{0}\right)$ and an alternate $\left(H_{1}\right)$. The hypothesis to be tested is

$$
H_{0}: t_{R} \cong \min \left(t_{S}\right)
$$

which states that recovery time $\left(t_{R}\right)$ following large-scale eruptions is approximately equal to the minimum time for speciation $\left(t_{S}\right)$ in eutherian mammals. This is tested against the alternate

$$
H_{1}: t_{R}<\min \left(t_{S}\right)
$$

which states that $t_{R}$ following large-scale eruptions is less than $\min \left(t_{S}\right)$ in eutherian mammals (Figure 6). 


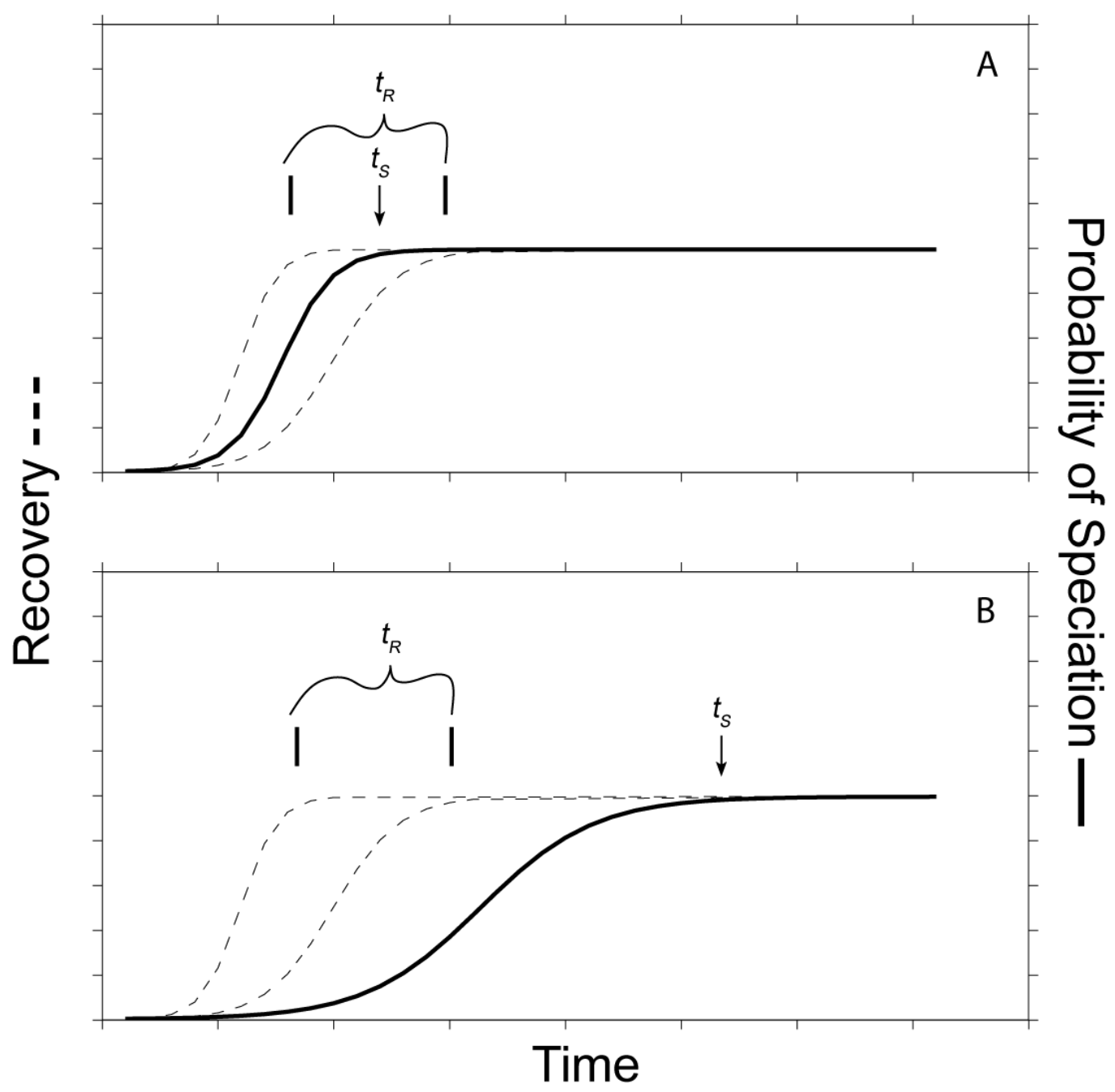

Figure 6. Conceptual illustration of the relationship between recovery time $t_{R}$ and speciation time $t_{S}$ for the A) null hypothesis $H_{0}$ and B) the alternate $H_{1}$. In (B) $H_{0}$ is rejected.

At the center of these hypotheses is the interplay between evolutionary time and ecological time. Will the relatively rapid changes and processes in ecological time intersect the slower evolutionary time scale provided by the potential evolutionary circumstances of large-scale ash-flows? Or, does $t_{R}$ encourage Futuyma (1987) and Eldredge's (2003) ephemeral "sloshing bucket" of gene pools over time? The consequences for these hypotheses are that no potential for speciation lies in the premise 
if a $t_{R}$ approximately equal to the $\min \left(t_{S}\right)$ is not met. Without having met this criterion it is unlikely large-scale pyroclastic eruptions coupled with migration barriers like nearby increases in elevation will generate new mammal species.

\subsubsection{Isolation of populations and communities}

Isolation is intended in this section to describe only the physical, geographic isolation of populations and communities; not the "isolating mechanisms" of the Modern Synthesis (Dobzhansky, 1937; Huxley, 1942; Mayr, 1942; Simpson, 1944; White, 1945; Rensch, 1947; Stebbins, 1950) and all the genetic bases for pre- and postzygotic barriers intrinsic to sexual reproduction explored thereafter. Much of what was written in Section 2.1.1 on AWL species aligns well with what follows regarding population size and distribution.

Of the four main evolutionary processes (mutation, migration, natural selection, and random genetic drift), migration is most closely related to geographic isolation. Once isolated, a population or community will no longer have access to the allelic variability of the parent population or community. A disconnected population thus is composed of vicariant populations and may potentially generate reproductively isolated allopatric species if enough time has passed for adequate genetic differentiation to arise and persist (Mayr, 1954, 1982, 2001). If a population is severely cut-off from the parent population with only a sampling of the parent population's variability, large genetic changes may occur relatively rapidly forming a dichopatric (Mayr, 2001) or peripatric (Mayr, 1982, 2001) species from the peripheral isolate. The dichopatric mode coupled with physical barriers and a large eruption is illustrated in Figure 7. 

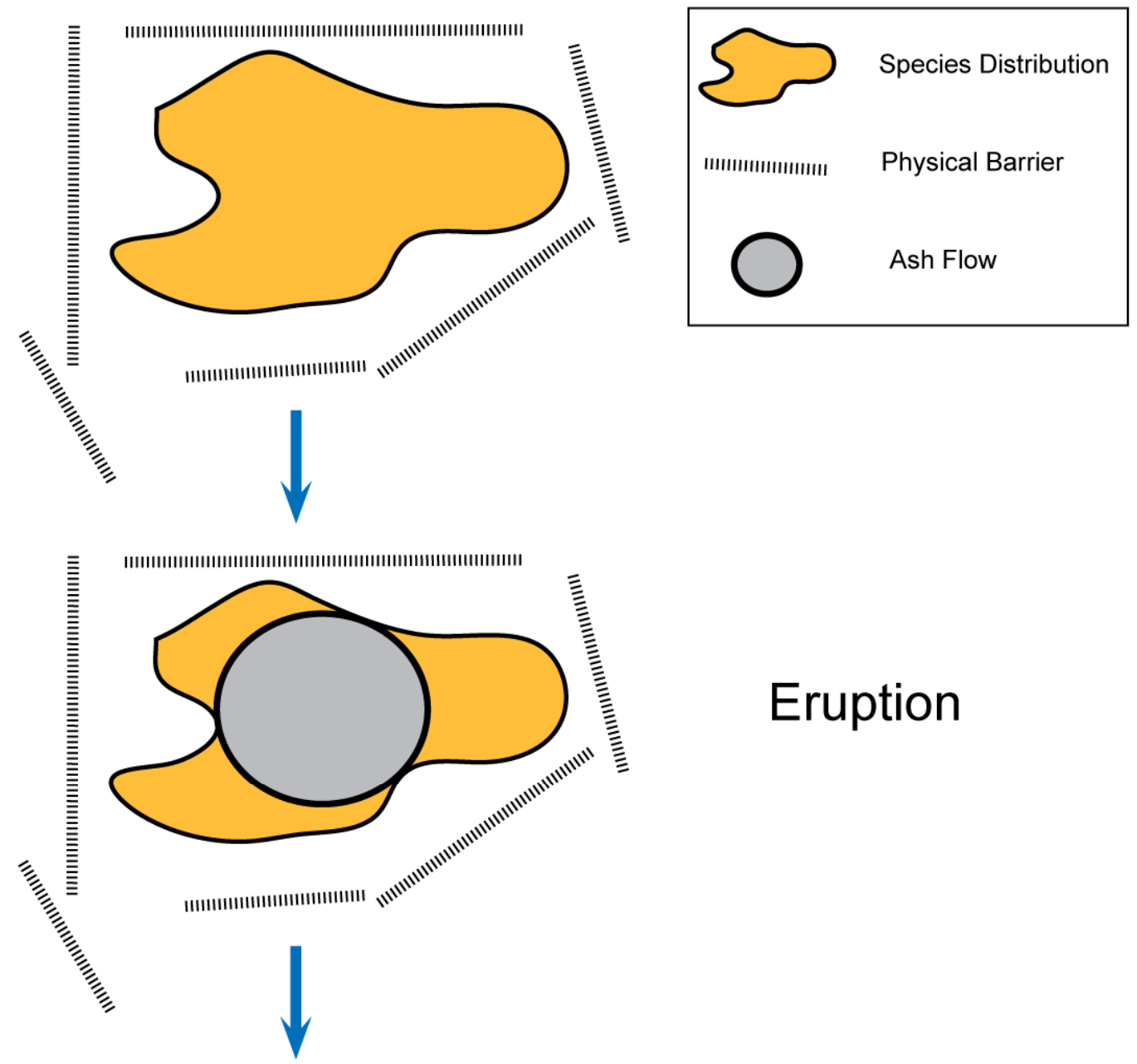

\section{Eruption}

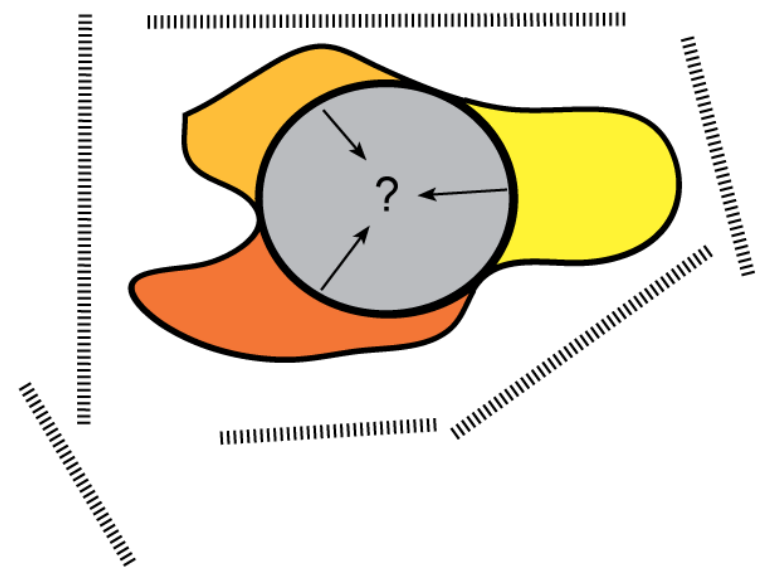

\section{Recovery}

Figure 7. Illustration of the potential effects of a large-scale ash-flow eruption coupled with nearby physical barriers like increases in elevation. Vicariant populations recover from their respective isolation. Given the populations are strongly isolated, the duration of time spent recovering the former species distribution is unknown. The fragmented populations are dichopatric. 
One example of isolation due to physical barriers concerns small mammals at high elevations in the Great Basin. In a now well-known study, Brown (1971) found that species of small mammals living in the "montane islands" of the Great Basin were isolated from each other by a "sea of sagebrush desert." These species migrated in the wetter glacial periods of the Pleistocene and became isolated during interglacials. On the largest "islands" the diversity of small mammals is unchanged from the "mainland" populations east and west of the Great Basin while the smaller "islands" have experienced extinction.

Schaller (1967) observed that habitat requirements restricted the movements of ungulates in India. In particular, barasingha (Cervus duvauceli), along with other ungulates in India, tend to avoid steep terrain. At the time of Schaller's study he noted that "another factor which has influenced the distribution of the barasingha is their avoidance of extensive steep terrain like the foothills of the Himalayas. The large grass meadows of Corbett Park have been in existence at least since 1840, but they have not been colonized, the animals having failed to venture over the one or two ridges that separate their habitat in the plains from that in the foothill valleys (1967)."

Whether surrounded by water or different environments, islands are the best examples of how changes in species arise due to isolation from parent populations; studies on the diversity of finches on the Galapagos Islands are certainly the most popularized example of peripheral isolates. Island isolation is not as "messy" as mainland isolation because constraints on temporal development and spatially distinguishable boundaries are more readily observed. Studies of biological evolution on islands exist for both modern (Lomolino, 1985, 2005; Schmidt and Jensen, 2003; Bromham and Cardillo, 
2007; Meiri et al., 2008; Losos and Ricklefs, 2009) and ancient (Lister, 1989; Millien, 2006; Raia and Meiri, 2006) settings. Generally, morphological changes are studied most (e.g. body size in the "island rule"). This appears to be valid since morphological changes are generally observed most frequently over behavior, physiology, and life history traits (Mousseau and Roff, 1987). In this study however, the key to understanding the potential duration of isolation in the "mainland" setting of the LMPN will depend on the length of time for recovery following such large ash-flows like the RST, PCT, and DvCT. This is made more apparent since examples of adequate detail on morphological change above and below these tuffs is not known. 
Chapter 3

Methods

\subsection{General overview of methods}

Three possible approaches to address the previously described ash-flowdichopatric speciation scenario in Sections 2.3.1-2.3.3 (Figure 6) are: 1) perform extensive field work to obtain collections of data from multiple deposits in outcrops above and below major ash-flows to determine any pedological, floral, and faunal changes; 2) complete rigorous analytical and statistical methods on fossil data from multiple well-defined stratigraphic sections with deposits above and below major ashflows to determine any significant trends; 3) model a process or processes associated with the scenario and apply the model to particular identified or inferred conditions. Only the third option was investigated here. It is described below taking the form of a cellular automaton (CA).

\subsection{Method and model selection}

A cellular automaton representing ancient ecosystems is considered here an appropriate model design for establishing recovery times in the LMPN. There is limited knowledge on specific details typically included in studies of modern systems for wich to apply to paleoecosystem dynamics in this study of the LMPN. Moreover, accounting for a plethora of processes involved in ecosystem interactions, responses, and patterns known in modern settings is difficult to manage in a model with regard to the relative paucity of paleoenvironmental and paleoecological data. Additionally, data with regard to the LMPN is typically coarse in spatial and temporal resolution, and therefore, such 
averaging automatically contains reductions in small-scale process variability. Inclusion of numerous processes with unknown boundaries ought to be limited in modeling short space and time scales in studies of past geologic periods. Nevertheless, there are some processes that could not be avoided including spatial and temporal inhibition and disturbance and seedling establishment rates.

Many model types exist to represent ecosystems. Such ecological model types can be viewed as roughly falling into five categories: unstructured, biologically-structured, individual-based, metapopulation, and landscape (spatially explicit) models. The following paragraphs attempt to briefly explain what these model types are and reasons for their rejection. The first three model types are generally not given spatial structure (Munns et al., 2007).

Unstructured models in ecology are generally deterministic models that describe populations in terms of abundance and density. For example, coupled Lotka-Volterra predator-prey ordinary differential equations predict predator-prey population cycles. However, beyond the laboratory these cycles are rarely observed in nature (DeRoos and Persson, 2005). Thus, they are generally deemed empirically unsuccessful by ecosystem modelers (Odenbaugh, 2005).

Biologically-structured models represent systems with ages, stages or classes. Stages can be demographic, developmental, size, or genetic. They are generally densityindependent and deterministic (Munns et al., 2007). It is possible to apply biologicallystructured models to primary succession scenarios based on intermediate stages in succession. However, this type of modeling requires data on plant abundance and 
diversity. Data of this kind are not available from the stratigraphic and fossil records of the LMPN.

Individual-based (aka agent-based or entity-based) models focus on single entities rather than groups of entities. Gap models are likely one of the most used examples of this type. With respect to primary succession, Huston and Smith (1987) applied the JABOWA/FORET forest simulation gap model to pairs of species with contrasting characteristics (e.g., shade tolerance vs. intolerance). Individual-based models like the JABOWA/FORET gap model usually require specific data on species and their characteristics. A similar model is the grassland gap model (STEPPE) of the Central Plains Experimental Range in north-central Colorado (Coffin and Lauranroth, 1990). Despite the near congruency of biomes between characteristics of the modern grassland steppe of north-central Colorado and the shrub steppe of the LMPN (e.g., mean annual precipitation ranges and vegetation types), deficiency in species-specific data regarding the shrub steppe of the LMPN stands in the way of successfully executing the STEPPE gap model. Additionally, no stipulation is made to whether the model is for primary or secondary succession. Since its initial conditions have organic soil present — and, at times, additional fertilizer from cow dung "disturbance"- - secondary succession is the likely succession type modeled. Thus, the STEPPE gap model also requires modification for application in a primary succession scenario.

Metapopulation models consider population dynamics between disjunct populations across space. These disjunct populations are segregated subunits connected by migration and can be used at both individual-based or population levels (Munns et al., 2007). There likely are some metapopulation dynamics at work in a recovering 
ecosystem $\geq 10^{3} \mathrm{~km}^{2}$ as would have existed following the ash-flow eruptions of the LMPN. However, fully developing a model on such a scale with computer software is perhaps unrealistic at this time. Ideally, for example, a primary succession model would simulate process interactions of all known species and their characteristics at the individual $\left(\mathrm{m}^{2}\right.$ ?) scale over $\geq 10^{10}\left(\mathrm{~m}^{2}\right.$ ?) cells through $\geq 10^{2}$ iterations (e.g. days, months, years) allowing individuals to establish randomly, grow, mature, reproduce, aggregate into patches, and begin the process of colonization through facilitation, competition and secondary succession barring any subsequent, but more frequent and less severe, disturbances (e.g., fire or flood). Here, the dynamics may even be illuminated more or less continuously to understand how observed seral stages can develop. This type of model would have a high degree of realism.

Certain assumptions allow this effort to be avoided for models built to retrieve ecosystem recovery times (Section 3.3 outlines these assumptions and more in greater detail.). First, establishment of seedlings in space is random (Walker and del Moral, 2003). Second, for what little data exist on recovering ecosystems following ash-flow eruptions, distance from the eruptive source and thickness of deposits are not significant factors to the rate of recovery (Whilmshurst and McGlone, 1996). Third, local climate is correlated with recovery rates (Whilmshurst and McGlone, 1996). Fourth and finally, it is assumed here, any single patch that recovers $90 \%$ of its biomass carrying capacity is a proxy for full recovery of the entire initially disturbed surface; that is, given a patch is at $90 \%$ of its biomass carrying capacity, it is unlikely that an adjacent patch is at $0-5 \%$ of its biomass capacity. 
Landscape (a.k.a. spatially explicit) models, unlike metapopulation models, model organism movement and interactions continuously across space. They represent specific landscapes, specific organism movements and interactions, and species-specific properties (Munns et al., 2007). Such specificity promotes accuracy and realism over generality. The exception to this would be the general ecosystem model (GEM) by Fitz et al. (1996) intended "for use across a wide range of ecosystem types." Methods used in landscape models employ GIS software (e.g., Topping, 1999) or rule-based cellular automata (CA; e.g., Fuentes and Kuperrman, 1999). Because CA-based landscape models track organism movement and interactions across any adjacent cells in a matrix, CAbased landscape models can be considered a special case of metapopulation models. The argument used above for rejecting the use of metapopulation models for modeling datadeficient paleoecosystem recovery also applies to landscape models regarding heterogeneous landscapes. Furthermore, the GEM is not used because the hydraulic properties of the recovering groundwater systems are unknown for the LMPN.

\subsubsection{Model generality}

Odenbaugh (2005) defines the relative contrast between general and specific models as: "A model is more general than another model [if] the former successfully represents a larger number of systems than the latter." The model that follows does this in that it uses overall biomass per area rather than any specific attribute of individuals of a species. Much of the modeling developed for the above described methods have highly specific characteristics built for specific ecological problems in the modern world. Assessing risks to or managing ecosystems promotes the need for a high degree of 
specificity and realism in many research endeavors. Furthermore, these different methods are supported by richness in data paleoecological settings do not possess. More often than the applied cases, pure research has tended to approach primary succession from the perspective of understanding its generalities. However, the consensus is that "no general theory of succession has emerged that can predict the dynamics of species replacements in many different habitats (Walker and del Moral, 2003).” Few specific plant species are known in the LMPN fossil record. For the purposes of modeling vegetation dynamics in LMPN paleoecosystems, ecosystem biomass recovery is used instead of species succession.

\subsection{Model assumptions}

The following assumptions provide a conceptual framework for a recovering ecosystem from the initial state of sterilization to the carrying capacity of the system. The assumptions are:

1) Death and eradication of life on the landscape (i.e. sterilization) is complete following deposition of ash-flow tuffs. Large magnitude $\left(10^{3}-10^{4} \mathrm{~km}^{2}\right)$ tuffs of the LMPN are too hot and too thick for buried plants to emerge from burial (del Moral and Grishin, 1999) and plants are most likely incinerated.

2) Ash flow surface temperatures are not likely to interfere with ecological recovery for any extended period of time since surface cooling to below $100^{\circ} \mathrm{C}$ has been measured to be within 100 days (Kozu, 1934; Riehle, 1973).

3) Local climate is associated with recovery rates (Wilmshurst and McGlone, 1996; Walker and del Moral, 2003). Furthermore, albedo of the ash surface is likely 
important to local climate due to the altering of surface temperatures and their interaction with overlying air masses (Cross and Taggart, 1982; Jones et al., 2007).

4) Seedling establishment is random (Walker and del Moral, 2003). Additionally, area and distance from the margin are not significant to recovery rates.

Wilmshurst and McGlone (1996) observed from pollen analyses variable recovery times across the $20,000 \mathrm{~km}^{2}$ Taupo ash-flow that were unrelated to distances to the source of the eruption. Regarding estimated recovery times, the site nearest to the source (Ongarue) recovered the fastest. This is likely due to wind dispersal. For example, del Moral (1998) reports that on very isolated pumice at Mount St. Helens, $50 \%$ of the plants present are wind dispersers.

5) Temporal changes in biomass are closely associated with species change (Walker and del Moral, 2003).

6) The ecological landscape is recovered once $90 \%$ of the biomass carrying capacity has been reached (Coffin and Laurenroth, 1990). It is unlikely a patch has $0-5 \%$ of its biomass capacity if an adjacent patch is at $90 \%$ capacity. Moreover, similar root trace fossils, mean annual precipitation $\left(\mathrm{mm} \mathrm{yr}^{-1}\right)$ estimates, and textures in paleosols above and below the Rattlesnake Tuff (Retallack et al., 2002) provide evidence that LMPN paleoecosystems recover to their former states following large-scale eruptions. Modern studies on eruptions such as Taupo, New Zealand (Wilmshurst and McGlone, 1996), Mt. St. Helens, USA (Wood and del Moral, 1987), El Chichòn, Mexico (Burnham, 1994), and Montagne Pelèe, Martinique (Beard, 1976) make similar observations as well. 


\subsection{An ecosystem recovery model}

An ecosystem recovery model (ERM; Figure 7 \& Appendix D) was made to establish recovery times for plant primary productivity following large ash-flow eruptions in the LMPN. The following describes parameters and formulas of the ERM (see also Table 3).

Table 3. Model parameters, descriptions, and dimensions for the steps in the model that follow. In the last column for disturbance $d$ and seedling establishment rates $E$ values in parentheses are for the LMPN while values not in parentheses are for recovery on the Taupo Ignimbrite. nd indicates dimensionless values. See text for details regarding parameter values.

\begin{tabular}{|c|c|c|c|}
\hline Parameter & Description & Dimensions & Value \\
\hline$a$ & albedo & nd & $0-1$ \\
\hline MAP & mean annual precipitation & $m m \mathrm{yr}^{-1}$ & Varying \\
\hline$A E$ & actual evapotranspiration & $m m \mathrm{yr}^{-1}$ & Varying \\
\hline$N A A P$ & $\begin{array}{l}\text { net annual aboveground } \\
\text { primary productivity }\end{array}$ & $\mathrm{g} \mathrm{m}^{-2}$ & Varying \\
\hline FVC & fractional vegetation cover & nd & $0-1$ \\
\hline$d$ & disturbance rate & $\mathrm{yr}^{-1}$ & $\begin{array}{l}0.042(0.13)- \\
0.01(0.037)\end{array}$ \\
\hline$E$ & seedling establishment rate & $\mathrm{yr}^{-1}$ & $\begin{array}{l}0.05(0.05)- \\
0.3(0.3,0.2 \\
0.15,0.1)\end{array}$ \\
\hline
\end{tabular}

The model domain is a one dimensional ring of square meter plots. Variables in each plot are albedo $(a ; 0-1)$, mean annual precipitation $\left(M A P ; \mathrm{mm} \mathrm{yr}^{-1}\right)$, actual 
evapotranspiration $\left(A E ; \mathrm{mm} \mathrm{yr}^{-1}\right)$, net annual aboveground primary productivity $\left(N A A P ; \mathrm{g} \mathrm{m}^{-2}\right)$, and fractional vegetation cover $(F V C ; 0-1)$. One feedback is built into the model with $a$ directly dependent on $F V C$ after the first year. Initial albedo values, $a_{0}$ are randomly sampled from a uniform distribution with a range of 0.38 to 0.7 as measured from wet and dry ash of the Bishop Tuff in Jones et al. (2007; approximated from Figure 2).

From $a_{0}$, linear and nonlinear regressions estimate all variables except $F V C$, which is estimated from the ratio of plots with biomass to total number of plots (see formulas in Table 4). The significance of the fit of the linear equations assumes normality of the residuals and is estimated from $p$ values, while residual graph analyses are applied to estimate the goodness of fit of the nonlinear equations.

Table 4. Formulas used to estimate the different variables. Residual graph analyses were performed on the nonlinear relationships. All data are global in scale with the exception of the $M A P-a$ relationship formed only from North American data subsets of global data sets. See text for details.

\begin{tabular}{lll}
\hline Relationship & Formula & Data Source \\
\hline \hline MAP - $a$ & $M A P^{-1}=0.0136 \pm 0.0012(a)^{1.5436 \pm 0.1048}$ & $\begin{array}{l}\text { Huffman et al., 1997 (MAP); } \\
\text { Barkstrom et al., 1990 }(a)\end{array}$ \\
AE - MAP & $A E=0.6719 \pm 0.0171(M A P)^{*}$ & multiple; see Appendix E \\
NAAP $-A E$ & $N A A P=0.1854 \pm 0.2477(A E)^{1.3318 \pm 0.1968}$ & Rosenzweig, 1967 \\
$a-F V C$ & $\begin{array}{l}a=-0.8569 \pm 0.8272(F V C)^{2}+0.4744 \pm 0.9377(F V C) \\
+0.4605 \pm 0.2270\end{array}$ & multiple; see Appendix D \\
\hline
\end{tabular}

$* p<<0.05$

Recovery is repressed by disturbance and seedling establishment mortality. Two sets of frequencies are used. The pioneer stage of recovery representing the first 30 years 
in the model has different disturbance $d$ and seedling establishment $E$ rates than a post-pioneer stage (see Table 3). The greater values of $d$ are the pioneer stage disturbances and the smaller values are for time threreafter. Smaller values for $E$ are are the pioneer stage seedling establishments and the greater values are for time threreafter.

Disturbances in ecosystems in recovery on ash surfaces have high rates initially with respect to pre-eruption $d$ due to increased aridity caused by properties of the ash surface and lightening caused by friction of ash particles in the atmosphere (Cross and Taggart, 1982; Wilmshurst and McGlone, 1996; Walker and del Moral, 2003; Jones et al., 2007). $d$-number of disturbances per time period-is generally discussed in terms of return intervals until the next disturbance, or presented as a percentage of areal extent disturbed. For the first 30 years of the post-eruption Taupo surface $d$ is set at 0.042 (estimated from number of charcoal samples per recovery time in Wilmshurst and McGlone, 1996). For levels of a pre-eruption $d$ simulation studies give a guideline. They have applied a range of "low" to "high" $d$. For instance, Plotnick and Gardner (2002) use a range of $d$ from 0 to 0.4 in their landscape ecology model. Turner and Dale (1991) applied frequencies of $0.01,0.1$, and 0.5 to represent low, moderate, and high levels of disturbance in their landscape disturbance model. Botta and Foley (2002) applied $d$ equal to $0.005,0.01$, and 0.02 to a simulation study of Amazonian ecosystem dynamics. None of these reports validated their reasoning for using such ranges or values. Nevertheless, $d$ is tuned here within these ranges for recovery on the Taupo surface to meet recovery times estimated by Wilmshurst and McGlone (1996; see Table 3 above). The tuned $d$ is 0.01 (one disturbance in 100 years). For the LMPN, pioneer post-eruption $d$ are set at 0.13 from the highest mean fire disturbance return interval for the shrub steppe ecosystem 
near Paisley, Oregon reported in Miller and Rose (1999). The lowest fire disturbance return interval of 0.037 from Miller and Rose (1999) is used for post-pioneer stage $d$.

The value of a disturbance is thus a randomly sampled value up to the limit of the per plot carrying capacity $N A A P_{\max }$ at rate $d$. If a disturbance at year $j$ is greater than plot $i$, plot $i$ equals zero. Otherwise, biomass value disturbed is subtracted by the biomass in plot $i$.

Few studies make an explicit connection between field observations and seedling establishment rates appropriate for ecosystem models. Pioneer stage seedling establishment rates (denoted hereafter as $E$ ) for both Taupo and LMPN post-eruption surfaces are set at 0.05 from estimates of establishment of Epilobiuman gustifolium and Anaphalism argaritace on the Pumice Plains of Mount St. Helens by Wood and Morris (1990) in the early stages of its recovery. Since seed and seedling desiccation is the greatest cause of mortality in establishment (Fenner and Thompson, 2005) a low $E$ would likely persist for some time in the pioneer stage. Takenaka (2006) used values of $E$ ranging from 0.001 to 0.3 in a simulation study of seedling population dynamics. This range was applied in the ERM. Taupo pre-eruption $E$ were tuned to 0.3. LMPN preeruption $E$ were difficult to determine. They were likely to be less than that of Taupo with regard to increased seed desiccation, and thus, seed mortality, in the more arid climates of the LMPN. For completeness in the ERM, $E$ equal to $0.3,0.2,0.15$, and 0.1 were used. $E$ less than 0.1 tended to rarely recover fully.

Glenn-Lewin and van der Maarel (1992) define inhibition as "the prevention of plant maturation or growth, or, especially, the prevention of plant establishment, by existing plants." Spatial inhibition is produced from biomass differences with plot $i$ 
compared to plots $i-1$ and $i+1$. If both $i-1>i$ and $i+1>i, i$ dies. Temporal inhibition is produced from root biomass differences with plot $i$ compared to incoming seeds at time $j+1$ to $j+m$ which may establish themselves in plot $i$. In a root competition experiment, Gersani et al. (2001) concluded overlapping plant root systems compensate for sharing a common space with limiting below ground resources (water, nutrients, and soil/substrate porosity; Walker and del Moral, 2003) through 85\% increased root growth. Plants of the same species were potted simultaneously. Here, if a resident plot's root biomass is $85 \%$ greater than an incoming root system it has a $15 \%$ advance on the root growth increases both root systems will undertake. This allows the resident root system to dominate acquisition of limiting below ground resources. If resident root biomass is less than $85 \%$ of incoming root biomass the resident cannot dominate resource acquisition and is unable to compete with an incoming plant with greater resource acquisition efficiency; the resident will be, in effect, "crowded out" of its plot. This is a bias in the succession of smaller, short-lived plants toward larger, longer-lived plants. However, if the resident root biomass is neither less than $85 \%$ of the incoming root biomass nor greater than total incoming root biomass, both root systems become established in the plot. This action is meant to simulate the potential for the formation of thickets of the same species which may later inhibit other species (Walker and del Moral, 2003). Additionally, if the incoming root biomass is simply less than the resident root biomass, the resident lives on while the invasive never establishes itself in the plot. Forest root:shoot biomass ratios are multiplied by $N A A P$. As $N A A P$ increases in forests recovering on the Taupo Ignimbrite surface root:shoot ratios go from 0.456 at $N A A P<750 \mathrm{~g} \mathrm{~m}^{-2}$ to 0.226 at $750 \mathrm{~g} \mathrm{~m}^{-2}<$ 
$N A A P \leq 1500 \mathrm{~g} \mathrm{~m}^{-2}$ to 0.241 at $N A A P>1500 \mathrm{~g} \mathrm{~m}^{-2}$. Root:shoot biomass ratios for the LMPN are set at 1.837 for shrublands. Root:shoot ratio data from Mokany et al. (2006).

Each year begins with an estimate of $M A P$ from albedo followed by $A E$ from $M A P$ estimations, and then $N A A P$ from $A E$ estimations (Figure 8). Seedlings are established and disturbed. Established seeds that survive compete with any adjacent plots and any incoming plants. FVC of the plots is estimated and used to generate albedo values for the next year. The ecosystem is considered recover the first year $90 \%$ of the biomass carrying capacity is reached.

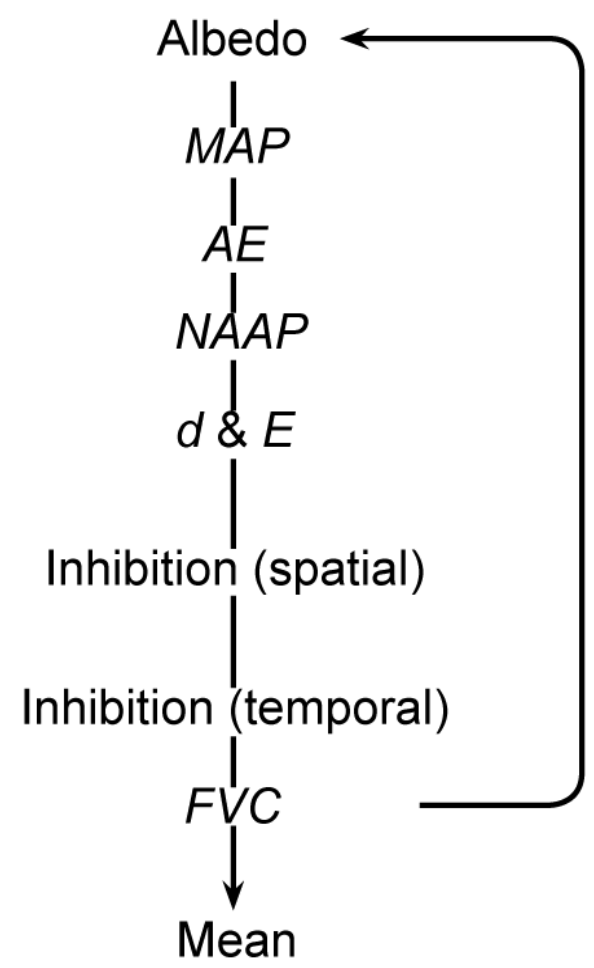

Figure 8. General diagram of model flow of steps described in Section 3.3.1. Steps within the loop are repeated across all plots and all years. 
Limited data are available with which to constrain the present model (Table 5).

The strength of work is in the empirical relationships and in the application of lessons from experiments and syntheses of data in the literature on competition and post-eruption aridity. Unfortunately, there is considerable uncertainty regarding general estimates of $E$ and $d$ despite the attention they receive in the literature (Walker, 1999; Walker and del Moral, 2003). Additionally, little is known about the effect of vast eruptions on groundwater.

Table 5. Degrees of uncertainty in the ERM. Considerations of different factors important to ecological recovery are not all present in the model. In general, empirical relationships and data from experiments are more applicable to paleoecosystem recovery in this effort than microsite surface properties or groundwater hydrology development due to data availability.

\begin{tabular}{|c|c|c|c|}
\hline Less & <-----------------------| & |------------------------’> & More \\
\hline$A E-M A P$ relationship & MAP - $a$ relationship & $E$ & Surface crusts \\
\hline \multirow[t]{3}{*}{$N A A P-A E$ relationship } & $a-F V C$ relationship & $d$ & Groundwater hydrology \\
\hline & Post-eruption aridity & root competition & \\
\hline & & light competition & \\
\hline
\end{tabular}

\subsection{Model validation}

To validate the ERM, the goal to generate model recovery times (MRT) similar to observed recovery times (ORT) following the Taupo eruption on the North Island of New Zealand in 1850 BP (Table 4). The methods used are an Anderson-Darling test for normality, single sample sign test of the medians, and the Brown-Forsythe test of equal 
variances. The steps involved are 1) to run 100 consecutive model runs; 2) test for normality using an Anderson-Darling test and the freeware software CumFreq (waterlog.info/cumfreq); 3) testing for a significant difference in the medians with a single sample sign test of the medians, and variances with Brown-Forsythe's test of equal variances.

Table 6. Observed recovery times for five sites on the North Island of New Zealand that followed the Taupo eruption in 1850 BP (Wilmhurst and McGlone, 1996). Mean annual precipitation ranges come from the National Institute of Water and Atmospheric Research (www.niwa.co.nz).

\begin{tabular}{lcc}
\hline Site & Recovery Time (yrs) & MAP $\left(\mathrm{mm} \mathrm{yr}^{-1}\right)$ \\
\hline \hline Ongarue & 120 & $2000-1500$ \\
Lake Rotonuiaha* & 145 & $2000-1500$ \\
Lake Tutira** & 175 & $1500-1250$ \\
Tunapahore & 200 & $1250-1000$ \\
Kohika & 225 & $1250-1000$ \\
\hline
\end{tabular}

* Wilmhurst and McGlone (1996) report a MAP of $2000 \mathrm{~mm} / \mathrm{yr}$

** Wilmhurst and McGlone (1996) report a MAP of $1400 \mathrm{~mm} / \mathrm{yr}$

It is unknown if the ORT's are at or near the mean or if they fall elsewhere in a potential normal or lognormal distribution since no standard deviation or error was given by Wilmshurst and McGlone (1996) regarding their estimates shown in Table 6 above.

Existing model output is a result of the inputs and the calibration to allometric relationships as well as the design of the model components and assumptions. 
3.7 Cumulative probability and waiting time models for allopatric speciation.

Orr (1995) focused on modeling speciation as a process of accumulating genic incompatibilities in allopatrically diverging populations. These incompatibilities, known as Bateson-Dobzhansky-Muller incompatibilities (BDMI's), are a conceptual model first described by Bateson (1909) and later discussed independently by Dobzhansky (1936) and Muller $(1939,1940)$. In this model (Figure 9) two separated populations with identical genotypes inherit different mutations to identical genes that later become fixed (i.e. genes with no other form (allele) in the population to substitute). When the populations encounter each other at a later time, after a physical barrier to migration no longer exists or is overcome, their hybrids are either inviable or sterile. It is also possible for just one population to undergo genetic change forming incompatible hybridizations with populations possessing ancestral genotypes (Muller, 1942). 


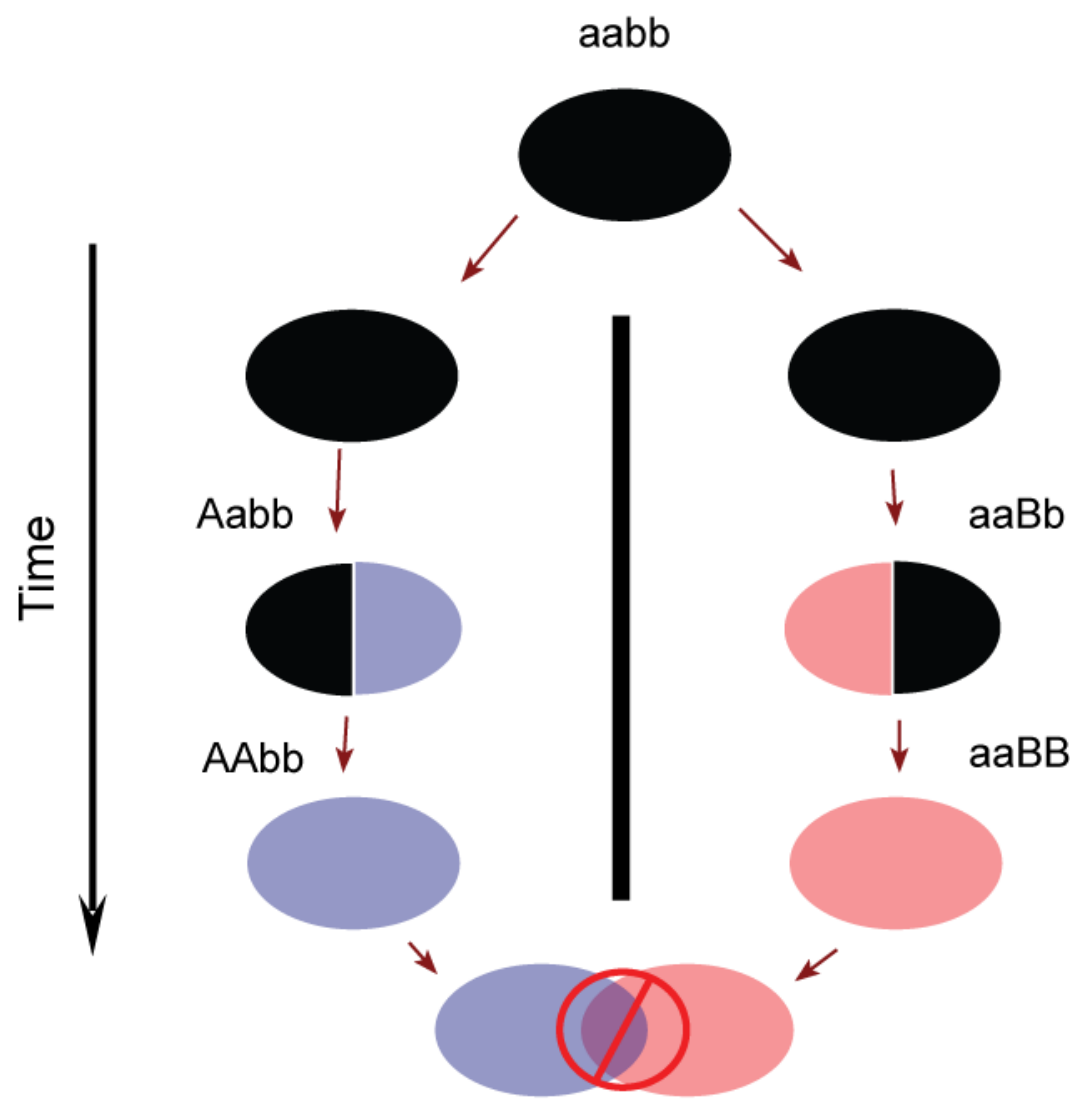

$\mathrm{AaBb}$

Figure 9. BDMI cartoon of a barrier-induced reproductive incompatibility. See text for details.

Orr (1995) modeled three scenarios: a single incompatibility, multiple incompatibilities, and complex incompatibilities among protein-coding genes. Orr (1995) suggests complex incompatibilities are more common than the first two for two main reasons: 1) complex incompatibilities substitute more nucleotides (i.e. three is more than two, four is more than three) per mutation, thus accruing more changes to the population; 2) single incompatibilities are often prevented by the generation of an unfit genotype (e.g. genotype $A A$ is compatible with $a a$, but neither are compatible with $A a$ where $A$ is the 
dominant allele and $a$ is recessive). The model for complex incompatibilities is as follows:

$$
S \approx 1-\exp \left(-\sum_{n=2}^{K} p_{n}\left(\begin{array}{l}
K \\
n
\end{array}\right)\right)
$$

Here $S$ is the cumulative probability of speciation, $K$ is the number of base pair substitutions, $n$ is the number of loci involved in an incompatibility, $p_{n}$ is the probability of each of the $n$ incompatibilities and $\left(\begin{array}{l}K \\ n\end{array}\right)$ is the binomial coefficient indicating the number of combinations of $K$ substitutions taken $n$ loci at a time and formulated as $\left(\begin{array}{l}K \\ n\end{array}\right)=$ $K ! /(n ![K-n] !)$

Values to the variables in Equation 1 were chosen using Orr's (1995) report as a guide. $K$ increases from 0 to $\infty$ and $n$ is set at 7 loci-the maximum number at which the fraction of possible paths from ancestor to successor stabilizes. Setting an upper limit with $n=7$ for complex incompatibilities should assist in generating the "fastest" possible speciation rate from Equation 1 because it is likely any speciation related to eruptions like the RST, PCT, and DvCT occurs along shared time intervals between ecosystems and evolution. Values for $p_{n}$ are more difficult to apply because there are few data on the probability of incompatibilities. Orr and Turelli (2001) estimated $p_{n}=10^{-6}$ or less. Their estimations were made from the fruit fly Drosophila and the fire-bellied toad Bombina. For these estimates, they did not model for complex incompatibilities, going only as far as multiple incompatibilities. Therefore, higher probabilities than what they suggest to be reasonable, however wild in their application, are explored to increase the rate at which speciation occurs in mammals. $p_{n}$ values ranging from $10^{-6}$ to as high as $10^{-4}$ are applied here following Orr (1995) and Gavrilets (2004). 
To obtain an estimated waiting time to allopatric speciation $t_{S}$ (years) a formula developed by Orr and Turelli (2001) and discussed in Gavrilets (2004) is used. The formula is

$$
t_{S}=\frac{Q}{2 w}
$$

$Q$ is the number of substitutions required for reproductive isolation and $w$ is the substitution rate. The coefficient of 2 represents a parent and daughter population pairing. $Q$ is estimated from Equation 1 when $\mathrm{S} \approx 1$. Relating speciation to eutherian mammals, substitution rates are estimated for house mice (Mus musculus; $2.2 \times 10^{-9}$ substitutions/site/year; Waterson et al., 2002) and humans (Homo sapiens; $4.5 \times 10^{-9}$ substitutions/site/year; Waterson et al., 2002) by multiplying the per site substitution rates by the number of protein-coding genes (house mice and humans have been estimated at 20,210 and 19,042 protein-coding genes, respectively; Church et al., 2009). The bimodal pattern of the number of taxa with increasing mass (Figure 4A-C) has two modes in the region of $50-150 \mathrm{~g}$ and $60-160 \mathrm{~kg}$. House mouse and human masses each lie near or in the two respective modes as illustrated in Figure 4C and described in Section 2.1.3. Since their masses are in the modes of greatest diversity this suggests speciation may be highest at these two modes.

Additionally, to explore the difference in evolutionary rates as observed by Millien (2006) of mammalian fossil island taxa compared to their mainland counter parts, $t_{S}$ is divided by 3.1. This step is intended to simulate a more rapid (punctuated) change in a LMPN eutherian mammal population.

One advantage of Orr's (1995) and Orr and Turelli’s (2001) models (Equations 1 and 2) is that unlike others (c.f., Gavrilets, 1999; Lynch and Force, 2000; Kondrashov, 
2003) they require no population estimates. Population variables generally accompany the genetic variables in these modeling efforts. Though density estimates are possible for members of paleobiological communities using allometric equations, these models are simple and general enough to provide a rough estimate, and that is all that is required for this study. The importance of these speciation models is to have a quantitative representation of the process of speciation for comparison to the process-based ERM described above. The intention is meant to support further qualitative and semiquantitative estimates of the time for speciation obtained from studies of the patterns of speciation. Two disadvantages of Equations 1 and 2 are that they strictly represent the genetic inheritance system and biological species concept. 
Chapter 4

Results

\subsection{Validation}

ERM median and variance output run for the Taupo scenario comparing model recovery times (MRT) and observed recovery times (ORT) indicate there is no statistical difference (Table 7). Additionally, 100 runs of MRT output are not normally distributed. Log-normal distributions are found in many reports other recovery times (Lawrence, 1988). Though the processes for time to recovery from illness in Homo sapiens and ecosystem recovery on barren landscapes are different, they illustrate similar event-time data types. Furthermore, the ERM is designed similarly to Kapteyn's Analogue Machine for positively skewed distributions (Aitchison and Brown, 1957). In this machine, nine rows of $\triangle$-shaped wedges divide sand in two directions, left or right. In the ERM (Figure 7), the state-based steps are analogous to the wedges.

Table 7. Validation results for the model recovery times (MRT's) and observed recovery times (ORT's) following the Taupo eruption. The MRT data are not normally distributed, while the median and variance cannot be determined to be significantly different from the median and variance of the ORT data.

\begin{tabular}{|c|c|c|c|c|c|}
\hline Parameter & $\begin{array}{l}\text { MRT } \\
\text { (yrs) }\end{array}$ & $\begin{array}{l}\text { ORT } \\
\text { (yrs) }\end{array}$ & $\begin{array}{l}\text { Single Sample } \\
\text { Sign test }\end{array}$ & $\begin{array}{c}\text { Brown-Forsythe } \\
\text { test }\end{array}$ & $\begin{array}{c}\text { Anderson-Darling } \\
\text { test }\end{array}$ \\
\hline Median & 183.5 & 175 & $\begin{array}{c}\text { Test statistic }=0.99 \\
t_{\text {crit }, \alpha=0.05}=-1.64\end{array}$ & & \\
\hline $\begin{array}{l}\text { Standard } \\
\text { Deviation }\end{array}$ & 72.67 & 41.92 & & $\begin{array}{c}W=0.491 \\
F_{\text {crit }, \alpha=0.05,1,103}=3.9\end{array}$ & \\
\hline$n$ & 100 & 5 & & & $\begin{array}{l}A^{*^{2}}=15.18 \\
A^{2}{ }_{\text {crit }, \alpha=0.05}=0.751\end{array}$ \\
\hline
\end{tabular}




\subsection{Model stability}

Stability of the model is assesed using standard deviations (Figure 10). The standard deviation decreases as time increases unless further disturbance occurs removing or reducing NAAP in the plots. Thus, the model appears to be stable suggesting errors accumulating in the model calculations are not increasing.

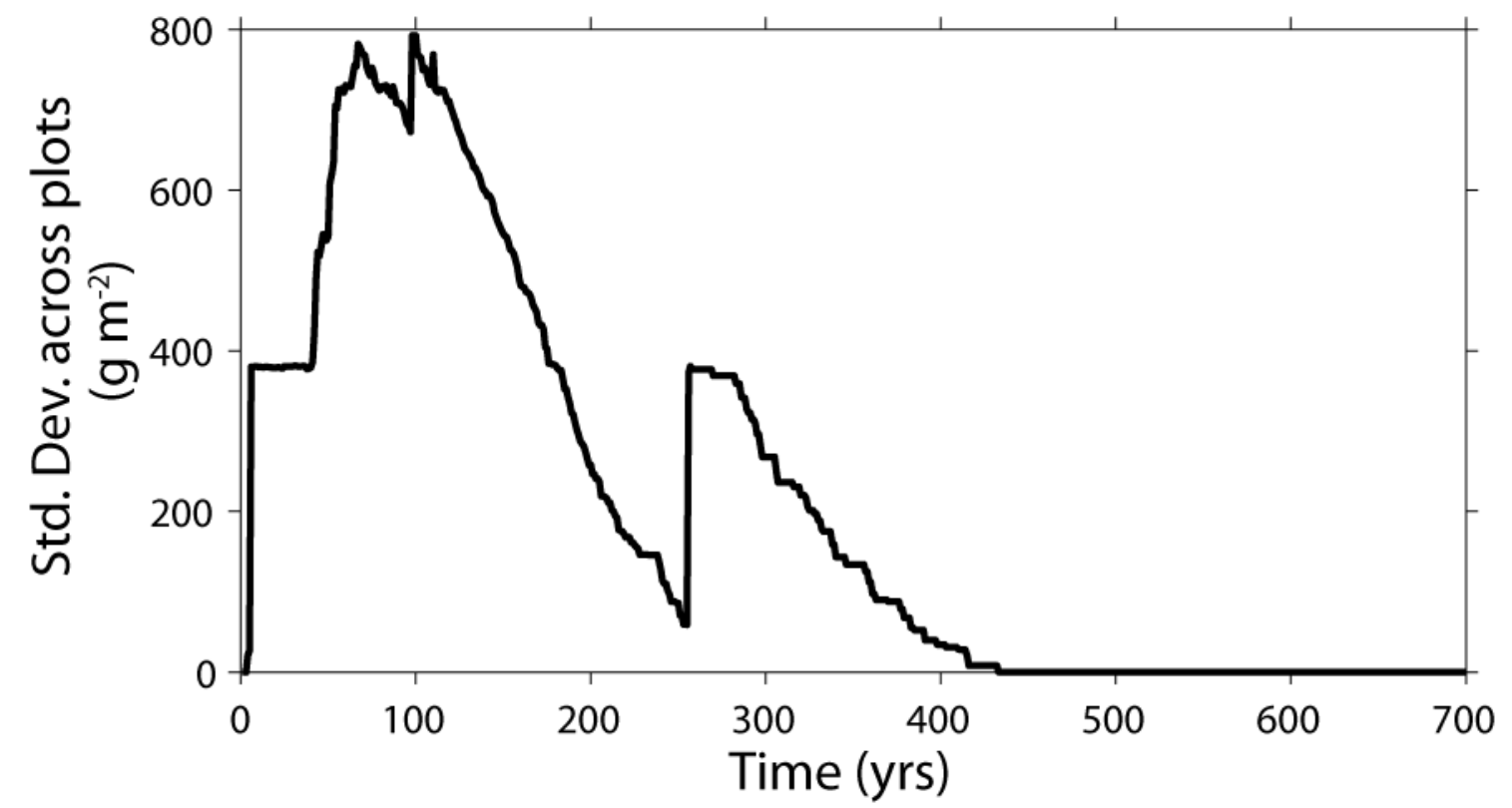

Figure 10. Standard deviation of biomass across plots over time for one model run. $N A A P_{\max }=2719 \mathrm{~g} \mathrm{~m}^{-2}$, $d=0.042-0.01$, and $E=0.05-0.3$.

\subsection{LMPN recovery times}

Recovery times for $N A A P$ in the LMPN ranged from 62 and 206 years for $E=$ $0.3,77$ to 394 years for $E=0.2,88$ to 665 years for $E=0.15$, and 133 to 1902 years for $E$ $=0.1$. Table 8 provides these ranges, $E$, mean and standard deviations. For comparison, Parkinsonia microphylla, a tree in the North American desert southwest, was calculated 
by Shreve (1917) as $1.6 \%$ seedling survival from germination. MAP at this study site near Tucson, Arizona is approximately $300 \mathrm{~mm} \mathrm{yr}^{-1}$. MAP ranges for the LMPN are estimated at $846-117 \mathrm{~mm} \mathrm{yr}^{-1}$ (Retallack, 2007).

Table 8. Results of the ERM with respect to the four E. Corresponding MRT ranges, medians, means, and standard deviations at 100 runs each are shown increasing as $E$ decreases. All other parameters remain the same.

\begin{tabular}{ccccc}
\hline$E\left(y r^{-1}\right)$ & Range $(y r)$ & Median (yr) & Mean (yr) & Std. Dev. (yr) \\
\hline \hline 0.30 & $62-206$ & 87 & 98.33 & 32.74 \\
0.20 & $77-394$ & 136 & 148.71 & 62.39 \\
0.15 & $88-665$ & 224 & 260.60 & 145.49 \\
0.10 & $133-1902$ & 492 & 600.22 & 391.85 \\
\hline
\end{tabular}

\subsection{Speciation model output}

The cumulative probability of speciation $S$ increases with increasing number of substitutions $K$ (Figure 11). Additionally, $S$ increases with increasing proability of incompatibility $p_{n}$. Waiting time to speciation $t_{S}$ calculated for the number of incompatibilities for reproductive isolation $Q=18,20$ and $Q=29,31$ with $p_{n}=10^{-4}$ and $p_{n}=10^{-6}$, respectively. A range of $Q$ 's is used for purposes of providing flexibility of the estimates slightly less than and greater than when $\mathrm{S}$ first equals 1 . Each $t_{S}$ estimated at each $p_{n}$ is also calculated for substitution rates $w=4.19 \times 10^{-5}$ and $9.09 \times 10^{-5}$ (Table 9; human and house mouse substitution rates, respectively). Additionally, estimates for a 3.1 increase in evolutionary rates of island taxa from Millien (2006) are presented also. At $p_{n}$ $=10^{-4}$ minimum times for speciation $\min \left(t_{S}\right)$ appear to range approximately from 100,000 - 230,000 years from Equation 2 (Section 3.7) while taking a 3.1 increase in evolutionary rates for isolated taxa gives and approximate $\min \left(t_{S}\right)$ range of 33,000 - 75,000 years. 


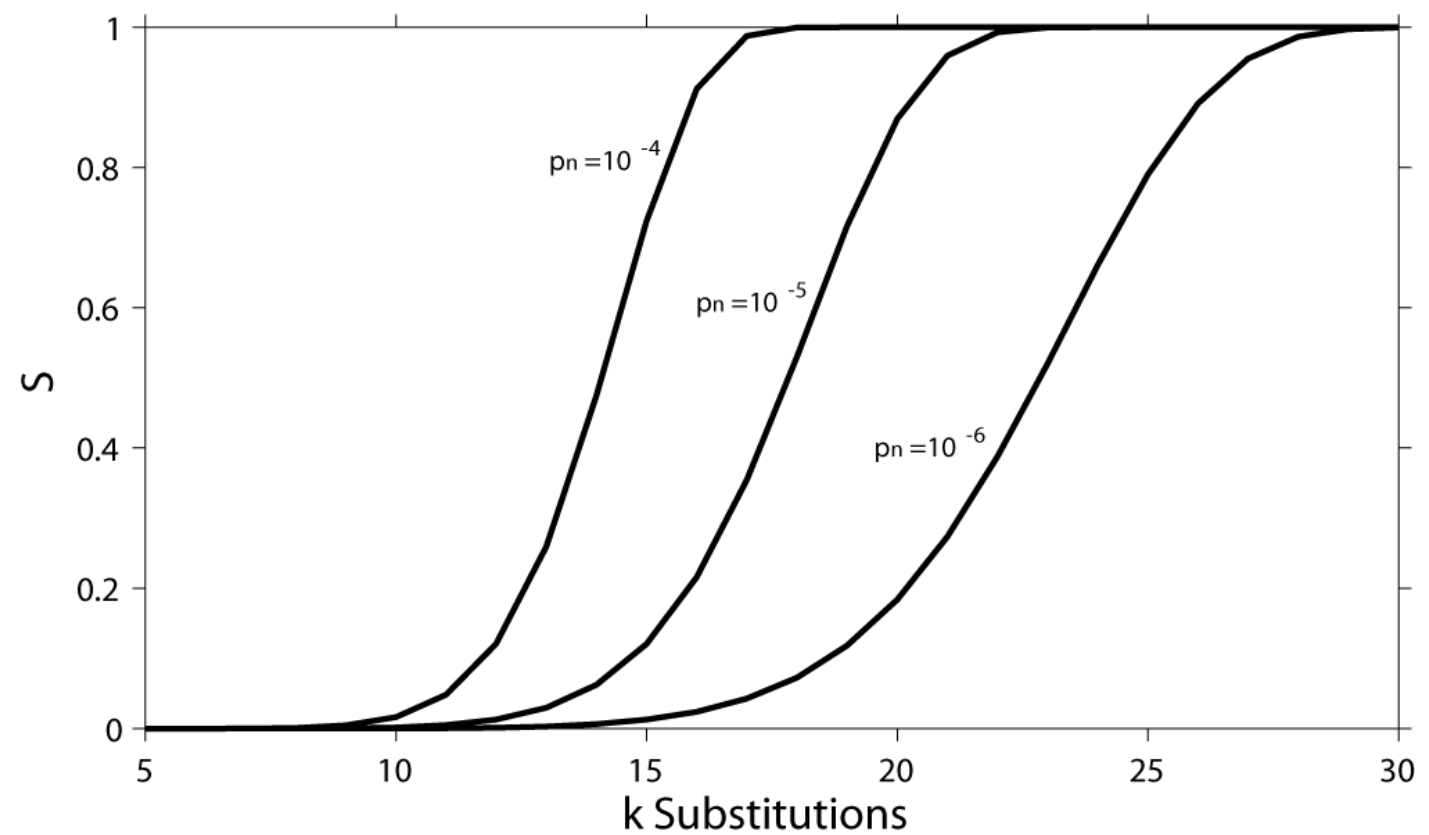

Figure 11. Cumulative probability of speciation $S$ with respect to $K$ substitutions. $S$ is plotted with $p_{n}=10^{-4}$, $10^{-5}$, and $10^{-6}$ increasing more slowly with respect to $K$ at smaller $p_{n}$.

Table 9. Estimates of $t_{S}$ at $p_{n}=10^{-4}$ and $10^{-6}$ and $w=4.19 \times 10^{-5}$ and $9.09 \times 10^{-5}$ for $Q=18,20$ and $Q=29$, 31 , respectively. Estimates for $t_{S}$ with a 3.1 increase in evolutionary rates as reported for fossil island taxa in Millien are also provided.

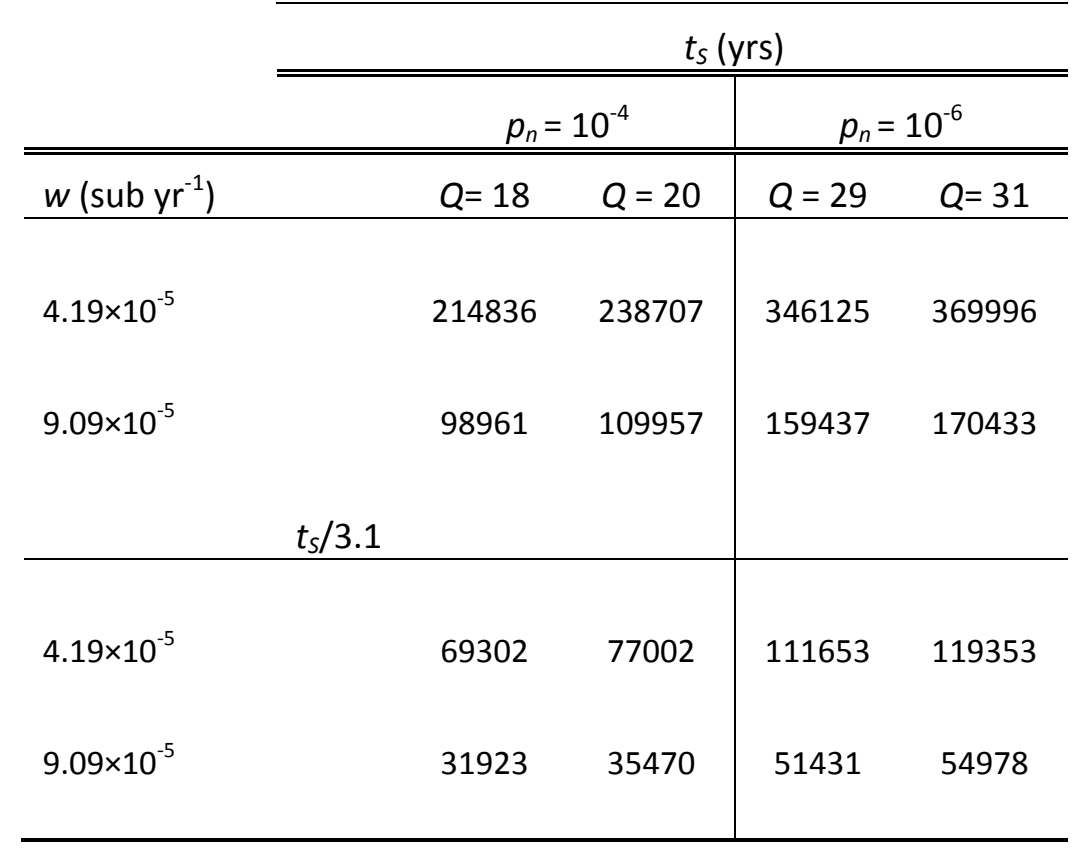




\subsection{Testing the hypotheses}

Comparing speciation $\left(t_{S}\right)$ and recovery times $\left(t_{R}\right)$ generated by the model it is evident the null hypothesis is to be rejected without a need for statistical testing. Recovery times are short relative to speciation times (Table 10). Therefore, it is unlikely isolated mammal species form new species following large-scale ash-flow deposition in the LMPN (Table 11 and Figure 12).

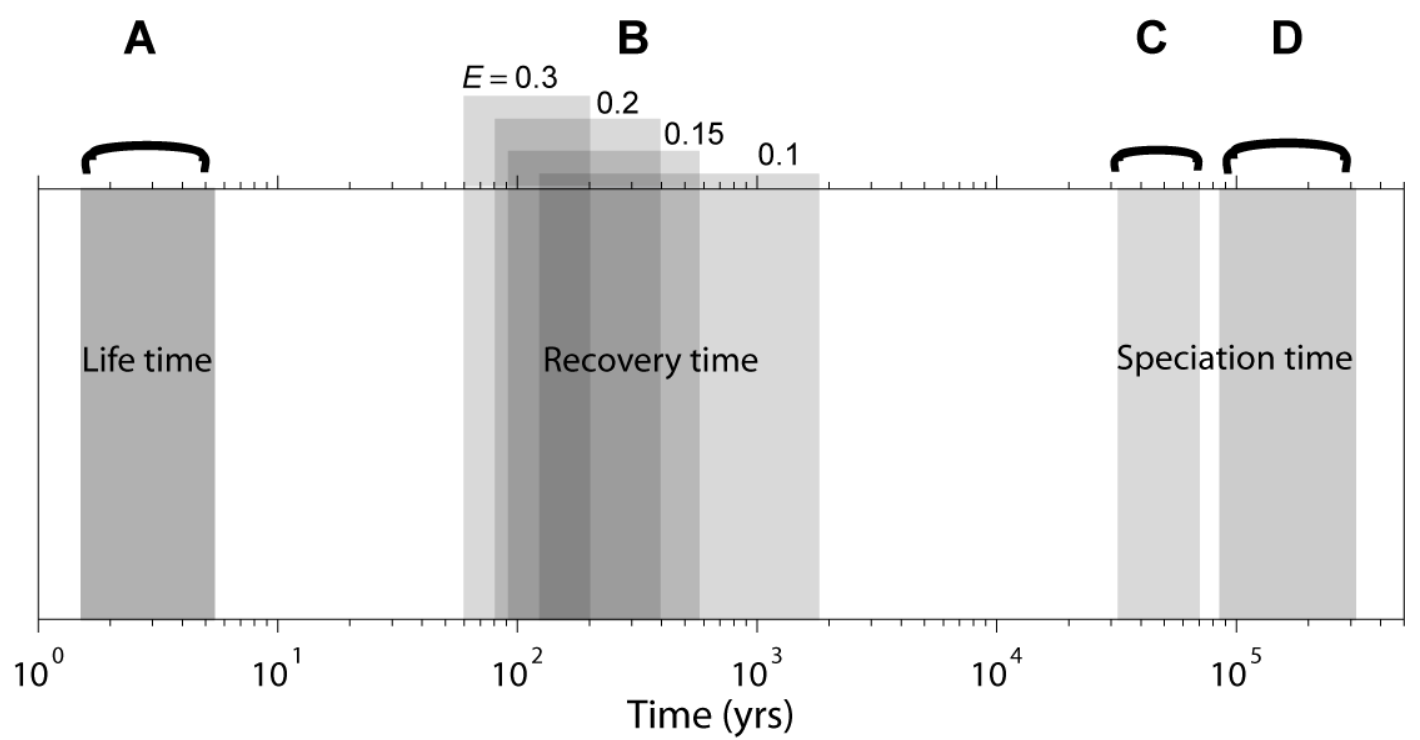

Figure 12. Comparison of A) a range of mammalian life expectancies spanning the LMPN body mass dual optima to B) the $E$-based LMPN $N A A P$ recovery times to C) $\min \left(t_{S}\right)$ of mammals belonging to the body mass dual optima with Millien's (2006) 3.1 increase in evolutionary rates to D) $\min \left(t_{S}\right)$ of mammals belonging to the body mass dual optima without a 3.1 increase in evolutionary rates. Mammalian life expectencies calculated from data in Damuth (1982) with the formula Life expectancy (yrs) = $0.0963 \pm 0.0753$ (Body mass $(\mathrm{g}))^{0.3345 \pm 0.0588}$. Different values of $E$ are designated for each associated recovery time range. For $\min \left(t_{S}\right), p_{n}=10^{-4}$ and $Q=18$. 
Table 10. Relationships between maximum MRT $\max \left(t_{R}\right)$ for $N A A P$ and the minimum time for speciation in small and large mammals $\min \left(t_{S}\right)$ under model conditions as described in Section 3.7. Two $\min \left(t_{S}\right)$ values are shown for small and large mammals. The value in without parentheses are $\min \left(t_{S}\right)$ with respect to a 3.1 increase in evolutionary rates. $\min \left(t_{S}\right)$ values in parentheses are values with this factor removed.

\begin{tabular}{lccc}
\hline & & \multicolumn{2}{l}{$\min \left(t_{S}\right)(\mathrm{yrs})$} \\
\cline { 2 - 4 } & $\max \left(t_{R}\right)(\mathrm{yrs})$ & Small Mammals & Large Mammals \\
\hline \hline & 1902 & $31,923(98,969)$ & $69,302(214,836)$ \\
$\max \left(\mathrm{t}_{\mathrm{R}}\right)(\mathrm{yrs})$ & $=$ & $<$ & $<$ \\
Small Mammals & $>$ & $=$ & $<$ \\
Large Mammals & $>$ & $>$ & $=$ \\
\hline
\end{tabular}

Table 11. Results of the null $\left(H_{0}\right)$ and alternate $\left(H_{1}\right)$ hypothesis tests as described in Section 2.3.2. $H_{0}$ is rejected and $H_{1}$ is accepted. Therefore, speciation in mammals takes too long a period of time for largescale pyroclastic flows to assist in generating new species.

\begin{tabular}{lccc}
\hline & & $\min \left(t_{S}\right)(\mathrm{yrs})$ & \\
\cline { 3 - 4 } Test & & Small Mammals & Large Mammals \\
\hline \hline$H_{0}$ & $\max \left(t_{R}\right)(\mathrm{yrs})$ & reject & reject \\
& & & \\
$H_{1}$ & $\max \left(t_{R}\right)(\mathrm{yrs})$ & accept & accept \\
\hline
\end{tabular}




\section{Chapter 5}

Discussion

"As my contribution to the fight against the information explosion I have completely excluded those topics about which I have nothing to say regardless of their importance."

-Richard Levins, 1968

\subsection{Recovery}

Terrestrial ecological recovery following the deposition of ash-flows can be considered as a transition from a purely abiotic domain to a biotic domain. Whether one considers succession the development of a superorganism (Clements, 1916) or the result of happenstance (Gleason, 1926), recovery on ash-flows is a change from bare ground to a surface (and subsurface) populated with bacteria, protists, plants, fungi, invertebrates, and vertebrates. Moreover, due to the variety of modes and directions in which succession and its respective studies proceeds, a general theory is presently not feasible (Walker and del Moral, 2003). Despite this absence of generality, Schneider and Kay (1992) propose that ecosystems succeed from sere to sere by effectively reducing the equilibrium energy gradient imposed by incoming solar radiation with increased energy capture, energy flow activity, and number of energy and material cycles. The authors observe this in radiative measurements from a thermal infrared multispectral scanner of different ecosystem types in the H.J. Andrews Experimental Forest, halfway between Sisters and Sweet Home, Oregon in the Cascade Range. Measurements taken from a quarry, clear-cut, Douglas fir plantation, natural forest, and 400 year old Douglas fir forest indicate a reduction of the surface temperature and an increase in the net radiation 
flux absorbed at the surface. This approach, at the very least, may serve as a baseline for a theory of succession among all living kingdoms.

\subsection{Timing}

A relevant question to this report is: what is the appropriate determination for the timing of recovery? As mentioned in Assumption 8 of Section 3.2., this report indicates recovery occurs when $90 \%$ of the biomass per plot has accumulated. In modern settings the timing of recovery within a range of climates is generally over hundreds of years. However, the measure of recovery estimated across assorted studies can itself be different furnishing varied recovery times. Additionally, matters of scale (temporal or spatial) regarding experiments and experimental environment (i.e. field, lab, greenhouse, or software) may decide what feature of the recovery process will be measured. Table 14 organizes the general locations, disturbance types, environments, recovery times, and measures used to indicate recovery or present stage. Mostly, recovery times given by these accounts are relatively congruent with one another. They may also fit criteria for generating correlations with climate variables like temperature and precipitation, but more data are needed and the data present are likely not enough to form a sensible relationship.

Regarding congruence of recovery times, early stages of succession appear to qualitatively align. For instance, Chapin et al. (1994) describe a succession of seres following deglaciation at Glacier Bay, Alaska as "Pioneer" in the first 20 years, dominated by dryas after 30 years, dominated by alder after 50 years, and later dominated by spruce after 100 years. Meanwhile, in northcentral Colorado at the Central Plains 
Experimental Range (CPER), a shortgrass community was dominated by Bouteloua gracilis after 50 years on abandoned agricultural fields (Coffin and Laurenroth, 1990). At Glacier Bay, the glacial till unveiled by the melting glacier sets the ecological landscape back to zero in a biome dominated by spruce trees, whereas in the CPER the landscape is dominated by grasses which are faster growing, shorter lived plants. 
Table 12. Different regional studies of succession and their disturbances, environments, recovery times, and measures of recovery.

\begin{tabular}{|c|c|c|c|c|c|}
\hline Location & Disturbance & Environment & Recovery Time (yrs) & Measure & Source \\
\hline $\begin{array}{l}\text { Montagne Pelée, } \\
\text { Martinique }\end{array}$ & nuée ardentes & $\begin{array}{l}\text { Tropical } \\
\text { Forest }\end{array}$ & 60 & $\begin{array}{l}\text { Return of vascular } \\
\text { plants }\end{array}$ & Beard, 1976 \\
\hline $\begin{array}{l}\text { Rakata Is., Sunda Straits, } \\
\text { Indonesia }\end{array}$ & $\begin{array}{l}\text { Krakatau eruption } \\
\text { and caldera collapse }\end{array}$ & $\begin{array}{l}\text { Tropical } \\
\text { Forest }\end{array}$ & $>100$ & Number of species & Whittaker et al., 1989 \\
\hline Northcentral Colorado & Fire, grazing & $\begin{array}{l}\text { Semiarid } \\
\text { Grassland }\end{array}$ & $20-65$ & $\begin{array}{l}90 \% \text { biomass from } \\
\text { computational model } \\
\text { with validation }\end{array}$ & $\begin{array}{l}\text { Coffin and Laurenroth, } \\
1990\end{array}$ \\
\hline Glacier bay, Alaska & Glacier & Glacial Till & $100-200$ & Spruce arrival & Chapin, III et al., 1994 \\
\hline $\begin{array}{l}\text { North Island, New } \\
\text { Zealand }\end{array}$ & Taupo ash-flow & $\begin{array}{l}\text { Temperate } \\
\text { Forest }\end{array}$ & $120-225$ & $\begin{array}{l}\text { Trace Pteridium spore } \\
\text { and charcoal } \\
\text { levels } / C^{14} \text { dating }\end{array}$ & $\begin{array}{l}\text { Wilmshurst and } \\
\text { McGlone, } 1996\end{array}$ \\
\hline Grand Canyon, Arizona & Debris flows & $\begin{array}{l}\text { Desert Alluvial } \\
\text { Fans }\end{array}$ & $240-285$ & $\begin{array}{l}\% \text { cover of long-lived } \\
\text { plants } / C^{14} \text { dating }\end{array}$ & Bowers et al., 1997 \\
\hline Sonoran Desert, Arizona & Man-made & Desert & $>78$ & $\begin{array}{l}\text { No. of species, no. of } \\
\text { plants, \% cover }\end{array}$ & Guo, 2004 \\
\hline $\begin{array}{l}\text { Central and southest } \\
\text { Montana }\end{array}$ & Fire & Shrub Steppe & 625 & \% sagebrush canopy & Cooper et al., 2007 \\
\hline
\end{tabular}


Recovery on Mount St. Helens has been studied since its face-changing eruption on May 18, 1980. However, it is still relatively unknown when it will be fully recovered. Crisafulli et al. (2005b) indicate in their Figure 20.3 the forest system response may return to its pre-eruptive productivity levels in 100 years. By 2005, the lupine pioneer species on the Pumice Plain immediately north of St. Helens had given way to competitors (Agrostis, Hypochaeris, and Polytrichum; del Moral and Lacher, 2005). This is consistent with Glacier Bay's "Pioneer" stage timeline of 20 years. If this rate of recovery continues at Mount St. Helens, perhaps the ecosystem will have made a full recovery in 100 years.

In ancient settings, climate change-induced succession has been well documented (Graham and Grimm, 1990; Overpeck et al., 1992). However, less is known regarding post-disturbance succession in the framework of paleoecology, especially from volcanic activity. Furthermore, from the succession patterns that are inferred from the rock record, fine-scale detail of their timing is difficult to observe.

Taggart and Cross (1974, 1990; and Cross and Taggart, 1982) suggest patterns of change from pollen and plant macrofossil assemblages from the Sucker Creek Formation (15.46-14.77 Ma; Downing and Swisher, 1993) indicate succession instigated by volcanic activity, fire, and climate. Succession is inferred from the assemblages themselves and numerous volcanic deposits in the stratigraphic sections they sampled and measured. Cross and Taggart (1982) estimate, provided no diastems break the sequences, these sections were generally deposited within 10,000 years.

Bubnoff units $B\left(1 \times 10^{-6} \mathrm{~m} / \mathrm{yr}\right)$ were used by Cross and Taggart (1982) to estimate deposition times for fluvial $(86,000 B)$ and lacustrine $(5,800 B)$ systems. Some 
sandstones units were 6-9 m thick giving approximate deposition time estimates of 70105 years while $3 \mathrm{~m}$ of lignitic shale is estimated to be deposited in roughly 525 years. Nonetheless, no recovery times were given for suspected successions of any of the described associations from any of the deposits. In spite of all these estimates, at least regarding plant macrofossils, Burnham et al. (1992) suggest they are typically deposited in a single year immediately around the locality of deposition.

\subsection{Speciation}

Examples specifically relating mammalian evolutionary responses to volcanic eruptions are few (e.g. Louys, 2007; Louys et al., 2007). More data and hypotheses exist on mammalian ecological responses instead (Taggart and Cross, 1990; Crisafulli et al., 2005a; Hanser and Huntley, 2006).

Better demonstrations of evolutionary responses are found in terrestrial invertebrate studies concerning the result of the effects of volcanic eruptions on allopatric speciation (Carson and Templeton, 1984; Morgan-Richards et al., 2000; Vandergast et al., 2004). The closest example to the mammalian dichopatric speciation-ash-flow eruption scenario is from changes in weta beetles following the Taupo eruption. MorganRichards et al. (2000) suggest the weta Hemideina thoracica on the North Island of New Zealand dispersed across the Taupo ash-flow surface at a minimum of $100 \mathrm{~m} /$ generation (one generation is $\sim 2$ years). Furthermore, differences between populations sampled along the eastern shore of Lake Taupo indicate hybridization of four clines over a distance of $38 \mathrm{~km}$; the result being secondary contact of allopatrically divergent 
populations that differentiated following the eruption. It is presumed the clines of $H$. thoracica will become homogenized over time.

To understand timing of speciation in mammals, one of the shortest intervals from the fossil record is 1000 years. From 5000-4000 ka, MacDonald (1981) suggests anagenesis likely occurred from Bison antiquus antiquus to B. bison bison. However, MacDonald (1981) also suggests B. antiquus occidentalis could be an intermediate from 10,000-4000 ka. Despite this short interval, speciation is not in response to ash-flow eruptions. However, the potential 1000 year B. bison speciation interval is less than the maximum recovery time of 1902 years computed with $E=0.1$.

In addition to few data on mammalian evolutionary responses to volcanic eruptions, there may not even be an indirect affect of eruptions on mammalian speciation. Cathers et al. (2010) have recently reported a correlation between Cenozoic climate changes with ash-flow eruption volumes in western North America. However, studies and reviews of the relationship between climate and mammalian extinction and speciation indicate this matter to be unresolved (Prothero, 1999, 2004; Alroy et al., 2000; van Dam et al., 2006; Louys, 2007). It may well be that mammal populations form new species more readily from active processes such as competition and foraging-driven or density-dependent dispersal than the passive processes of happenstance or directional environmental change. Additionally, Taggart and Cross (1990) demonstrate a specific case of a grazing fauna collected within sediments that contain pollen assemblages representing post-eruption successional grass-forb associations. If grasses could be established and widespread in a short time after the eruption of these large-scale ashflows, perhaps isolated populations of grazing mammals and their associated taxa would 
reunite well in advance of speciation. Moreover, vegetated "oases" of plant associations other than grasses and forbs may not be accessible to all members of nearby communities due to a lack of adequate resources at, or en route to, such sites. Passage may be eased by grasses better than ash surfaces alone. Since small mammals have demonstrated their capacity to locate, find adequate forage in, and inhabit oases on the pyroclastic flow of Mount St. Helens (Crisafulli et al., 2005a) - a greatly reduced example in magnitudewidespread grasses may possibly unite isolated populations of non-grazers in a short time as well by island hopping along oases.

\subsection{ERM dynamics}

Decreasing $M A P$ decreases maximum $N A A P$ and $F V C$ (i.e. biomass carrying capacity and maximum vegetation cover, respectively). However, leaving $d$ and $E$ unchanged generates shorter recovery times. This is unrealistic because $F V C$ gives a measure of the success and extent seedlings have in different climates. Therefore, in the case of recovery times in different climates tuning $E$ was required to determine an adequate calibration of the model before examining the LMPN recovery times. Tuning $d$ was not required since there was some data available to use in the simulations.

Concerning variability between the model runs, there is considerable contingency based on the stochastic nature of $d$ and $E$. A decrease in $E$ causes $d$ to have a greater influence over the trajectory in the timing of ecosystem and per plot biomass recovery. The same can be said if $d$ were decreased instead. Such a role for stochasticity and contingency in the ERM is analogous to Gould's (1989) description of contingency in the history of life on Earth. Rewinding the tape recorder of life and recording over the last 
recording will record a different evolutionary outcome. Though some MRT output are the same, how the plots developed are not.

\subsection{Coda for ERM limitations}

Limitations of the ERM remain data deficiencies with their associated uncertainty. In addition to this primary issue is the choice of model. With more data the ERM is likely to change from allometric and regression equations and simple rule based algorithms to more accurate rules or numerical solutions in models described in Section 3.2.1. At this time further data mining, experiment, and validation is needed to increase the realism of the model.

\subsection{Future work}

Future work should establish better estimates of $E$ and $d$. This could be done in the literature in conjunction with direct contact with ecologists studying succession and their associated ecosystem dynamics. Additionally, experiments which determine the affects of root inhibition in ash for pioneer plant species and species interactions in later stages would improve understanding of competition processes. Pollen rich outcrops or sediment cores with any of the three LMPN large ash-flow tuffs at their base are ideal such as those sampled and measured by Wilmshurst and McGlone (1996). Such a discovery would provide interpretation of actual events. This would aid in guiding the modeling of the processes in the LMPN to match preserved patterns. Finally, analyses of the ERM itself will generate a better knowledge on its quality. Sensitivity analyses of the 
parameters and variables, stability analyses for understanding model output error, and uncertainty analyses of parameter error are all potential directions to explore. 


\section{Chapter 6}

Conclusions

The purpose of this thesis is to explore the potential for speciation in mammals following the eruption of large-scale ash-flow tuffs in the LMPN. To accomplish this initial exploration of the dynamics in ecosystem recovery were studied and implented in the ERM. The intent was to form an approximate answer to the question of mammalian evolutionary responses to extensive volcanic phenomena.

Unlike other models equipped to study ecological recovery, the ERM here uses general relationships between the biotic and abiotic domains to establish recovery times rather than apply site and/or species-specific characteristics of either domain. In effect, all one needs is a precipitation range, along with estimates of disturbace and seedling establishment rates and the model is essentially set to proceed. More importantly, this quality makes it applicable to terrestrial paleoecological studies with similar coarseness in data. The strength of the model comes from its heavy reliance on empirical relationships or other observations found in the literature. By this account, it should broadly reflect much of the present state of knowledge on ecological recovery and interactions between organisms with each other and their environment. As indicated through validation in Section 4.1 (Table 5), the ERM generates a distribution statistically indiscernible from the distribution of ORT data following the Taupo eruption (Wilmshurst and McGlone, 1996).

Despite all efforts made in generating the ERM, results of its recovery time output — as compared to Orr's (1995) and Orr and Turreli's (2001) models of speciation and the literature - prove to be too short for populations of mammals to speciate upon 
becoming isolated. Under these circumstances, following such extreme events as largescale ash-flow eruptions in the LMPN, potential for speciation in mammals is unlikely. 
References

Alroy, J., 1998a, Cope's rule and the dynamics of body mass evolution in North American fossil mammals: Science, v. 280, no. 5364, p. 731-734.

Alroy, J., 1998b, Diachrony of mammalian appearance events: implications for biochronology: Geology, v. 26, no. 1, p. 23-26.

Alroy, J., 1999, Putting North America's end-Pleistocene megafaunal extinction in context: large-scale analyses of spatial patterns, extinction rates, and size distributions, in MacPhee, R. D. E., ed., Extinctions in near time: causes, contexts, and consequences: New York, Plenum Ress, p. 105-143.

Alroy, J., 2000, New methods for quantifying macroevolutionary patterns and processes: Paleobiology, v. 26, no. 4, p. 707-733.

Alroy, J., 2003a, A quantitative North American mammalian time scale: http://www.nceas.ucsb.edu/ alroy/timescale.html.

Alroy, J., 2003b, Taxonomic inflation and body mass distributions in North American fossil mammals: Journal of Mammalogy, v. 84, p. 431-443.

Alroy, J., Koch, P.L., and Zachos, J.C., 2000, Global climate change and North American mammalian evolution: Paleobiology, v. 26, no. 4, p. 259-288.

Aitchison, J. and Brown, J.A.C., 1957, The log-normal distribution: Cambridge, Cambridge University Press.

Barkstrom, B. R., Harrison, E. F., and Lee, R. B. ,1990, Earth radiation budget experiment: preliminary seasonal results. EOS Transactions, American Geophysical Union, v. 71. 
Barnosky, A. D., 2001, Distinguishing the effects of the Red Queen and Court Jester on Miocene mammal evolution in the northern Rocky Mountains: Journal of Vertebrate Paleontology, v. 21, no. 1, p. 172-185.

Barry, J. C., Morgan, M.E., Flynn, L.J., Pilbeam, D., Behrensmeyer, A.K., Raza, S.M, Khan, I.A., Badgley, C., Hicks, J., and Kelley, J., 2002, Faunal and environmental change in the late Miocene Siwaliks of northern Pakistan: Paleobiology, v. 28, no. 2, p. 1-71.

Barry, R.G., and Chorely, R.J., 1992, Atmosphere, weather, and climate, $6^{\text {th }}$ ed., New York, Routledge, $421 \mathrm{p}$.

Beard, J. S., 1976, The progress of plant succession on the Sufriére of St. Vincent: observations in 1972: Vegetatio, v. 31, p. 69-77.

Beeson, M. H., and Tolan, T.L., 1987, Columbia River Gorge: the geologic evolution of the Columbia River in northwestern Oregon and southwestern Washington: Geological Society of America Centennial Field Guide - Cordilleran Section, p. 321-326.

Behrensmeyer, A. K., 1988, Vertebrate preservation in fluvial channels: Palaeogeography, Palaeoclimatology, Palaeoecology, v. 63, p. 183-199.

Behrensmeyer, A. K., Western, D., and Deschant-Boaz, D.E., 1979, New perspectives in vertebrate paleoecology from a recent bone assemblage: Paleobiology, v. 5, no. 1, p. $12-21$.

Behrensmeyer, A. K., Kidwell, S.M., and Gastaldo, R.A., 2000, Taphonomy and paleobiology: Paleobiology, v. 26, no. 4, p. 103-147. 
Bennett, K. D., 1990, Milancovich cycles and their effects on species in ecological and evolutionary time: Paleobiology, v. 16, no. 1, p. 11-12.

Beranek, L. P., Link, P. K., and Fanning, C. M., 2006, Miocene to Holocene landscape evolution of the western Snake River Plain region, Idaho: using the SHRIMP detrital zircon provenance record to track eastward migration of the Yellowstone hotspot: Geological Society of America Bulletin, v. 118, no. 9-10, p. 1027-1050.

Berggren, W. A., and van Couvering, J.A., 1974, The late Neogene: developments in paleontology and stratigraphy, v. 2: Amsterdam, Elsevier, 216 p.

Bestland, E. A., Hammond, P.E., Blackwell, D.L.S., Retallack, G.J., and Stimac, J., 1999, Geologic framework of the Clarno Unit, John Day Fossil Beds National Monument, central Oregon: Oregon Geology, v. 61, no. 1, p. 3-19.

Betts, A.K., and Ball, J.H., 1997, Albedo over the boreal forest: Journal of Geophysical Research, v. 102, p. 901-928.

Bloch, J. I., Rose, K. D., and Gingerich, P. D., 1998, New species of Batodonoides (Lipotyphla, Geolabididae) from the early Eocene of Wyoming: smallest known mammal?: Journal of Mammalogy, v. 79, no. 3, p. 804-827.

Bluman, A. G., 2004, Elementary statistics: New York, McGraw-Hill, 810 p.

Botta, A., and Foley, J.A., 2002, Effects of climate variability and disturbances on the Amazonian terrestrial ecosystems dynamics: Global Biogeochemical Cycles, v. 16, no. 4, p. 1070-1081.

Bowers, J. E., Turner, R.M., and Burgess, T.L., 2004, Temporal and spatial patterns in emergence and early survival of perennial plants in the Sonoran Desert: Plant Ecology, v. 172, p. 107-119. 
Bromham, L., and Cardillo, M., 2007, Primates follow the 'island rule': implications for interpreting Homo floresiensis: Biology Letters, v. 3, p. 398-400.

Brown, J. H., 1971, Mammals on mountaintops: nonequilibrium insular biogeography: The American Naturalist, v. 105, no. 945, p. 467-478.

Brown, J. H., 1995, Macroecology: Chicago, The University of Chicago Press, 269 p.

Brown, J. H., and Nicoletto, P.F., 1991, Spatial scaling of species composition: body masses of North American land mammals: The American Naturalist, v. 138, no. 6, p. $1478-1512$.

Brown, J. H., Marquet, P.A., and Taper, M.L., 1993, Evolution of body size: consequences of an energetic definition of fitness: The American Naturalist, v. 142 , p. $573-584$.

Buechler, W. K., Dunn, M.T., and Rember, W.C., 2007, Late Miocene Pickett Creek Flora of Owyhee County, Idaho: Contributions from the Museum of Paleontology, The University of Michigan, v. 31, no. 12, p. 305-362.

Burnham, R., 1994, Plant deposition in modern volcanic environments: Transactions of the Royal Society, Edinburgh: Earth Science, v. 84, p. 275-281.

Burnham, R.J., Wing, S.L., and Parker, G.G., 1992, The reflection of deciduous forest communities in leaf litter: implications for autochthonous litter assemblages from the fossil record: Paleobiology, v. 18, p. 30-49.

Bursik, M. I., and Woods, A.W., 1996, The dynamics and thermodynamics of large ash flows: Bulletin of Volcanology, v. 58, p. 175-193. 
Camp, V. E., and Ross, M.E., 2004, Mantle dynamics and genesis of mafic magmatism in the intermontane Pacific Northwest: Journal of Geophysical Research, v. 109, p. 1-14.

Camp, V. E., Ross, M. E., and Hanson, W. E., 2003, Genesis of flood basalts and Basin and Range volcanic rocks from Steens Mountain to the Malheur River Gorge, Oregon: Geological Society of America Bulletin, v. 115, no. 1, p. 105-128.

Carney, D. A., and Page, L.M., 1990, Meristic characteristics and zoogeography of the genus Ptychocheilus (Teleostei: Cyprinidae): Copeia, v. 1990, no. 1, p. 171-181.

Carrasco, M. A., Kraatz, B.P., Davis, E.D., and Barnosky, A.D., 2005, Miocene mammal mapping project (MIOMAP), University of California Museum of Paleontology http:/www.ucmp.berkeley.edu/miomap/.

Carson, H.L., and Templeton, A.R., 1984, Genetic revolutions in relation to speciation phenomena and the founding of new populations: Annual Review in Ecology and Systematics, v. 15, p. 97-132.

Cathers, S. M., Dunbar, N.W., McDowell, F.W., McIntosh, W.C., and Scholle, P.A., 2010, Climate forcing by iron fertilization from repeated ignimbrite eruptions: the icehouse-silicic large igneous province (SLIP) hypothesis: Geosphere, v. 5, p. 315-324.

Chapin III, F. S., Walker, L.R., Fastie, C.L., and Sharman, L.C., 1994, Mechanisms of primary succession following deglaciation at Glacier Bay, Alaska: Ecological Monographs, v. 64, no. 2, p. 149-175. 
Childress, W., Crisafulli, C., and Rykiel, E., 1998, Comparison of Markovian matrix models of a primary successional plant community: Ecological Modelling, v. 107, p. 93-102.

Chown, S. L., and Gaston, K.J., 1997, The species-body size distribution: energy, fitness, and optimality: Functional Ecology, v. 11, p. 365-375.

Christiansen, P., 2004, Body size in proboscideans, with notes on elephant metabolism: Zoological Journal of the Linnean Society, v. 140, no. 4, p. 523-549.

Church, D. M., Goodstadt, L., Hillier, L. D. W., Zody, M. C., Goldstein, S., She, X., Bult, C. J., Agarwala, R., Cherry, J. L., and DiCuccio, M., 2009, Lineage-specific biology revealed by a finished genome assembly of the mouse: PLoS Biology, v. 7, no. 5, p. 1-16.

Clements, F. E., 1916, Plant succession: an analysis of the development of vegetation: Washington, D.C., Carnegie Institution of Washington, $512 \mathrm{p.}$

Coffin, D. P., and Lauenroth, W.K., 1990, A gap dynamics simulation model of succession in a semiarid grassland: Ecological Modelling, v. 49, p. 229-266.

Connell, J. H., 1978, Diversity in tropical rain forests and coral reefs: Science, v. 199, no. 4335, p. 1302-1310.

Conrey, R. M., Grunder, A.L., and Schmidt, M.E., 2004, SOTA field trip guide - state of the Cascade arc: stratocone persistence, mafic lava shields, and pyroclastic volcanism associated with intra-arc rift propagation: DOGAMI Open File Report O-04-04. 
Cooper, S. V., Lesica, P., and Kudray, G.M., 2007, Post-fire recovery of Wyoming Big Sagebrush Shrub-steppe in central and southeast Montana: United States Department of the Interior, Bureau of Land Management, State Office, p. 1-16.

Cope, E. D., 1887, The origin of the fittest: New York, Appleton, 467 p.

Cousens, B., Prytulak, J., Henry, C., Alcazar, A., and Brownrigg, T., 2008, Geology, geochronology, and geochemistry of the Miocene-Pliocene Ancestral Cascades arc, northern Sierra Nevada, California and Nevada: the roles of the upper mantle, subducting slab, and the Sierra Nevada lithosphere: Geosphere, v. 4, no. 5, p. 829853.

Coyne, J. A., and Orr, H.A., 2004, Speciation: Sunderland, MA, Sinauer Associates, Inc., $545 \mathrm{p}$.

Crisafulli, C. M., MacMahon, J. A., and Parmenter, R. R., 2005a, Small-mammal survival and colonization on the Mount St. Helens volcano: 1980-2002, in Dale, V. H., Swanson, F.J., and Crisafulli, C.M., ed., Ecological responses to the 1980 eruption of Mount St. Helens: New York, Springer, p. 199-218.

Crisafulli, C. M., Swanson, F. J., and Dale, V. H., 2005b, Overview of Ecological Responses to the Eruption of Mount St. Helens: 1980-2005, in Dale, V. H., Swanson, F.J., and Crisafulli, C.M., ed., Ecological Responses to the 1980 Eruption of Mount St. Helens: New York, Springer, p. 287-299.

Cross, A. T., and Taggart, R.E., 1982, Causes of short-term sequential changes in fossil plant assemblages; some considerations based on a Miocene flora of the Northwest United States: Annals of the Missouri Botanical Garden, v. 69, p. 679734. 
Cummings, M. L., 1991, Geology of the Deer Butte Formation, Malheur county, Oregon: faulting, sedimentation and volcanism in a post-caldera setting: Sedimentary Geology, v. 74, no. 1-4, p. 345-362.

Cummings, M. L., Evans, J. G., Ferns, M. L., and Lees, K. R., 2000, Stratigraphic and structural evolution of the middle Miocene synvolcanic Oregon-Idaho graben: Geological Society of America Bulletin, v. 112, no. 5, p. 668-682.

Dalrymple, G. B., 1979, Critical tables for conversion of K-Ar ages from old to new constants: Geology, v. 7, no. 11, p. 558.

Damuth, J., 1982, Analysis of the preservation of community structure in assemblages of fossil mammals: Paleobiology, v. 8, no. 4, p. 434-446.

Damuth, J., 1990, Problems in estimating body masses of archaic unglates using dental measurements, in Damuth, J., and MacFadden, B.J., ed., Body size in mammalian paleobiology: estimation and biological implications: Cambridge, Cambridge University Press, p. 229-253.

del Moral, R., 1998, Early succession on lahars spawned by Mount St. Helens: American Journal of Botany, v. 85, no. 6, p. 820-828.

del Moral, R., and Grishin, S.Y., 1999, Volcanic disturbances and ecosystem recovery, in Walker, L. R., ed., Ecosystems of disturbed ground: Amsterdam, Elsevier, p. 137160.

del Moral, R., and Lacher, I. L., 2005, Vegetation patterns 25 years after the eruption of Mount St. Helens, Washington, USA: American Journal of Botany, v. 92, no. 12, p. 1948-1956. 
Dobzhansky, T. G., 1937, Genetics and the origin of species: New York, Columbia University Press, 410 p.

Downing, K. F., 1992, Biostratigraphy, taphonomy, and paleoecology of vertebrates from the Sucker Creek Formation (Miocene) of southeastern Oregon [PhD thesis]: University of Arizona, $485 \mathrm{p}$.

Downing, K. F., and Swisher, C.C., III, 1993, New ${ }^{40} \mathrm{Ar} /{ }^{39} \mathrm{Ar}$ dates and refined geochronology of the Sucker Creek Formation, Oregon: Journal of Vertebrate Paleontology, v. 13, no. 3, p. 33A.

du Bray, E. A., John, D. A., Sherrod, D. R., Evarts, R. C., Conrey, R. M., and Lexa, J., 2006, Geochemical database for volcanic rocks of the western Cascades, Washington, Oregon, and California: U.S. Geological Survey Data Series 155, p. 49.

Eldredge, N., 2003, The sloshing bucket: how the physical realm controls evolution, in Crutchfield, J., and Schuster, P., ed., Evolutionary dynamics: exploring the interplay of selection, accident, neutrality, and function (SFI Studies in the Sciences of Complexity Series: New York, Oxford University Press, p. 3-32.

Eldredge, N., and Gould, S.J., 1972, Punctuated equilibria: an alternative to phyletic gradualism, in Schopf, T. J. W., ed., Models in paleobiology: San Francisco, Freeman, Cooper, and Co., p. 82-115.

Erwin, D.H., and Anstey, R.L., 1995, Introduction, in Erwin, D.H., and Anstey, R.L., ed., New appraoches to speciation in the fossil record: New York, Columbia University Press, p. 1-10. 
Evans, J. G., 1990, Geology and mineral resources map of the Jonesboro Quadrangle, Malheur County, Oregon: Oregon Department of Geology and Mineral Industries Geological Map Series GMS-66, scale 1:24000.

Everenden, J. F., and James, G. T., 1964, Potassium-argon dates and the Tertiary floras of North America: American Journal of Science, v. 262, no. 8, p. 945-974.

Farooqui, S. M., Bunker, R.C., Thoms, R.C., Clayton, D.C., and Bela, J.L., 1981, PostColumbia River Basalt Group stratigraphy and map compilation of the Columbia Plateau, Oregon: Oregon Department of Geology and Mineral Industries River system on the Columbia Plateau of Washington State: Richland, WA, Rockwell Hanford Operations Report RHO-BWI-SA-318, p. 47.

Fecht, K. R., Reidel, S.P., and Tallman, A.M., 1987, Paleodrainage of the Columbia River system on the Columbia Plateau of Washington state-a summary: Washington Division of Geology and Earth Resources Bulletin, v. 77, p. 219-248.

Fenner, M., and Thompson, K., 2005, The ecology of seeds: Cambridge, Cambridge University Press, 250 p.

Fisher, R. V., and Rensberger, J. M., 1972, Physical stratigraphy of the John Day formation, central Oregon: University of California Publications in Geological Sciences: Berkeley, CA, University of California Press, 45 p.

Fitz, H.C., DeBellevue, E.B., Costanza, R., Boumans, R., Maxwell, T., Waigner, L., Sklar, F.H., 1996, Development of a general ecosystem model for a range of scales and ecosystems: Ecological Modelling, v. 88, p. 263-295.

Foote, M., and Raup, D.M., 1996, Fossil preservation and the stratigraphic ranges of taxa: Paleobiology, v. 22, no. 2, p. 121-140. 
Fremd, T. J., Bestland, E.A., and Retallack, G.J., 1994, John Day basin field guide and road log for Society of Vertebrate Paleontology Annual Meeting: Seattle, Northwest Interpretative Association, 80 p.

Fuentes, M.A. and Kuperman, M.N., 1999, Cellular automata and epidemiological models with spatial dependence: Physica A: Statistical and Theoretical Physics, v. 267, no. 3-4, p. 471-486.

Fuller, D.O., and Ottake, C., 2002, Land cover, ranifall, and land-surface albedo in west Africa: Climate Change, v. 54, p. 181-204.

Futuyama, D. J., 1987, On the role of species anagenesis: The American Naturalist, v. 130, p. 465-473.

Gardezi, T., and deSilva, J., 1999, Diversity in relation to body size in mammals: a comparative study: The American Naturalist, v. 153, p. 110-123.

Gavrilets, S., 1999, A dynamical theory of speciation on holey adaptive landscapes: The American Naturalist, v. 154, p. 1-22.

Gavrilets, S., 2004, Fitness landscapes and the origin of species: Princeton, NJ, Princeton University Press, Monographs in Population Biology, 476 p.

Gersani, M., Brown, J., O'Brien, E. E., Maina, G. M., and Abramsky, Z., 2001, Tragedy of the commons as a result of root competition: Journal of Ecology, v. 89, no. 4, p. 660-669.

Gibson, D.J., Ely, J.S., and Looney, P.B., 1997, A Markovian approach to modeling succession on a coastal barrier island following beach nourishment: Journal of Coastal Research, v. 13, p. 831-841. 
Gleason, H. A., 1926, The individualistic concept of the plant association: Bulletin of the Torry Botanical Club, v. 53, p. 7-26.

Glen-Lewin, D.C. and van der Maarel, E., 1992, Patterns and processes in vegetation dynamics, in Glen-Lewin, D.C., Peet, R.K., and Veblen, T.T., ed., Plant succession: theory and prediction, London, Chapman and Hall, p. 11-59.

Gould, S. J., 1977, Ontongeny and phylogeny: Cambridge, MA, The Belknap Press of Harvard University Press, 501 p.

Gould, S.J., 1989, Wonderful life: the Burgess Shale and the nature of history: New York, W.W. Norton \& Company, 347 p.

Gould, S. J., 2002, The structure of evolutionary theory: Cambridge, MA, The Belknap Press of Harvard University Press, 1433 p.

Gould, S. J., and Eldredge, N., 1993, Punctuated equilibrium comes of age: Nature, v. 366, p. 223-227.

Graham, R. W., and Grimm, E. C., 1990, Effects of global climate change on the patterns of terrestrial biological communities: Trends in Ecology \& Evolution, v. 5, no. 9, p. 289-292.

Greene, R. C., 1973, Petrology of the welded tuff of Devine Canyon, southeastern Oregon: United States Geological Survey Professional Paper 729, p. 26.

Grime, J. P., 1973, Competitive exclusion in herbaceous vegetation: Nature, v. 242, p. 344-347.

Guo, Q., 2004, Slow recovery in desert perennial vegetation following prolonged human disturbance: Journal of Vegetation Science, v. 15, p. 757-762. 
Gutschick, V.P., and BassiriRad, H., 2003, Extreme events as shaping physiology, ecology, and evolution of plants: toward a unified definition and evaluation of their consequences: New Phytologist, v. 160, p. 21-42.

Gutschick, V.P., and BassiriRad, H., 2007, Biological extreme events: a research framework: EOS, Transactions, American Geophysical Union, v. 91, no. 9, p. 8586.

Hales, T. C., Abt, D.L., Humphreys, E.D., and Roering, J.J., 2005, A lithospheric instability origin for Columbia River flood basalts and Wallowa Mountains uplift in northeast Oregon: Nature, v. 438, p. 842-845.

Hanser, S. E., and Huntley, N. J., 2006, The biogeography of small mammals of fragmented sagebrush-steppe landscapes: Journal of Mammalogy, v. 87, no. 6, p. 1165-1174.

Hershler, R., and Liu, H. P., 2004, A molecular phylogeny of aquatic gastropods provides a new perspective on biogeographic history of the Snake River region: Molecular Phylogenetics and Evolution, v. 32, no. 3, p. 927-937.

Horn, H. S., 1975, Markovian properties of forest succession, in Cody, M. L., and Diamond, J.M., ed., Ecology and evolution of communities: Cambridge, MA, Harvard University Press, p. 196-211.

Huffman, G. J., Adler, R.F. , Arkin, P.A. , Chang, A. , Ferraro, R., Gruber, A., Janowiak, J., Joyce, R.J. , McNab, A., Rudolf, B. , Schneider, U. , and Xie, P., 1997, The global precipitation climatology project (GPCP) combined precipitation data set. Bulletin of the American Meteorological Society, v. 78, p. 5-20. 
Hunt Jr, R. M., and Stepleton, E., 2004, Geology and paleontology of the upper John Day beds, John Day River Valley, Oregon: lithostratigraphic and biochronologic revision in the Haystack Valley and Kimberly areas (Kimberly and Mt. Misery quadrangles): Bulletin of the American Museum of Natural History, v. 282, p. 190.

Huston, M., and Smith, T., 1987, Plant succession: life history and competition: The American Naturalist, v. 130, no. 2, p. 168-198.

Huxley, J. S., 1942, Evolution, the modern synthesis: London, Allen and Unwin, 645 p.

Janis, C. M., 1990, Correlation of cranial and dental variables with body size in ungulates and macropodoids, in Damuth, J., and MacFadden, B.J., ed., Body size in mammalian paleobiology: estimation and biological implications: Cambridge, Cambridge Univ Press, p. 255-300.

Janis, C. M., Scott, K. M., and Jacobs, L. L., 1998, Evolution of Tertiary mammals of North America: volume I, terrestrial carnivores, ungulates, and ungulatelike mammals: Cambridge, Cambridge Univ Press, 701 p.

Janis, C. M., Gunnell, G. F., and Uhen, M. D., 2008, Evolution of Tertiary mammals of North America: volume II, small mammals, Xenarthrans, and marine mammals: Cambridge, Cambridge University Press, 795 p.

Johnson, J. A., Binger, G.B., Hooper, P.R., and Hawkesworth, C.J., 1996, Implications of structure and stratigraphy in the Juntura area, east-central Oregon: Geological Society of America Abstracts with Programs, v. 28, no. 5, p. 78.

Johst, K., and Brandl, R., 1997, Body size and extinction risk in a stochastic environment: Oikos, v. 78, no. 3, p. 612-617. 
Jones, M. C., 1983, The projection pursuit algorithm for exploratory data analysis $[\mathrm{PhD}$ thesis]: University of Bath.

Jones, M. T., Sparks, S.J., and Valdes, P.J., 2007, The climatic impact of supervolcanic ash blankets: Climate Dynamics, v. 29, p. 553-564.

Kellogg, K. S., Harlan, S.S., Mehnert, H.H., Snee, L.W., Pierce, K.L., Hackett, W.R., and Rodgers, D.W., 1994, Major 10.2-Ma rhyolitic volcanism in the eastern Snake River Plain, Idaho - isotopic age and stratigraphic setting of the Arbon Valley Tuff Member of the Starlight Formation: U.S. Geological Survey Bulletin 2091, $81 \mathrm{p}$.

Kimmel, P. G., 1982, Stratigraphy, age, and tectonic setting of the Miocene-Pliocene lacustrine sediments of the western Snake River Plain, Oregon and Idaho, in Bonnichsen, B., and Breckenridge, R.M., ed., Cenozoic Geology of Idaho: Idaho Bureau of Mines and Geology Bulletin 26, p. 139-153.

Kohn, M. J., and Fremd, T.J., 2007, Tectonic controls on isotope compositions and species diversification, John Day Basin, central Oregon: PaleoBios, v. 27, no. 2, p. $48-61$.

Kohn, M. J., and Dettman, D. L., 2007, Paleoaltimetry from stable isotope compositions of fossils, in Kohn, M. J., ed., Paleoaltimetry: geochemical and thermodynamic approaches: Chantilly, VA, Mineral Society of America, p. 119-154.

Kohn, M. J., and Law, J. M., 2006, Stable isotope chemistry of fossil bone as a new paleoclimate indicator: Geochimica et Cosmochimica Acta, v. 70, no. 4, p. 931946. 
Kohn, M. J., Miselis, J.L., and Fremd, T.J., 2002, Oxygen isotope evidence for progressive uplift of the Cascade Range, Oregon: Earth and Planetary Science Letters, v. 204, p. 151-165.

Kondrashov, A. S., 2003, Accumulation of Dobzhansky-Muller incompatibilities within a spatially structured population: Evolution, v. 57, no. 1, p. 151-153.

Kozu, S., 1934, The great activity of Komagatake in 1929: Minerologische und Petrographische Mitteilungen, v. 45, p. 133-174.

Lawrence, R.J., 1988, The log-normal as event-time distribution, in Crow, E.L. and Shimizu, K, ed., Log-normal distributions: theory and application, New York: Dekker, P. 211-228.

Legendre, S., 1986, Analysis of mammalian communities from the late Eocene and Oligocene of southern France: Palaeovertebrata, v. 16, no. 4, p. 191-212.

Legendre, S., and Roth, C., 1988, Correlation of carnassial tooth size and body weight in recent carnivores (Mammalia): Historical Biology, v. 1, no. 1, p. 85-98.

Levins, R., 1968, Evolution in changing environments: Princeton, Princeton University Press, $120 \mathrm{p}$.

Link, P. K., McDonald, H. G., Fanning, C. M., and Godfrey, A. E., 2002, Detrital zircon evidence for Pleistocene drainage reversal at Hagerman Fossil Beds National Monument, central Snake River Plain, Idaho, in Bonnichsen, B., White, C.M., and McCurry, M., ed., Tectonic and magmatic evolution of the Snake River Plain Volcanic Province: Idaho Geological Survey Bulletin 30, p. 105-119. 
Liow, L. H., Fortelius, M., Bingham, E., Lintulaakso, K., Mannila, H., Flynn, L., and Stenseth, N.C., 2008, Higher origination and extinction rates in larger mammals: Proceedings of the National Academy of Sciences, v. 105, no. 16, p. 6097-6102.

Lister, A. M., 1989, Rapid dwarfing of red deer on Jersey in the last interglacial: Nature, v. 342 , p. $539-542$.

Lomolino, M. V., 1985, Body size of mammals on islands: the island rule re-examined: The American Naturalist, v. 125, p. 310-316.

Lomolino, M. V., 2005, Body size evolution in insular vertebrates: generality of the island rule: Journal of Biogeography, v. 32, p. 1683-1699.

Losos, J. B., and Ricklefs, R.E., 2009, Adaptation and diversification on islands: Nature, v. 457, p. $830-836$.

Louys, J., 2007, Limited effect of the Quaternary's largest super-eruption (Toba) on land mammals from southeast Asia: Quaternary Science Reviews, v. 26, p. 3108-3117.

Louys, J., Curnoe, D., and Tong, H., 2007, Characteristics of Pleistocene megafauna extinctions in southeast Asia: Palaeogeography, Palaeoclimatology, Palaeoecology, v. 243, p. 152-173.

Lovegrove, B. G., and Haines, L., 2004, The evolution of placental mammal body sizes: evolutionary history, form, and function: Oecologia, v. 138, p. 13-27.

Lyman, R. L., 1994, Vertebrate taphonomy: Cambridge, Cambridge University Press, $524 \mathrm{p}$.

Lynch, M., and Force, A. G., 2000, The origin of interspecific genomic incompatibility via gene duplication: The American Naturalist, v. 156, p. 590-605. 
Lyons, S. K., Smith, F.A., and Brown, J.H., 2004, Of mice, mastodons, and men: humanmediated extinctions on four continents: Evolutionary Ecology Research, v. 6, p. 339-358.

MacFadden, B. J., and Hulbert Jr, R. C., 1990, Body size estimates and size distribution of ungulate mammals from the Late Miocene Love Bone Bed of Florida, in Damuth, J., and MacFadden, B.J., ed., Body size in mammalian paleobiology: estimation and biological implications: Cambridge, Cambridge University Press, p. 337-363.

Manville, V., 2002, Sedimentary and geomorphic responses to ignimbrite emplacement: readjustment of the Waikato River after the A.D. 181 Taupo Eruption, New Zealand: The Journal of Geology, v. 110, p. 519-541.

Marquet, P. A., and Taper, M.L., 1998, On size and area: patterns of mammalian body size extremes across landmasses: Evolutionary Ecology, v. 12, p. 127-139.

Mayr, E., 1942, Systematics and the origin of species: New York, Columbia University Press, 334 p.

Mayr, E., 1954, Change of genetic environment and evolution, in Huxley, J. S., Hardy, C., and Ford, E.B., ed., Evolution as a process: London, Allen \& Unwin, p. 157180.

Mayr, E., 1963, Animal species and evolution: Cambridge, MA, Harvard University Press, 797 p.

Mayr, E., 1982, Adaptation and selection: Biologisches Zentrablatt, v. 101, p. 66-77. Mayr, E., 2001, What evolution is: New York, Basic Books, 318 p. 
McDonald, J.N., 1981, North American Bison: their classification and evolution: Berkeley, University of California Press, 316 p.

Meiri, S., Meijaard, E., Wich, S.A., Groves, C.P., and Helgen, M., 2008, Mammals of Borneo - small size on large island: Journal of Biogeography, v. 35, p. 1087-1094. Merriam, J. C., Stock, D., and Moody, C.L., 1925, The Pliocene Rattlesnake Formation and fauna of eastern Oregon, with notes on the geology of the Rattlesnake and Mascall deposits: The Carnegie Institute of Washington: Contributions to Paleontology, v. 347, p. 45-92.

Micheels, A., Bruch, A., Uhl, D., Utescher, T., and Mosbrugger, V., 2007, A late Miocene climate model simulation with ECHAM4/ML and its quantitative validation with terrestrial proxy data: Paleogeography, Palaeoclimatology, Palaeoecology, v. 253, p. 251-270.

Miller, R.F., and Rose, J.A., 1999, Fire history and western juniper encroachment in sage-brush steppe: Journal of Range Management, v. 52, p. 550-559.

Miller, T. F., 1990, A numerical model of volatile behavior in nonwelded cooling pyroclastic deposits: Journal of Geophysical Research, v. 95, no. B12, p. 19,34919,364.

Millien, V., 2006, Morphological evolution is accelerated among island mammals: PLoS Biology, v. 4, no. 10, p. 1863-1868.

Minckley, C. L., Hendrickson, D.A., and Bond, C.E., 1986, Geography of western North American freshwater fishes: description and relationships to intercontinental tectonism, in Hocutt, C. H., and Wiley, E.O., ed., The zoogeography of North American freshwater fishes: New York, John Wiley \& Sons, p. 519-613. 
Mokany, K., Raison, R. J., and Prokushkin, A. S., 2005, Critical analysis of root: shoot ratios in terrestrial biomes: Global Change Biology, v. 12, no. 1, p. 84-96.

Morgan-Richards, M., Trewick, S. A., and Wallis, G. P., 2000, Characterization of a hybrid zone between two chromosomal races of the weta Hemideina thoracica following a geologically recent volcanic eruption: Heredity, v. 85, no. 6, p. 586592.

Mortimer, N., and Coleman, R. G., 1985, A Neogene structural dome in the Klamath Mountains, California and Oregon: Geology, v. 13, no. 4, p. 253-256.

Mousseau, T. A., and Roff, D.A., 1987, Natural selection and the heritability of fitness components: Heredity, v. 59, p. 181-197.

Munns, W.R., Gervais, J.A., Hoffman, A.A., Hommen, U., Nacci, D.E., Nakamaru, M., Sibly, R.M., and Topping, C.J., 2007, Modeling approaches to population-level risk assessment, in Barnthouse, R.W., Munns, W.R., and Sorenson, M.T., ed., Population-level ecological risk assessment: Pansacola, FL, SETAC Press, p.179210.

Muller, H. J., 1939, Reversibility in evolution considered from the standpoint of genetics: Biological Reviews of the Cambridge Philosophical Society, v. 14, no. 3, p. 261280.

Muller, H. J., 1940, Bearings of the Drosophila work on systematics, in Huxley, J. S., ed., The new systematics: Oxford, The Clarendon Press, p. 185-268.

Muller, H. J., 1942, Isolating mechanisms, evolution and temperature: Biological Symposium, p. 71-125. 
Odenbaugh, J., 2005, The "structure" of population ecology: philosophical reflections on unstructured and structured models, in Beisner, B.E., and Cuddington, K., ed., Ecological paradigms lost: routes to theory change: Academic Press, Elsevier, p. $62-80$.

Oesterheld, M., Loreti, J., Semmartin, M., and Paruelo, J. M., 1999, Grazing, fire, and climate effects on primary productivity of grasslands and savannas, in Walker, L. R., ed., Ecosystems of disturbed ground: Amsterdam, Elsevier, p. 287-306.

Orr, E. L., Orr, W. N., and Baldwin, E. M., 1999, Geology of Oregon: Dubuque, IA, Kendall/Hunt Publishing Company, 268 p.

Orr, H. A., 1995, The population genetics of speciation: the evolution of hybrid incompatabilities: Genetics, v. 139, p. 1805-1813.

Orr, H. A., and Turelli, M., 2001, The evolution of postzygotic isolation: accumulating Dobzhansky-Muller incompatibilities: Evolution, v. 55, no. 6, p. 1085-1094.

Overpeck, J. T., Webb, R. S., and Webb Iii, T., 1992, Mapping eastern North American vegetation change of the past $18 \mathrm{ka}$ : no-analogs and the future: Geology, v. 20, no. 12 , p. $1071-1074$.

Pérez, C. A., and Frangi, J. L., 2000, Grassland biomass dynamics along an altitudinal gradient in the Pampa: Journal of Range Management, v. 53, no. 5, p. 518-528.

Perkins, M. E., Brown, F. H., Nash, W. P., Williams, S. K., and McIntosh, W., 1998, Sequence, age, and source of silicic fallout tuffs in middle to late Miocene basins of the northern Basin and Range province: Geological Society of America Bulletin, v. 110, no. 3, p. 344-360. 
Pezzopane, S. K., and Weldon, R. J., 1993, Tectonic role of active faulting in central Oregon: Tectonics, v. 12, no. 5, p. 1140-1169.

Pierce, K. L., and Morgan, L. A., 1992, The track of the Yellowstone hot spot: volcanism, faulting, and uplift: Regional geology of eastern Idaho and western Wyoming: Geological Society of America Memoir, v. 179, no. 322, p. 1-53.

Plotnick, R. E., and Gardner, R.H., 2002, A general model for simulating the effets of landscape heterogeneity and disturbance on community patterns: Ecological Modelling, v. 147, p. 171-197.

Prothero, D.R., 1999, Does climatic change drive mammalian evolution?: GSA Today, v. 9, no. 9 , p. 1-5.

Prothero, D.R., 2004, Did impacts, volcanic eruption, or climate change affect mammalian evolution?: Palaeogeography, Palaeoclimatology, Palaeoecology, v. 214, p. 283-294.

Prothero, D. R., and Davis, E.B., 2008, Magnetic stratigraphy of the upper Miocene (early Hemphillian) Thousand Creek Formation, northwestern Nevada, in Lucas, S. G., Morgan, G.S., Speilmann, J.A., and Prothero, D.R., ed., Neogene Mammals: New Mexico Museum of Natural History and Science Bulletin 44: Albuquerqe, NM, New Mexico Museum of Natural History and Science, a Division of the Department of Cultural Affairs, p. 233-237.

Prothero, D. R., Draus, E., and Foss, S.E., 2006a, Magnetic stratigraphy of the lower portion of the middle Miocene Mascall Formation, central Oregon: PaleoBios, v. 26, p. 37-42. 
Prothero, D. R., Hoffman, J.M., and Foss S.E., 2006b, Magnetic stratigraphy of the upper Miocene (Hemphillian) Rattlesnake Formation, central Oregon: PaleoBios, v. 26, no. 1, p. 31-35.

Raia, P., and Meiri, S., 2006, The island rule in large mammals: paleontology meets ecology: Evolution, v. 60, no. 8, p. 1730-1742.

Rampino, M., and Self, S., 1992, Volcanic winter and accelerated glaciation following the Toba super-eruption: Nature, v. 359, p. 50-52.

Rampino, M., and Self, S., 1993, Climate-volcanism feedback and the Toba eruption of 74000 years ago: Quaternary Research, v. 40, p. 269-280.

Reiners, P. W., Ehlers, T. A., Garver, J. I., Mitchell, S. G., Montgomery, D. R., Vance, J. A., and Nicolescu, S., 2002, Late Miocene exhumation and uplift of the Washington Cascade Range: Geology, v. 30, no. 9, p. 767-770.

Rensch, B., 1947, Neuere probleme der abstammunglehre: die transspezificshe evolution: Stuttgart, F. Enke, 407 p.

Repenning, C. A., Weasma, T. R., and Scott, G. R., 1995, The early Pleistocene (latest Blancan-earliest Irvingtonian) Froman Ferry fauna and history of the Glenns Ferry Formation, southwestern Idaho: U.S. Geological Survey Bulletin 2105, 86 p.

Retallack, G. J., 1988, Down-to-Earth approaches to vertebrate paleontology: PALAIOS, v. 3 , no. 3 , p. $335-344$.

Retallack, G.J., 2004, Late Miocene climate and life on land in Oregon within a context of Neogene global change: Paleogeography, Palaeoclimatology, Palaeoecology, v. 214, p. 97-123. 
Retallack, G.J., 2007, Cenozoic paleoclimate on land in North America: Journal of Geology, v. 115, p. 271-294.

Retallack, G. J., Bestland, E.A., and Fremd, T.J., 1996, Reconstructions of Eocene and Oligocene plants and animals of central Oregon: Oregon Geology, v. 58, no. 3, p. $51-69$.

Retallack, G. J., Tanaka, S., and Tate, T., 2002, Late Miocene advent of tall grassland paleosols in Oregon: Palaeogeography, Palaeoclimatology, Palaeoecology, v. 183, p. $329-354$.

Retallack, G.J., Wynn, J.G., and Fremd, T.J., 2004, Glacial-interglacial-scale paleoclimatic change without large ice sheets in the Oligocene of central Oregon: Geology, v. 32, no. 4, p. 297-300.

Riehle, J. R., 1973, Calculated compaction profiles of rhyolitic ash-flow tuffs: Geological Society of America Bulletin, v. 84, p. 2193-2216.

Riehle, J. R., Miller, T.F., and Bailey, R.A., 1995, Cooling, degassing and compaction of rhyolitic ash flow tuffs: a computational model: Bulletin of Volcanology, v. 57, p. 319-336.

Robinson, P. T., Walker, G. W., and McKee, E. H., 1990, Eocene (?), Oligocene, and lower Miocene rocks of the Blue Mountains region: Geology of the Blue Mountains region of Oregon, Idaho, and Washington: Cenozoic geology of the Blue Mountains region: US Geological Survey Professional Paper, v. 1437, p. 2961.

Rosenzweig, M. L., 1968, Net primary productivity of terrestrial communities: prediction from climatological data: The American Naturalist, v. 102, no. 923, p. 67-74. 
Rundle, H. D., 2003, Divergent environments and population bottlenecks fail to generate premating isolation in Drosphila pseudoobscura: Evolution, v. 57, no. 11, p. 25572565.

Rundle, H. D., Moores, A.O., and Whitlock, M.C., 1998, Single founder-flush events and the evolution of reproductive isolation: Evolution, v. 52, no. 6, p. 1850-1855.

Schaller, G. B., 1967, The deer and the tiger: a study of wildlife in India: Chicago, The University of Chicago Press, 370 p.

Schaller, G. B., 1972, The Serengeti Lion: a study of predator-prey relations: Chicago, The University of Chicago Press, 480 p.

Schmidt, N. M. and Jensen., P.M., 2003, Changes in mammalian body length over 175 years - adaptations to a fragmented landscape?: Conservation Ecology, v. 7, no. 2, p. 7 [online].

Schneider, E. D., and Kay, J.J., 1992, Life as a manifestation of the second law of thermodynamics: Mathematical and Computer Modelling, v. 19, no. 6-8, p. 25-48.

Sheppard, R. A., 1994, Zeolitic diagenesis of tuffs in miocene lacustrine rocks near Harney Lake, Harney County, Oregon: U.S. Geological Survey Bulletin 2108, 28

p.

Shreve, F., 1917, The establishment of desert perenials: Journal of Ecology, v. 5, no. 3-4, p. 210-216.

Silva, M., and Downing, J.A., 1995, CRC handbook of mammalian body masses: Boca Raton, CRC Press, 359 p. 
Silverman, B. W., 1981, Using kernel density estimates to investigate multimodality: Journal of the Royal Statistical Society, Series B (Methodological), v. 43, no. 1, p. 97-99.

Silverman, B. W., 1986, Density estimation for statistics and data analysis: London, Chapman and Hall, 175 p.

Simpson, G. G., 1944, Tempo and mode in evolution: New York, Columbia University Press, $237 \mathrm{p}$.

Singleton, E. S., and Oldow, J. S., 2004, Late Holocene deformation rates within the Alvord Basin, northwestern Great Basin, southwestern Oregon: Geological Society of America Abstracts with Programs, 28 p.

Smith, F. A., Brown, J.H., Haskell, J.P., Lyons, S.K., Alroy, J., Charnov, E.L., Dayan, T., Enquist, B.J., Ernest, S.K.M., Hadley, E.A., Jones, K.E., Kaufman, D.M., Marquet, P.A., Maurer, B.A., Niklas, K.J., Porter, W.P., Tiffney, B., and Willig, M.R., 2004, Similarity of mammalian body size across the taxonomic hierarchy and across space and time: The American Naturalist, v. 163, no. 5, p. 672-691.

Smith, G. A., 1986, Stratigraphy, sedimentology, and petrology of Neogene rocks of the Deschutes basin, central Oregon: a record of continental volcanism and its influence on fluvial sedimentation in an arc-adjacent basin [PhD thesis]: Oregon State University, $467 \mathrm{p}$.

Smith, G. A., 1988, Neogene synvolcanic and syntectonic sedimentation in central Washington: Geological Society of America Bulletin, v. 100, no. 9, p. 1479-1492. 
Smith, G. A., and Snee, L.W., 1984, Revised stratigraphy of the Deschutes basin, Oregon: implications for the Neogene development of the central Oregon Cascades [abstract]: EOS, Transactions of the American Geophysical Union, v. 35 , p. 330.

Solow, A. R., and Smith, W., 1997, On fossil preservation and the stratigraphic ranges of taxa: Paleobiology, v. 23, no. 3, p. 271-277.

Stebbins, G. L., 1950, Variation and evolution in plants: New York, Columbia University Press, $643 \mathrm{p}$.

Steppuhn, A., Micheels, A., Bruch, A., Geiger, G., and Mosbrugger, V., 2006, Reconstructing the late Miocene climate and ocean heat flux using AGCM ECHAM4 coupled to a mixed-layer ocean model with adjusted flux correction: Palaeogeography, Palaeoclimatology, Palaeoecology, v. 238, p. 399-423.

Steppuhn, A., Micheels, A., Bruch, A., Uhl, D., Utescher, T., and Mosbrugger, V., 2007, The sensitivity of ECHAM4/ML to a double $\mathrm{CO}^{2}$ scenario for the late Miocene and the comparison to terrestrial proxy data: Global and Planetary Change, v. 57, p. 189-212.

Streck, M. J., and Ferns, M., 2004, The Rattlesnake Tuff and other Miocene silicic volcanism in eastern Oregon, in Haller, K. M., and Wood, S.H., ed., Geological field trips in southern Idaho, eastern Oregon, and northern Nevada: Boise, Department of Geosciences, Boise State University, p. 1-17.

Streck, M. J., and Grunder, A.L., 1995, Crystallization and welding variations in a widespread ignimbrite sheet; the Rattlesnake Tuff, eastern Oregon, USA: Bulletin of Volcanology, v. 57, p. 151-169. 
Streck, M. J., and Grunder, A.L., 2008, Phenocryst-poor rhyolites of bimodel, tholeiitic provinces: the Rattlesnake Tuff and implications for mush extraction models: Bulletin of Volcanology, v. 70, no. 3, p. 385-401.

Swanson, F. J., Crisafulli, C. M., and Yamaguchi, D. K., 2005, Geological and ecological settings of Mount St. Helens before May 18, 1980, in Dale, V. H., Swanson, F.J., and Crisafulli, C.M., ed., Ecological responses to the 1980 eruption of Mount St. Helens: New York, Springer, p. 13-26.

Swisher III, C. C., $1992,{ }^{40} \mathrm{Ar} /{ }^{39} \mathrm{Ar}$ dating and its application to the calibration of the North American Land Mammal ages [PhD thesis]: University of California, Berkeley, 239 p.

Taggart, R. E., and Cross, A.T., 1990, Plant successions and interruptions in Miocene volcanic deposits, Pacific Northwest: Geological Society of America Special Paper 244, p. 57-68.

Taggart, R. E., and Cross, A. T., 1974, History of vegetation and paleoecology of upper Miocene Sucker Creek beds of eastern Oregon, in Symposium on Stratigraphical Palynology, p. 125-132.

Takenaka, A., 2006, Dynamics of seedling populations and tree species coexistence in a forest: a simulation study: Ecological Research, v. 21, p. 356-363. 
Tedford, R. H., Albright III, L. B., Barnosky, A. D., Ferrusquia-Villafranca, I., Hunt Jr, R. M., Storer, J. E., Swisher Iii, C. C., Voorhies, M. R., Webb, S. D., and Whistler, D. P., 2004, Mammalian biochronology of the Arikareean through Hemphillian interval (late Oligocene through early Pliocene epochs), in Woodburne, M. O., ed., Late Cretaceous and Cenozoic mammals of North America: biostratigraphy and geochronology: New York, Columbia University Press, p. 169-231.

Thayer, T. P., 1937, Petrology of later Tertiary and Quaternary rocks of the north-central Cascade Mountains in Oregon, with notes on similar rocks in western Nevada: Bulletin of the Geological Society of America, v. 48, no. 11, p. 1611-1652.

Tilman, D., 1985, The resource-ratio hypothesis of plant succession: The American Naturalist, v. 125 , no. 6, p. 827-852.

Topping, C.J., 1999, An individual-based model for dispersive spiders in agroecosystems: simulations of the effects of landscape structure: Journal of Arachnology, v. 27 p. 378-386.

Turner, M. G., and Dale, V. H., 1991, Modeling landscape disturbance, in Turner, M. G., and Gardener, R.H., ed., Ecological studies 82: quantitative methods in landscape ecology: New York, Springer-Verlag, p. 323-352.

van Dam, J. A., Abdul Aziz, H., Sierra, M.A.A., Hilgren, F.J., van den Hoek Ostende, L.W., Lourens, L.J, Mein, P., van der Meulen, A.J., and Palaez-Campomanes, P., 2006, Long-period astronomical forcing of mammal turnover: Nature, v. 443, p. 687-691. 
Vandergast, A.G., Gillespie, R.G., and Roderick, G.K., 2004, Influence of volcanic activity on the population genetic structure of Hawaiian Tetragnatha spiders: fragmentation, rapid population growth and the potential for accelerated evolution: Molecular Evolution, v. 13, p. 1729-1743.

Vrba, E. S., and DeGusta, D., 2004, Do species populations really start small? New perspectives from the late Neogene fossil record of african mammals:

Philisophical Transactions of the Royal Society, London, B, v. 359, p. 285-293.

Walker, G. W., 1979, Revisions to the Cenozoic stratigraphy of Harney Basin, Oregon: US Geological Survey Bulletin 1475, 35 p.

Walker, G. W., 1990, Miocene and younger rocks of the Blue Mountains region, exclusive of the Columbia River Basalt Group and associated mafic lava flows: Geology of the Blue Mountains region of Oregon, Idaho, and Washington: Cenozoic geology of the Blue Mountains region: US Geological Survey Professional Paper, v. 1437, p. 101-118.

Walker, L. R., and del Moral, R., 2003, Primary succession and ecosystem rehabilitation: Cambridge, Cambridge University Press, 442 p.

Waterston, R. H., Lindblad-Toh, K., Birney, E., Rogers, J., Abril, J. F., Agarwal, P., Agarwala, R., Ainscough, R., Alexandersson, M., and An, P., 2002, Initial sequencing and comparative analysis of the mouse genome: Nature, v. 420, p. 520-562.

Wheeler, H. E., and Cook, E. F., 1954, Structural and stratigraphic significance of the Snake River capture, Idaho-Oregon: The Journal of Geology, v. 62, no. 6, p. 525536. 
Whilmshurst, J. M., and McGlone, M.S., 1996, Forest disturbance in the central North Island, New Zealand, following the 1850 BP Taupo eruption: The Holocene, v. 6, p. 399-411.

White, M. J. D., 1945, Animal cytology and evolution: Cambridge, Cambridge University Press, 375 p.

Whittaker, R. J., Bush, M.B., and Richards, K., 1989, Plant recolonization and vegetation succession on the Krakatau Islands, Indonesia: Ecological Monographs, v. 59, no. 2, p. 59-123.

Wilkie, D., Morelli, G., Rotberg, F., and Shaw, E., 1999, Wetter isn't better: global warming and food security in the Congo Basin: Global Environmental Change, v. 9, no. 4, p. 323-328.

Wolfe, J. A., 1994, Tertiary climatic changes at middle latitudes of western North America: Palaeogeography, Palaeoclimatology, Palaeoecology, v. 108, p. 195205.

Wolfe, J. A., Schorn, H.E., Forest, C.E., and Molnar, P., 1997, Paleobotanical evidence for high altitudes in Nevada during the Miocene: Science, v. 276, no. 5319, p. 1672-1675.

Wood, D. M., and del Moral, R., 1987, Mechanisms of early primary succession in subalpine habitats on Mount St. Helens: Ecology, v. 68, no. 4, p. 780-790.

Wood, D.M., and Morris, W.F., 1990, Ecological constraints to seedling establishment on the pumice plains, Mount St. Helens, Washington: American Journal of Botany, v. 77 , no. 11 , p. $1411-1418$. 
Zeng, X., Rao, P., DeFries, R.S., and Hansen, M.C., 2003, Interannual variability and decadal trend in fractional vegetation cover from 1982-2000: Journal of Applied Meteorology, v. 42, p. 1525-1530. 
Appendix A. Creation of Figure 1

Patterns

Mammals are the chosen fossils to study and indicate changes in the ecosystems of the PNW (and more specifically the LMPN) since they are best preserved, most diverse, and most abundant. The data come from outcrops in formations ranging 45 $0.01 \mathrm{Ma}$ within a $400 \mathrm{~km}$ radius of the proposed caldera source for the RST near Capehart Lake, Oregon (Streck and Grunder, 1995).

\section{Data collection}

In order to reach a better understanding of the patterns of the temporal ranges of mammal species, data collection from multiple sources was conducted. Taxonomic range maps are typically generated with successive taxa on one axis and their temporal ranges on a second axis. However, in order to distinguish species as more than Latin nomenclature their physical attribute of mass was collected for one axis because of several revealing biases (e.g. sampling, preservation, genetic variation, and reproductive) it affords. Collecting data on body masses is tedious work since much data can be scattered or the regression and allometric equations used to estimate mass are locked away in obscure publications and isolated from one another. Methods of data collection were to gather body mass data 1) from the Paleobiology Database's North American Fossil Mammal Systematics Database (NAFMSD) and publications (e.g. see MacFadden and Hulbert, 1990 and Christiansen, 2004), or 2) calculate estimates of mass from tooth measurements on a specific taxon from the NAFMSD, Janis et al. (1998), or Janis et al. (2008) using regression or allometric equations (Table A.1) for the lowest possible 
classification (class, order, family) from publications such as Legendre (1986), Legendre and Roth (1988), Damuth (1990), Janis (1990), Alroy (1998b, 1999), Bloch et al. (1998), or 3) average the mass from a range of data on a taxon's genus from the NAFMSD or Silva and Downing (1995) on genera at masses above $18 \mathrm{~g}$ (Smith et al., 2004). The third method was rarely required and species belonging to genera less than $18 \mathrm{~g}$ requiring this step were not encountered. Actual data are presented in Table A.3.

Table A.1. Prediction equations for mammalian body mass (g) from lower first molar tooth (mm) measurements.

\begin{tabular}{|c|c|c|}
\hline Group & Prediction Equation & Reference \\
\hline All Mammals & $\ln \left(B_{M}\right)=1.827^{*} \ln \left(m_{1}\right.$ area $)+1.81$ & Legendre, 1986 \\
\hline Carnivora & $\ln \left(B_{M}\right)=1.897^{*} \ln \left(m_{1}\right.$ area $)+1.653$ & Legendre and Roth, 1988 \\
\hline Canidae & $\ln \left(B_{M}\right)=2.815^{*} \ln \left(m_{1}\right.$ area $)+1.337$ & Legendre and Roth, 1988 \\
\hline Felidae & $\ln \left(B_{M}\right)=2.951 * \ln \left(m_{1}\right.$ area $)+1.535$ & Legendre and Roth, 1988 \\
\hline Ursidae & $\ln \left(B_{M}\right)=2.033^{*} \ln \left(m_{1}\right.$ area $)+1.886$ & Legendre and Roth, 1988 \\
\hline Mustelidae & $\ln \left(B_{M}\right)=1.374 * \ln \left(m_{1}\right.$ area $)+1.649$ & Legendre and Roth, 1988 \\
\hline Non-selenodont Ungulates & $\log \left(B_{M}\right)=3.12 * \log \left(p_{4}-m_{2}\right.$ length $)-0.43$ & Damuth, 1990 \\
\hline All Ungulates & $\ln \left(B_{M}\right)=3.263 * \ln \left(m_{1}\right.$ area $)+1.337$ & Janis, 1990 \\
\hline Perissodactyla & $\ln \left(B_{M}\right)=3.187^{*} \ln \left(m_{1}\right.$ area $)+1.264$ & Janis, 1990 \\
\hline Rodentia & $\ln \left(B_{M}\right)=1.767 * \ln \left(m_{1}\right.$ area $)+3.267$ & Legendre, 1986 \\
\hline Lipotyphla & $\ln \left(B_{M}\right)=1.714 * \ln \left(m_{1}\right.$ area $)+0.886$ & Bloch et al., 1998 \\
\hline Primates & $\ln \left(B_{M}\right)=1.49 * \ln \left(m_{1}\right.$ area $)+3.577$ & Legendre, 1986 \\
\hline
\end{tabular}


Collecting data on species and their temporal ranges was done with the NAFMSD, Carrasco et al. (2005; “MIOMAP”), Janis et al. (1998), or Janis et al. (2008). However, corrections were made on temporal ranges of taxa from literature using the temporal ranges of formations (Table AI.2). Rather than use the North American Land Mammal Ages (NALMA) of Tedford et al. (2004) or the revised quantitative NALMA time scale of Alroy (2003), temporal ranges of formations and outcrops are used instead since many of the temporo-stratigraphic benchmarks, tie points, and stratigraphic applications (i.e. dated tuffs and paleomagnetism) used by these authors are not up to date (e.g. re: RST and DvCT). The unfortunate part of this is that the temporal resolution of species ranges has the potential to decrease dramatically since a species may actually become regionally extinct below the upper-most dated horizon of a formation or may first occur somewhere above. For example, this is true in my experience regarding less common taxa in outcrops of the John Day Formation. Hence, one could argue that since the resolution of the data is so low that the pattern cannot be completely understood and therefore, the test of the pattern does not fulfill its promise. However, viewing the data at the outcrop scale is a more precise endeavor than applying ranges to species based on a qualitative or quantitative NALMA since the focus is on more restricted areas and temporal data are up to date. Moreover, nearly all the fossiliferous formations in the LMPN are much shorter in duration than the John Day Formation (a Miocene average of approximately a little less than four million years/formation or basin $(n=17)$ compared to the approximate 20 million years of the John Day Formation). Therefore, in this case, NALMA's are far lower in their resolution despite their advantages of correlation across greater spatial scales. 
Table A.2. Formations and their temporal durations as determined by their references.

\begin{tabular}{|c|c|c|}
\hline Formation & Age Range & Reference \\
\hline Deschutes Fm. & $7.6-4 \mathrm{Ma}$ & Smith, 1986 \\
\hline Chenoweth Fm. & $7.5-5.1 \mathrm{Ma}$ & Farooqui et al., 1981 \\
\hline Tygh Valley Fm. & $7.4-4.9 \mathrm{Ma}$ & Farooqui et al., 1981 \\
\hline Alkali Canyon Fm. & $<10.5 \mathrm{Ma}$ & Farooqui et al., 1981 \\
\hline McKay Fm. & < $14 \mathrm{Ma} ; 10$ - 4.5 Ma & $\begin{array}{l}\text { Bergerren and van Couvering, 1974; } \\
\text { Farooqui et al., } 1981\end{array}$ \\
\hline John Day Fm. & 39.72 - 20 Ma & $\begin{array}{l}\text { Retallack et al., } 1996 \\
\text { Fremd et al, } 1994\end{array}$ \\
\hline Clarno Fm. & $53.5-43.4 \mathrm{Ma}$ & Bestland et al., 1999 \\
\hline Ellensberg Fm. & $17-\sim 5 \mathrm{Ma}$ & Smith, 1988 \\
\hline Ringold Fm. & $8.5-3.4 \mathrm{Ma}$ & Fecht et al., 1987 \\
\hline Mascall Fm. & $\sim 16-14.8 \mathrm{Ma}$ & Prothero et al., 2006a; \\
\hline Rattlesnake Fm. & $7.5-6.9 \mathrm{Ma}$ & $\begin{array}{l}\text { Retallack et al., 2002; } \\
\text { Retallack, writ comm, 2008; } \\
\text { Prothero et al., 2006b }\end{array}$ \\
\hline Drewsey Fm. & $9.68-6.9 \mathrm{Ma}$ & $\begin{array}{l}\text { Johnson et al., 1996; } \\
\text { Retallack 2004; } \\
\text { Camp et al. } 2003\end{array}$ \\
\hline Juntura Fm. & 10.9 - 9.68 Ma & Kohn and Law, 2006 \\
\hline Ironside Fm. & $12.4-9.68 \mathrm{Ma}$ & $\begin{array}{l}\text { Everenden and James, 1964*; } \\
\text { Johnson et al., 1996; } \\
\text { Retallack, } 2004\end{array}$ \\
\hline Deer Butte Fm. & $15-12.6 \mathrm{Ma}$ & Cummings, 1991 \\
\hline $\begin{array}{l}\text { Butte Creek } \\
\text { Volcanic Sandstone } \\
\text { Fm. }\end{array}$ & 15.8 - 15.5 Ma? & $\begin{array}{l}\text { Everenden and James, 1964*; } \\
\text { Evans, 1990; } \\
\text { Swisher, } 1992\end{array}$ \\
\hline Sucker Creek Fm. & $>15.46-<14.77 \mathrm{Ma}$ & $\begin{array}{l}\text { Downing 1992; } \\
\text { Downing and Swisher 1993; }\end{array}$ \\
\hline
\end{tabular}


Table A.2. continued

\begin{tabular}{|c|c|c|}
\hline Chalk Butte Fm. & $<10.18 \mathrm{Ma}-\sim 3 \mathrm{Ma}$ & $\begin{array}{l}\text { Hart, 1982*; } \\
\text { Cummings et al., 2000; } \\
\text { Kimmel, } 1982 \text { (and references therein) }\end{array}$ \\
\hline Chalk Hills Fm. & $8.9-6.6 \mathrm{Ma}$ & $\begin{array}{l}\text { Kimmel, 1982; } \\
\text { Beranek et al., } 2006\end{array}$ \\
\hline Glens Ferry Fm. & $5-3 \mathrm{Ma}$ & Beranek et al., 2006 \\
\hline Starlight Fm. & $\sim>10.2-\sim>6.2 \mathrm{Ma}$ & Kellogg et al., 1994 \\
\hline Humboldt Fm. & $15.54-9.81 \mathrm{Ma}$ & Perkins et al., 1998 \\
\hline Virgin Valley Fm. & $>16.28-<15.18 \mathrm{Ma}$ & Perkins et al., 1998 \\
\hline Thousand Creek Fm. & $8.3-7.02 \mathrm{Ma}$ & $\begin{array}{l}\text { Perkins et al., 1998; } \\
\text { Prothero and Davis, } 2008\end{array}$ \\
\hline Lake Idaho & $9.5-2.5 \mathrm{Ma}$ & Beranek et al., 2006 \\
\hline Harney Basin & $9.68-7.05 \mathrm{Ma}$ & Sheppard, 1995 [modified] \\
\hline
\end{tabular}

* Corrected using Dalrymple (1979)

State of the mammalian fossil record: small mammals vs. large mammals

A number of biases can affect the study of fossil organisms. For fossil mammals these include: collecting biases for size or taxonomic group (Lyman, 1984; Retallack, 1988; Behrensmeyer et al., 2000) due to visibility or preservation biases, naming biases for size or taxonomic group (Alroy, 2003) due to worker preferences or competitive inclination (e.g. O.C. Marsh and E.D. Cope's late $19^{\text {th }}$ century naming feud), debate biases for taxonomic nomenclature (Alroy, 2003) due to synonymous or dubious names, and preservation biases for size (Behrensmeyer et al., 1979; Behrensmeyer, 1988; 
Retallack, 1988; Foote and Raup, 1996; see also Sections 2.1.1 and 2.1.2 in main body of text for further explanations) due to physical and chemical destruction of organic remains, the negative correlation of abundance with size, or the positive correlation of abundance with preservation.

With all these biases it is difficult to know what to account for when regarding numbers of taxa in different categories such as size or taxonomic group. Section 2.1.1 expands on this topic regarding inherent qualities in taxa that influence their presence in the fossil record. Section 2.1.3 illustrates what the pattern or size distributions may indicate. Additionally, below is a short summary of the potential role climate has on diversity as filtered through the fossil record and different size groups.

Recent studies on the consequences of climate on mammalian diversity and turnover through time have generated opposing observations and they have led to different interpretations of climate effects on evolution in mammals. This, in turn, perhaps influences diversity biases which will affect species abundance, geographic extent, and lifespan (see Section 2.1.1). Results for one study (van Dam et al., 2006) explains small mammal species life spans are determined by orbital eccentricity cycle minima (2.37 Ma) and obliquity cycle nodes (1.2 Ma) which correspond to mean mammalian life spans (2.5 Ma; Alroy, 2000). Hence, at these orbital cycles small mammal diversity turns over - at least in the Neogene (24-2 Ma) fluvio-lacustrine sections in the Madrid, Calatayud-Daroca and Teruel basins from central Spain. Meanwhile, results of another study (Liow et al., 2008) using the Neogene Old World (NOW) fossil mammal database have indicated that large mammals turnover more rapidly than small mammals. The authors of this report cite multiple reasons for this 
pattern in large mammals. Examples include more frequent deleterious mutations, smaller population sizes, longer generation times, and a low frequency in sleep-or-hide behavior (SLOH; e.g., hibernation, torpor, and burrowing). Despite these research efforts, Barry et al. (2002) could only find partial qualitative evidence for turnover events in large mammals related to environmental (e.g., fluvial and vegetation) or climate change in the Siwalik formations of the Potwar Plateau of northern Pakistan. Finding partial qualitative evidence for turnover is diminished somewhat by the efforts of the more quantitative studies put forth recently (as mentioned above) and most likely in the near future. Furthermore, a quantitative study (Alroy et al., 2000) indicated no correlation between (mostly western) North American mammal diversity changes and Atlantic benthic foraminiferal oxygen isotope ratios over the same time period. However, one could argue these records are at the opposite ends of any potential number of energy and mass transfer pathways within Earth's global surficial system. How is one to know when, where, or how along the way from global temperature-proxied by oxygen isotopes - to ecosystem diversity dynamics, the initial temperature signal was strong, lost, or scattered before it reached ecological communities and their accompanying populations? Alroy et al. (2000) briefly touched on a similar impression while mostly making their argument against a direct correlation between global temperature and western North American mammalian diversity and turnover. 
Table A.3. Cenozoic PNW mammalian mass, first occurance (FO), and last occurance (LO) data mined from collections in an $\sim 500,000 \mathrm{~km}^{2}$ area centered on Harney Basin, Oregon. Data sorted oldest to youngest by LO.

\begin{tabular}{|c|c|c|c|c|}
\hline Taxon & mass (g) & $\mathrm{FO}(\mathrm{Ma})$ & $\mathrm{LO}(\mathrm{Ma})$ & notes/comments \\
\hline Hyrachyus eximius & 87400 & 44.10 & 43.70 & \\
\hline Patriofelis ferox & 22418 & 44.10 & 43.70 & mass from P. ultra \\
\hline Telmatherium sp. & 420250 & 44.10 & 43.70 & mass from mean of known estimates in genus \\
\hline Xenicohippus craspedotus & 10895 & 44.10 & 43.70 & mass from mean of known estimates in genus \\
\hline Achaenodon fremdi & 774100 & 43.70 & 39.70 & mass from $A$. robustrus \\
\hline Epihippus gracilis & 7800 & 43.70 & 39.70 & \\
\hline Haplohippus texanus & 13800 & 43.70 & 39.70 & \\
\hline Hemipsalodon grandis & & 43.70 & 39.70 & \\
\hline Heptacodon sp. & 127600 & 43.70 & 39.70 & \\
\hline Plesiocolopirus hancocki & 23700 & 43.70 & 39.70 & \\
\hline Procadurcodon sp. & & 43.70 & 39.70 & \\
\hline Protitanops curryi & 1424775 & 43.70 & 39.70 & $\begin{array}{l}\text { mass guesstimated as } 3 / 4 \text { the mass of Brontops based on comparisons of } \\
M 2 \text { lengths. }\end{array}$ \\
\hline Teletaceras radinskyi & 91600 & 43.70 & 39.70 & \\
\hline Colodon sp. & 49980 & 39.70 & 37.50 & mass from mean of known estimates in genus \\
\hline Mesohippus bairdi & 22000 & 32.90 & 32.60 & \\
\hline Subhyracodon sp. & 159900 & 32.90 & 32.60 & mass from mean of known estimates in genus \\
\hline Diceratherium sp. & 515780 & 30.28 & 30.00 & mass from mean of known estimates in genus \\
\hline Agriochoerus sp. & 63850 & 43.70 & 29.73 & mass from mean of known estimates in genus \\
\hline Archaeocyon pavidus & 902 & 30.00 & 29.73 & \\
\hline Enhydrocyon sp. & 24280 & 30.00 & 29.73 & mass from mean of known estimates in genus \\
\hline Eusmilus cerebralis & & 30.00 & 29.73 & \\
\hline Perchoerus sp. & 60733 & 30.00 & 29.73 & mass from mean of known estimates in genus \\
\hline Temnocyon altigenis & 19300 & 30.00 & 29.73 & \\
\hline Thinohyus lentus & 101400 & 30.00 & 29.73 & \\
\hline Allocyon loganensis & & 30.00 & 28.90 & \\
\hline Archaeolagus ennisianus & 198 & 29.45 & 28.70 & \\
\hline Cynarctoides lemur & 1020 & 30.00 & 28.70 & \\
\hline
\end{tabular}


Table A.3 continued.

\begin{tabular}{|c|c|c|c|c|}
\hline Dinaelurus crassus & 37320 & 29.45 & 28.70 & \\
\hline Dinictis cyclops & & 29.45 & 28.70 & \\
\hline Enhydrocyon stenocephalus & 22100 & 29.45 & 28.70 & \\
\hline Haplomys liolophus & 39 & 30.00 & 28.70 & mass from $H$. galbreathi \\
\hline Leptocyon mollis & 3300 & 29.45 & 28.70 & mass from mean of known estimates in genus \\
\hline Merycoidodon bullatus & 109500 & 29.45 & 28.70 & \\
\hline Mesocyon coryphaeus & 10400 & 29.45 & 28.70 & \\
\hline Mesocyon sp. & 7618 & 29.45 & 28.70 & mass from mean of known estimates in genus \\
\hline Micropternodus morgani & 72 & 29.45 & 28.70 & \\
\hline Miohippus anceps & 41650 & 29.45 & 28.70 & mass from mean of known estimates in genus \\
\hline Miohippus condoni & 41650 & 29.45 & 28.70 & mass from mean of known estimates in genus \\
\hline Miohippus equiceps & 41650 & 29.45 & 28.70 & mass from mean of known estimates in genus \\
\hline Miosciurus ballovianus & 37 & 29.45 & 28.70 & \\
\hline Osbornodon sesnoni & 7430 & 29.45 & 28.70 & \\
\hline Palaeocastor peninsulatus & 947 & 29.45 & 28.70 & mass from mean of known estimates in genus \\
\hline Phlaocyon latidens & 1580 & 30.00 & 28.70 & \\
\hline Pogonodon platycopis & 31200 & 29.45 & 28.70 & mass from $P$. eileenae \\
\hline Allomys simplicidens & 122 & 28.70 & 27.50 & mass from mean of known estimates in genus \\
\hline Alwoodia magna & 226 & 28.70 & 27.50 & mass from $A$. harkseni $\mathrm{m} 1$ area \\
\hline Capacikala gradatus & & 28.70 & 27.50 & \\
\hline Desmatochoerus megalodon & 335100 & 28.70 & 27.50 & \\
\hline Diceratherium armatum & 1250100 & 32.90 & 27.50 & \\
\hline Hypertragulus hesperius & 4572 & 30.00 & 27.50 & \\
\hline Jimomys lulli & 28 & 28.70 & 27.50 & \\
\hline Meniscomys uhtoffi & 70 & 28.70 & 27.50 & mass from $M$. hippodus \\
\hline Mesoreodon minor & 159700 & 28.70 & 27.50 & \\
\hline Miohippus intermedius & 43000 & 28.70 & 27.50 & \\
\hline Nimravus brachyops & 52604 & 30.00 & 27.50 & \\
\hline Pleurolicus sulcifrons & 84 & 28.70 & 27.50 & \\
\hline
\end{tabular}


Table A.3 continued.

\begin{tabular}{|c|c|c|c|c|}
\hline Allomys sp. & 122 & 27.50 & 25.30 & mass from mean of known estimates in genus \\
\hline Cormocyon copei & 3210 & 29.45 & 25.30 & \\
\hline Daphoenus sp. & 7919 & 30.00 & 25.30 & mass from mean of known estimates in genus \\
\hline Diceratherium annectens & 227800 & 30.00 & 25.30 & mass estimated from $\mathrm{M} 3$ length \\
\hline Ekgmowechashala sp. & 1085 & 27.50 & 25.30 & \\
\hline Entoptychus basilaris & 84 & 27.50 & 25.30 & mass from mean of known estimates in genus \\
\hline Eporeodon occidentalis & 118300 & 30.00 & 25.30 & \\
\hline Gentilicamelus sternbergi & 77400 & 27.50 & 25.30 & \\
\hline Merycoidodon major & 62200 & 28.70 & 25.30 & \\
\hline Mesocyon brachyops & 7040 & 29.45 & 25.30 & \\
\hline Miohippus sp. & 41650 & 30.28 & 25.30 & mass from mean of known estimates in genus \\
\hline Oreodontoides oregonensis & 34900 & 28.70 & 25.30 & \\
\hline Oreodontoides sp. & 34900 & 28.70 & 25.30 & mass from $O$. oregonensis \\
\hline Paraenhydrocyon josephi & 6670 & 30.00 & 25.30 & \\
\hline Pogonodon n. sp. & 15600 & 27.50 & 25.30 & $\begin{array}{l}\text { apparent dwarfed new Pogonodon species guesstimated here at half } P \text {. } \\
\text { eileenae's mass }\end{array}$ \\
\hline Protospermophilus vortmani & 230 & 28.70 & 25.30 & \\
\hline Agriochoerus guyotianus & 59000 & 32.90 & 23.80 & \\
\hline Archaeotherium sp. & 2109817 & 32.90 & 23.80 & mass from mean of known estimates in genus \\
\hline Entoptychus cavifrons & 70 & 25.30 & 23.80 & \\
\hline Entoptychus minor & 84 & 25.30 & 23.80 & mass from mean of known estimates in genus \\
\hline Entoptychus productidens & 84 & 25.30 & 23.80 & mass from mean of known estimates in genus \\
\hline Entoptychus transitorius & 84 & 25.30 & 23.80 & mass from mean of known estimates in genus \\
\hline Entoptychus wheelerensis & 84 & 27.50 & 23.80 & mass from mean of known estimates in genus \\
\hline Hypertragulus calcaratus & 8880 & 27.50 & 23.80 & \\
\hline Kalobatippus praestans & & 25.30 & 23.80 & \\
\hline Leidymys nematodon & 38 & 25.30 & 23.80 & mass from mean of known estimates in genus \\
\hline Meniscomys hippodus & 70 & 27.50 & 23.80 & \\
\hline Merycochoerus superbus & 438400 & 27.50 & 23.80 & \\
\hline
\end{tabular}


Table A. 3 continued.

\begin{tabular}{|c|c|c|c|c|}
\hline Merycoides pariogonus & 77000 & 27.50 & 23.80 & \\
\hline Micropternodus sp. & 71 & 25.30 & 23.80 & mass from mean of known estimates in genus \\
\hline Miohippus primus & 41650 & 25.30 & 23.80 & mass from mean of known estimates in genus \\
\hline Nanotragulus planiceps & 3678 & 29.45 & 23.80 & mass from mean of known estimates in genus \\
\hline Oligobunis crassivultus & 13000 & 25.30 & 23.80 & mass from $O$. floridanus \\
\hline Palaeolagus sp. & 161 & 27.50 & 23.80 & mass from mean of known estimates in genus \\
\hline Palustrimus lewisi & 84 & 25.30 & 23.80 & mass from mean of known estimates in genus; i.e. Entoptychus \\
\hline Paroreodon parvus & 51150 & 27.50 & 23.80 & \\
\hline Proheteromys thorpei & 16 & 25.30 & 23.80 & \\
\hline Protosciurus condoni & 629 & 25.30 & 23.80 & \\
\hline Rhizocyon oregonensis & 1570 & 30.00 & 23.80 & \\
\hline Schizodontomys sulcidens & 65 & 25.30 & 23.80 & \\
\hline Daphoenodon sp. & 45000 & 25.30 & 23.20 & mass from mean of known estimates in genus \\
\hline Daphoenus socialis & 13000 & 25.30 & 23.20 & \\
\hline Entoptychus planifrons & 135 & 25.30 & 23.20 & \\
\hline Hypsiops breviceps & 230500 & 29.45 & 23.20 & \\
\hline Merycochoerus matthewi & 448333 & 23.80 & 23.20 & mass from mean of known estimates in genus \\
\hline Merycoides longiceps & 108633 & 23.80 & 23.20 & \\
\hline Paradaphoenus sp. & 2040 & 23.80 & 23.20 & mass from mean of known estimates in genus \\
\hline Rudiomys mcgrewi & & 23.80 & 23.20 & \\
\hline Schizodontomys greeni & 94 & 23.80 & 23.20 & mass from mean of known estimates in genus \\
\hline Merycochoerus sp. & 448333 & 22.00 & 19.60 & mass from mean of known estimates in genus \\
\hline Miotapirus sp. & 71400 & 23.20 & 19.60 & mass from $M$. harrisonensis \\
\hline Moropus oregonensis & 90300 & 25.30 & 19.60 & \\
\hline Archaeohippus sp. & 26571 & 22.00 & 19.00 & mass from mean of known estimates in genus \\
\hline Archaeolagus macrocephalus & 374 & 23.80 & 19.00 & \\
\hline Entoptychus individens & 84 & 25.30 & 19.00 & mass from mean of known estimates in genus \\
\hline Hypertragulus sp. & 10423 & 30.28 & 19.00 & mass from mean of known estimates in genus \\
\hline Merychyus arenarum & 75000 & 23.80 & 19.00 & \\
\hline
\end{tabular}


Table A.3 continued.

\begin{tabular}{|c|c|c|c|c|}
\hline Merychyus minimus & 41200 & 22.00 & 19.00 & \\
\hline Nexuotapirus robustus & 138200 & 25.30 & 19.00 & \\
\hline Palaeocastor sp.? & 947 & 22.00 & 19.00 & mass from mean of known estimates in genus \\
\hline Parahippus leonensis & 48700 & 22.00 & 19.00 & \\
\hline Alphagaulus vetus & 521 & 16.58 & 16.47 & \\
\hline Ansomys nevadensis & 52 & 16.58 & 16.47 & \\
\hline Bassaricyonoides stewartae & 1700 & 16.58 & 16.47 & mass fom $B$. phyllismillerae $\mathrm{m} 1$ area \\
\hline Bouromeryx submilleri & 69100 & 22.00 & 16.47 & \\
\hline Cynorca sociale & 39800 & 22.00 & 16.47 & \\
\hline Hesperhys pinensis & 246700 & 16.58 & 16.47 & \\
\hline Hesperhys vagrans & 181000 & 16.58 & 16.47 & \\
\hline Limnoecus compressus & & 16.58 & 16.47 & \\
\hline Liodontia sp. & 198 & 16.58 & 16.47 & mass from L. alexandrae \\
\hline Megapeomys bobwilsoni & 413 & 16.58 & 16.47 & \\
\hline Miospermophilus sp. & 84 & 16.58 & 16.47 & \\
\hline Miospermophilus wyomingensis & 83 & 16.58 & 16.47 & \\
\hline Paracosoryx wilsoni & & 16.58 & 16.47 & \\
\hline Parapliohippus carrizoensis & 42300 & 16.58 & 16.47 & \\
\hline Protospermophilus angusticeps & 321 & 16.58 & 16.47 & \\
\hline Protospermophilus sp. & 218 & 16.58 & 16.47 & mass from mean of known estimates in genus \\
\hline Subdromomeryx antilopinus & & 16.58 & 16.47 & \\
\hline Ursavus brevirhinus & & 16.58 & 16.47 & \\
\hline Amphicyon frendens & 135600 & 15.80 & 15.50 & \\
\hline Bouromeryx americanus & 92200 & 16.58 & 15.50 & \\
\hline Cynelos sinapius & 133000 & 15.80 & 15.50 & \\
\hline Euoplocyon brachygnathus & 9380 & 15.80 & 15.50 & \\
\hline Hesperogaulus gazini & & 15.80 & 15.50 & \\
\hline Lanthanotherium sp. & 91 & 15.80 & 15.50 & mass from L. sawini \\
\hline
\end{tabular}


Table A.3 continued.

\begin{tabular}{|c|c|c|c|c|}
\hline Limnoecus sp. & 5 & 15.80 & 15.50 & $\begin{array}{l}\text { some taxa in genus have mass below } 18 \mathrm{~g} \text {; however, there are real } \mathrm{m} 1 \text { length } \\
\text { and width measurements for "L. sp." }\end{array}$ \\
\hline Martes gazini & 1767 & 15.80 & 15.50 & mass from mean of known estimates in genus \\
\hline Monosaulax typicus & 367 & 15.80 & 15.50 & \\
\hline Oreolagus wallacei & 77 & 15.80 & 15.50 & \\
\hline Paradomnina relictus & 24 & 15.80 & 15.50 & \\
\hline Parahippus pawniensis & 51100 & 16.58 & 15.50 & \\
\hline Paratomarctus temerarius & 11100 & 15.80 & 15.50 & \\
\hline Petauristodon sp. & & 15.80 & 15.50 & \\
\hline Pliocyon medius & 105700 & 15.80 & 15.50 & \\
\hline Protospermophilus malheurensis & 103 & 15.80 & 15.50 & \\
\hline Pseudotrimylus mawbyi & 142 & 15.80 & 15.50 & \\
\hline Pseudotrimylus sp. & 142 & 16.58 & 15.50 & mass from $P$. mawbyi \\
\hline Scapanoscapter simplicidens & 59 & 15.80 & 15.50 & \\
\hline Ticholeptus sp.? & 154900 & 15.80 & 15.50 & mass from $T$. zygomaticus \\
\hline Ursavus primaevus & & 15.80 & 15.50 & \\
\hline Alphagaulus pristinus & 521 & 15.85 & 15.18 & mass from $A$. vetus $\mathrm{m} 1$ area \\
\hline Blastomeryx mollis & 35700 & 15.85 & 15.18 & mass from mean of known estimates in genus \\
\hline Hesperhys sp. & 213850 & 15.85 & 15.18 & mass from mean of known estimates in genus \\
\hline Hypolagus parviplicatus & 323 & 15.85 & 15.18 & \\
\hline Liodontia alexandrae & 198 & 15.85 & 15.18 & \\
\hline Metatomarctus sp. A & 10500 & 15.85 & 15.18 & mass from $M$. canavus \\
\hline Monosaulax skinneri & 830 & 15.85 & 15.18 & \\
\hline Oreolagus nevadensis & 78 & 15.85 & 15.18 & mass from mean of known estimates in genus \\
\hline Paracosoryx sp. & & 15.85 & 15.18 & \\
\hline Paracynarctus kelloggi & 8160 & 16.58 & 15.18 & \\
\hline Peraceras profectum & 435250 & 15.85 & 15.18 & $\begin{array}{l}\text { mass from mean of two separate estimates on } \mathrm{M} 2 \text { area and } \mathrm{M} 3 \text { length, } \\
\text { respectively. Certainty of value unknown. }\end{array}$ \\
\hline Probassariscus antiquus (mathewi?) & 916 & 15.85 & 15.18 & \\
\hline
\end{tabular}


Table A. 3 continued.

\begin{tabular}{|c|c|c|c|c|}
\hline Protomarctus optatus & 11100 & 16.58 & 15.18 & \\
\hline Thinohyus sp. & 101400 & 15.85 & 15.18 & mass from $T$. lentus \\
\hline Zygolophodon proavus & & 15.85 & 15.18 & \\
\hline Archaeohippus ultimus & 26571 & 15.80 & 14.80 & mass from mean of known estimates in genus \\
\hline Arctomyoides sp. & 1230 & 15.77 & 14.80 & mass from $A$. arctomyoides $\mathrm{m} 1$ area \\
\hline Cynorca sp. & 44425 & 15.77 & 14.80 & mass from mean of known estimates in genus \\
\hline Hypolagus sp. & 319 & 15.77 & 14.80 & mass from mean of known estimates in genus \\
\hline Leptarctus oregonensis & 2580 & 15.77 & 14.80 & mass from L. primus \\
\hline Protospermophilus oregonensis & 218 & 15.77 & 14.80 & mass from mean of known estimates in genus \\
\hline Tephrocyon rurestris & 12100 & 15.80 & 14.80 & \\
\hline Acritohippus isonensis & 67000 & 15.85 & 14.77 & \\
\hline Hypohippus osborni & 137100 & 15.85 & 14.77 & \\
\hline Moropus sp. & 173767 & 16.58 & 14.77 & mass from mean of known estimates in genus \\
\hline Pseudotheridomys sp. & 8 & 15.46 & 14.77 & mass from $P$. pagei \\
\hline Ursavus sp. & & 30.00 & 14.77 & \\
\hline Brachycrus sp. & 328700 & 16.12 & 14.50 & \\
\hline Desmatippus avus & 86700 & 15.85 & 14.50 & \\
\hline Hypohippus sp. & 117775 & 16.12 & 14.50 & mass from mean of known estimates in genus \\
\hline Merychippus brevidontus & 62200 & 16.12 & 14.50 & \\
\hline Merychippus californicus & 44700 & 16.12 & 14.50 & \\
\hline Merychippus close & 60471 & 16.12 & 14.50 & mass from mean of known estimates in genus \\
\hline Metatomarctus sp. & 10500 & 16.12 & 14.50 & mass from $M$. canavus \\
\hline Moropus merriami & 173767 & 16.12 & 14.50 & mass from mean of known estimates in genus \\
\hline Paracosoryx nevadensis & & 16.12 & 14.50 & \\
\hline Ticholeptus zygomaticus & 154900 & 16.58 & 14.50 & \\
\hline Ursavus pawniensis & & 16.12 & 14.50 & \\
\hline Zygolophodon sp. & & 16.58 & 14.50 & \\
\hline Achlyoscapter longirostris & 12 & 15.80 & 12.60 & \\
\hline Alluvisorex arcadentes & 6 & 15.80 & 12.60 & \\
\hline
\end{tabular}


Table A. 3 continued.

\begin{tabular}{|c|c|c|c|c|}
\hline Copemys barstowensis & 27 & 15.00 & 12.60 & \\
\hline Copemys pagei & 12 & 15.80 & 12.60 & \\
\hline Domninoides sp. & 83 & 15.00 & 12.60 & mass from mean of known estimates in genus \\
\hline Dromomeryx borealis & 278700 & 15.85 & 12.60 & \\
\hline Ingentisorex tumididens & 89 & 15.00 & 12.60 & \\
\hline Leptodontomys quartzi & 3 & 15.00 & 12.60 & \\
\hline Macrognathomys sp. & 5 & 15.00 & 12.60 & \\
\hline Merychippus relictus & 60471 & 15.77 & 12.60 & mass from mean of known estimates in genus \\
\hline Monosaulax progressus & 427 & 15.00 & 12.60 & \\
\hline Mustela sp. & 505 & 15.00 & 12.60 & mass from mean of known estimates in genus \\
\hline Mystipterus pacificus & 15 & 15.80 & 12.60 & \\
\hline Peridiomys oregonensis & 28 & 15.80 & 12.60 & \\
\hline Plesiosorex donroosai & 686 & 15.80 & 12.60 & \\
\hline Pseudotheridomys pagei & 8 & 15.80 & 12.60 & \\
\hline Scalopoides ripafodiator & 28 & 15.80 & 12.60 & \\
\hline Spermophilus tephrus & 89 & 15.80 & 12.60 & \\
\hline Hoplictis grangerensis & 15700 & 12.00 & 10.50 & \\
\hline Ammospermophilus junturensis & 54 & 10.57 & 9.68 & \\
\hline Copemys dentalis & 13 & 10.57 & 9.68 & \\
\hline Crusafontina minima & 14 & 10.57 & 9.68 & \\
\hline Cupidinimus sp. & 11 & 10.57 & 9.68 & $\begin{array}{l}\text { some taxa in genus have mass below } 18 \mathrm{~g} \text {; however, there are real } \mathrm{m} 1 \\
\text { length and width measurements for " } C . s p . "\end{array}$ \\
\hline Eucastor malheurensis & 746 & 10.57 & 9.68 & \\
\hline Gomphotherium sp.? & 4157231 & 10.57 & 9.68 & mass from mean of estimates of G. productens (Christiansen, 2004) \\
\hline Hesperolagomys galbreathi & 136 & 10.57 & 9.68 & \\
\hline Hesperosorex sp.? & & 10.57 & 9.68 & \\
\hline Hypolagus fontinalis & 228 & 15.77 & 9.68 & \\
\hline Hystricops sp.? & 2500 & 10.57 & 9.68 & mass from $H$. venustus \\
\hline Leptocyon sp. & 3300 & 10.57 & 9.68 & mass from mean of known estimates in genus \\
\hline
\end{tabular}


Table A.3 continued.

\begin{tabular}{|c|c|c|c|c|}
\hline Mammut furlongi & 6310400 & 10.57 & 9.68 & mass from mean of estimates of M. americanum (Christiansen, 2004) \\
\hline Megatylopus sp. & 1665000 & 10.57 & 9.68 & mass from mean of known estimates in genus \\
\hline Merychyus sp. & 100686 & 16.58 & 9.68 & mass from mean of known estimates in genus \\
\hline Mystipterus sp. & 15 & 10.57 & 9.68 & $\begin{array}{l}\text { some taxa in genus have mass below } 18 \mathrm{~g} \text {; however, there are real } \mathrm{m} 1 \\
\text { length and width measurements for "M. } s p . "\end{array}$ \\
\hline Plesiosorex sp. & 340 & 10.57 & 9.68 & mass from mean of known estimates in genus \\
\hline Procamelus grandis & 606800 & 10.57 & 9.68 & \\
\hline Scapanus shultzi & 97 & 10.57 & 9.68 & mass from mean of known estimates in genus \\
\hline Sthenictis junturensis & 4740 & 10.57 & 9.68 & \\
\hline Tardontia occidentale & 186 & 10.57 & 9.68 & \\
\hline Sthenictis sp. & 5810 & 10.57 & 8.90 & mass from mean of known estimates in genus \\
\hline Borophagus pugnator & 36100 & 8.90 & 8.50 & tf is questionable \\
\hline Pliosaccomys sp. & 22 & 10.57 & 7.83 & mass from mean of known estimates in genus \\
\hline Aphelops sp. & 1170050 & 16.58 & 7.02 & mass from mean of known estimates in genus \\
\hline Dinohippus sp. & 262840 & 8.30 & 7.02 & mass from mean of known estimates in genus \\
\hline Diprionomys minnimus & 21 & 8.30 & 7.02 & \\
\hline Dromomeryx sp. & 278700 & 15.77 & 7.02 & mass from $D$. borealis, the only known and validated species in this genus \\
\hline Hesperogaulus sp. & & 15.85 & 7.02 & \\
\hline Hipparion sp. & 69300 & 8.30 & 7.02 & mass from mean of known estimates in genus \\
\hline Ilingoceros alexandrae & & 8.30 & 7.02 & \\
\hline Ilingoceros schizoceros & & 8.30 & 7.02 & \\
\hline Mammut matthewi & 6310400 & 8.30 & 7.02 & mass from mean of estimates of $M$. americanum (Christiansen, 2004) \\
\hline Marmota minor & 1204 & 8.30 & 7.02 & \\
\hline Paenemarmota nevadensis & 7644 & 8.30 & 7.02 & \\
\hline Pliogale furlongi & 946 & 8.30 & 7.02 & \\
\hline Prosthennops sp. & 135875 & 8.30 & 7.02 & mass from mean of known estimates in genus \\
\hline Protohippus sp. & 66900 & 8.30 & 7.02 & mass from mean of known estimates in genus \\
\hline Pseaudaelurus sp. A & 22320 & 8.30 & 7.02 & mass from mean of known estimates in genus \\
\hline Pseaudaelurus sp. B & 22320 & 8.30 & 7.02 & mass from mean of known estimates in genus \\
\hline
\end{tabular}


Table A. 3 continued.

\begin{tabular}{|c|c|c|c|c|}
\hline Spermophilus argonautus & 131 & 8.30 & 7.02 & \\
\hline Sphenophalos nevadanus & & 8.30 & 7.02 & \\
\hline Dipoides vallicula & 850 & 7.50 & 7.00 & \\
\hline Peromyscus pliocenicus & 13 & 7.50 & 7.00 & \\
\hline Plionictis oregonensis & 1030 & 7.50 & 7.00 & \\
\hline Pseudaelurus sp. & 22320 & 15.80 & 7.00 & mass from mean of known estimates in genus \\
\hline Spermophilus sp. & 204 & 10.57 & 7.00 & mass from mean of known estimates in genus \\
\hline Amebelodon sp. & 3810333 & 7.83 & 6.90 & mass from mean of estimates of $A$. floridanus in Christiansen (2004) \\
\hline Antecalomys valensis & 13 & 7.83 & 6.90 & \\
\hline Copemys esmeraldensis & 27 & 10.57 & 6.90 & \\
\hline Cupidinimus magnus & 23 & 8.30 & 6.90 & \\
\hline Dinohippus spectans & 536500 & 8.76 & 6.90 & \\
\hline Dipoides stirtoni & 2589 & 8.30 & 6.90 & \\
\hline Diprionomys parvus & 11 & 8.30 & 6.90 & \\
\hline Goniodontomys disjunctus & 58 & 7.83 & 6.90 & \\
\hline Hemiauchenia vera & 130000 & 7.50 & 6.90 & \\
\hline Hesperogaulus wilsoni & & 7.83 & 6.90 & \\
\hline Hippotherium sp. & 65100 & 10.57 & 6.90 & mass from mean of known estimates in genus \\
\hline Hypolagus vetus & 483 & 15.77 & 6.90 & \\
\hline Hystricops browni & 2500 & 7.83 & 6.90 & mass from $H$. venustus \\
\hline Indarctos oregonensis & 2097300 & 7.50 & 6.90 & \\
\hline Leptodontomys sp. & 6 & 10.57 & 6.90 & $\begin{array}{l}\text { some taxa in genus have mass below } 18 \mathrm{~g} \text {; however, there are real } \mathrm{m} 1 \\
\text { length and width measurements for "L. } s p . "\end{array}$ \\
\hline Liodontia furlongi & 198 & 8.76 & 6.90 & mass from L. alexandrae \\
\hline Lutravus halli & 5840 & 8.30 & 6.90 & \\
\hline Macrognathomys nanus & 5 & 10.57 & 6.90 & \\
\hline Martes sp. & 1767 & 10.57 & 6.90 & mass from mean of known estimates in genus \\
\hline Neohipparion leptode & 109200 & 8.30 & 6.90 & \\
\hline Peromyscus antiquus & 31 & 8.30 & 6.90 & \\
\hline
\end{tabular}


Table A. 3 continued.

\begin{tabular}{|c|c|c|c|c|}
\hline Peromyscus sp. & 18 & 7.50 & 6.90 & mass from mean of known estimates in genus \\
\hline Platygonus oregonensis & 98700 & 7.50 & 6.90 & \\
\hline Plionarctos sp. & 165500 & 7.50 & 6.90 & mass from $P$. harrolorum \\
\hline Scalopoides sp. & 30 & 10.57 & 6.90 & mass from mean of known estimates in genus \\
\hline Simocyon primigenius & 33900 & 7.50 & 6.90 & \\
\hline Spermophilus gidleyi & 700 & 7.50 & 6.90 & \\
\hline Tardontia sp. & 172 & 10.57 & 6.90 & mass from mean of known estimates in genus \\
\hline Castor sp. & 14087 & 7.10 & 5.90 & $\begin{array}{l}\text { mass from mean of known estimates in genus; check Silva and Downing } \\
\text { (2004) }\end{array}$ \\
\hline Dipoides sp. & 2669 & 7.50 & 5.90 & mass from mean of known estimates in genus \\
\hline Hypolagus oregonensis & 501 & 7.10 & 5.90 & \\
\hline Machairodus sp. & 72300 & 7.10 & 5.90 & \\
\hline Mammut sp. & 6310400 & 10.57 & 5.90 & mass from mean of estimates of $M$. americanum (Christiansen, 2004) \\
\hline Neotamias malloryi & 17 & 7.10 & 5.90 & \\
\hline Oregonomys pebblespringsensis & 27 & 7.10 & 5.90 & \\
\hline Perognathus stevei & 11 & 7.10 & 5.90 & \\
\hline Plesiogulo marshalli & 2820 & 7.10 & 5.90 & \\
\hline Pliotaxidea nevadensis & 2360 & 8.30 & 5.90 & \\
\hline Scapanus proceridens & 65 & 7.83 & 5.90 & \\
\hline Spermophilus shotwelli & 204 & 7.10 & 5.90 & mass from mean of known estimates in genus \\
\hline Spermophilus wilsoni & 248 & 7.83 & 5.90 & \\
\hline Sphenophalos sp. & & 7.83 & 5.90 & \\
\hline Teleoceras sp. & 883186 & 9.68 & 5.90 & mass from mean of known estimates in genus \\
\hline Epicyon saevus & 44300 & 8.30 & 5.10 & \\
\hline Ammospermophilus hanfordi & 58 & 4.48 & 4.38 & mass from mean of known estimates in genus \\
\hline Bretzia pseudalces & & 4.48 & 4.38 & \\
\hline Dipoides rexroadensis & 7095 & 4.48 & 4.38 & \\
\hline Eucyon davisi & 9000 & 8.30 & 4.38 & \\
\hline Megalonyx rohrmanni & 3050996 & 4.48 & 4.38 & mass from mean of known estimates in genus \\
\hline Megatylopus cochrani & 1383500 & 4.48 & 4.38 & \\
\hline
\end{tabular}


Table A. 3 continued.

\begin{tabular}{|c|c|c|c|c|}
\hline Nekrolagus progressus & & 4.48 & 4.38 & \\
\hline Ophiomys mcknighti & 111 & 4.48 & 4.38 & \\
\hline Paenemarmota sawrockensis & 5926 & 4.48 & 4.38 & \\
\hline Paracryptotis rex & 42 & 4.48 & 4.38 & \\
\hline Peromyscus nosher & 16 & 4.48 & 4.38 & \\
\hline Scapanus sp. & 97 & 8.30 & 4.38 & mass from mean of known estimates in genus \\
\hline Baiomys aquilonius & & 3.60 & 3.19 & mass from mean of known estimates in genus, but below $18 \mathrm{~g}$ \\
\hline Baiomys sp. & 8 & 3.60 & 3.19 & $\begin{array}{l}\text { genus mass below } 18 \mathrm{~g} \text {; however, there are real } \mathrm{m} 1 \text { length and width } \\
\text { measurements for "B. } s p . "\end{array}$ \\
\hline Borophagus hilli & 52700 & 4.48 & 3.19 & \\
\hline Cosomys primus & 164 & 3.60 & 3.19 & \\
\hline Megalonyx sp. & 3050996 & 7.50 & 3.19 & mass from mean of known estimates in genus \\
\hline Megantereon hesperus & 56900 & 3.60 & 3.19 & \\
\hline Mimomys sp. & 126 & 3.60 & 3.19 & mass from mean of known estimates in genus \\
\hline Neotoma quadriplicata & 381 & 4.48 & 3.19 & \\
\hline Oregonomys magnus & 21 & 3.60 & 3.19 & \\
\hline Paenemarmota barbouri & 10255 & 3.60 & 3.19 & \\
\hline Perognathus maldei & 11 & 3.60 & 3.19 & \\
\hline Peromyscus hagermanensis & 20 & 3.60 & 3.19 & \\
\hline Pliogeomys parvus & 10 & 3.60 & 3.19 & \\
\hline Procastoroides intermedius & 12955 & 3.60 & 3.19 & \\
\hline Prodipodomys idahoensis & 22 & 3.60 & 3.19 & \\
\hline Scapanus hagermanensis & 97 & 3.60 & 3.19 & mass from mean of known estimates in genus \\
\hline Sorex hagermanensis & 7 & 3.60 & 3.19 & \\
\hline Sorex powersi & 8 & 4.48 & 3.19 & \\
\hline Sorex rexroadensis & 8 & 3.60 & 3.19 & mass from mean of known estimates in genus \\
\hline Ursus abstrusus & 145500 & 3.60 & 3.19 & \\
\hline Alilepus vagus & 259 & 3.60 & 2.98 & \\
\hline Alilepus wilsoni & 146 & 3.08 & 2.98 & \\
\hline
\end{tabular}


Table A.3 continued.

\begin{tabular}{|c|c|c|c|c|}
\hline Bassariscus casei & 832 & 3.08 & 2.98 & \\
\hline Borophagus diversidens & 75400 & 3.08 & 2.98 & \\
\hline Buisnictis breviramus & 255 & 3.60 & 2.98 & \\
\hline Capromeryx tauntonensis & 21600 & 3.08 & 2.98 & \\
\hline Dinofelis palaeoonca & 87800 & 3.08 & 2.98 & \\
\hline Equus simplicidens & 204300 & 4.48 & 2.98 & \\
\hline Hemiauchenia macrocephala & 342900 & 3.08 & 2.98 & \\
\hline Hypolagus ringoldensis & 319 & 4.48 & 2.98 & mass from mean of known estimates in genus \\
\hline Megalonyx leptostomus & 2934720 & 3.08 & 2.98 & \\
\hline Nekrolagus sp.? & & 3.08 & 2.98 & \\
\hline Neotoma fossilis & 150 & 3.08 & 2.98 & \\
\hline Odocoileus sp.? & 101933 & 3.08 & 2.98 & mass from mean of known estimates in genus \\
\hline Ophiomys taylori & 81 & 3.60 & 2.98 & \\
\hline Parailurus sp. & & 3.08 & 2.98 & \\
\hline Platygonus sp. & 149940 & 3.08 & 2.98 & mass from mean of known estimates in genus \\
\hline Plionarctos harroldorum & 165500 & 4.48 & 2.98 & \\
\hline Procastoroides idahoensis & 66745 & 3.08 & 2.98 & \\
\hline Procyon sp.? & 5353 & 3.08 & 2.98 & mass from mean of known estimates in genus \\
\hline Prodipodomys sp. & 19 & 3.08 & 2.98 & mass from mean of known estimates in genus \\
\hline Puma lacustris & 27900 & 3.08 & 2.98 & \\
\hline Rangifer sp.? & 16900 & 3.08 & 2.98 & \\
\hline Sorex meltoni & 4 & 3.60 & 2.98 & \\
\hline Sorex sp. & 8 & 3.08 & 2.98 & mass from mean of known estimates in genus \\
\hline Spermophilus howelli & 140 & 3.08 & 2.98 & \\
\hline Spermophilus russelli? & 166 & 4.48 & 2.98 & \\
\hline Spilogale sp. & 586 & 3.08 & 2.98 & mass from mean of known estimates in genus \\
\hline Taxidea sp. & 5290 & 3.60 & 2.98 & mass from $T$. taxus \\
\hline Thomomys gidleyi & 37 & 4.48 & 2.98 & \\
\hline Borophagus sp. & 50725 & 3.60 & 1.68 & mass from mean of known estimates in genus \\
\hline
\end{tabular}


Table A. 3 continued.

\begin{tabular}{|c|c|c|c|c|}
\hline Canis lepophagus & 17000 & 3.60 & 1.68 & \\
\hline Castor californicus & 12965 & 4.48 & 1.68 & \\
\hline Ceratomeryx prenticei & & 3.60 & 1.68 & \\
\hline Cervus sp.? & 112483 & 3.60 & 1.68 & mass from mean of known estimates in genus (Silva and Downing, 2004) \\
\hline Equus fromanius & 172311 & 1.85 & 1.68 & mass from mean of known estimates in genus \\
\hline Equus idahoensis & 205200 & 1.85 & 1.68 & \\
\hline Felis rexroadensis & 24500 & 3.60 & 1.68 & \\
\hline Ferinestrix vorax & & 3.60 & 1.68 & \\
\hline Gigantocamelus spatulus & 1669500 & 1.85 & 1.68 & \\
\hline Homotherium idahoensis & 257900 & 1.85 & 1.68 & \\
\hline Homotherium sp. & 196425 & 3.60 & 1.68 & mass from mean of known estimates in genus \\
\hline Hypolagus edensis & 120 & 3.60 & 1.68 & \\
\hline Hypolagus furlongi & 191 & 3.60 & 1.68 & \\
\hline Hypolagus gidleyi & 400 & 3.60 & 1.68 & \\
\hline Hypolagus voorhiesi & 319 & 3.60 & 1.68 & mass from mean of known estimates in genus \\
\hline Mictomys vetus & 181 & 3.60 & 1.68 & \\
\hline Mustela rexroadensis & 132 & 3.60 & 1.68 & \\
\hline Ondatra idahoensis & 698 & 3.60 & 1.68 & \\
\hline Ondatra minor & 461 & 3.60 & 1.68 & \\
\hline Ophiomys meadensis & 86 & 3.60 & 1.68 & \\
\hline Ophiomys parvus & 99 & 3.60 & 1.68 & \\
\hline Phenacomys gryci & 228 & 1.85 & 1.68 & mass from mean of known estimates in genus \\
\hline Platygonus pearcei & 149940 & 4.48 & 1.68 & mass from mean of known estimates in genus \\
\hline Pliophenacomys osborni & 86 & 3.60 & 1.68 & \\
\hline Procastoroides sp. & 38180 & 3.60 & 1.68 & mass from mean of known estimates in genus \\
\hline Satherium piscinarium & 18100 & 3.60 & 1.68 & \\
\hline Sminthosinis bowleri & 1480 & 3.60 & 1.68 & \\
\hline Sminthosinis sp. & 1480 & 3.60 & 1.68 & mass from S. bowleri \\
\hline Sorex palustris & 13 & 1.85 & 1.68 & \\
\hline
\end{tabular}


Table A.3 continued.

\begin{tabular}{|c|c|c|c|c|}
\hline Stegomastodon mirificus & 5491333 & 1.85 & 1.68 & mass from mean of estimates of S. platensis (Christiansen, 2004) \\
\hline Thomomys sp. & 73 & 3.60 & 1.68 & mass from mean of known estimates in genus \\
\hline Trigonictis cookii & 3130 & 3.60 & 1.68 & \\
\hline Trigonictis macrodon & 5680 & 4.48 & 1.68 & \\
\hline Trigonictis sp. & 4587 & 3.60 & 1.68 & mass from mean of known estimates in genus \\
\hline Canis edwardii & 31100 & 0.90 & 0.30 & \\
\hline Hemiauchenia sp. & 212040 & 4.48 & 0.20 & mass from mean of known estimates in genus \\
\hline Camelops sp. & 1409200 & 3.08 & 0.10 & mass from mean of known estimates in genus \\
\hline Cervus brevitrabalis? & 112483 & 0.20 & 0.10 & mass from mean of known estimates in genus (Silva and Downing, 2004) \\
\hline Equus sp. & 172311 & 3.60 & 0.10 & mass from mean of known estimates in genus \\
\hline Mammut americanum & 6310400 & 4.48 & 0.10 & mass from mean of estimates of M. americanum (Christiansen, 2004) \\
\hline Panthera onca & 97500 & 0.90 & 0.10 & \\
\hline Paramylodon harlani & & 3.60 & 0.10 & \\
\hline Puma concolor & 56700 & 1.85 & 0.10 & \\
\hline Taxidea taxus & 5290 & 0.20 & 0.10 & \\
\hline Lynx canadensis & 10900 & 0.20 & 0.00 & \\
\hline Lynx rufus & 8560 & 3.08 & 0.00 & \\
\hline Odocoileus hemionus & 96500 & 0.20 & 0.00 & \\
\hline
\end{tabular}


Appendix B. Multimodality testing

Testing for multimodality

Histograms are a frequently used method for demonstrating frequency

distributions in data. Textbook distributions are typically bell-shaped (symmetric with mean, median, and mode the same) or skewed with one mode (unimodal; Bluman, 2004).

However, distributions of data can have more than one mode (U-shaped, bimodal, trimodal, etc.) or no modes at all (uniform; Bluman, 2004). For a more detailed analysis of the modes, a density distribution can be calculated using a kernel density estimate $f$ with a bandwidth $h$ and kernel function $K$ over which the data are analyzed (Silverman, 1981, 1986). I ran this test on log-transformed data using natural logs and bins of size 0 to 1,1 to 2 , etc.

\section{Kernel density estimation}

To calculate a kernel density estimate the following equation is used:

$$
f(x ; h)=\frac{1}{n h} \sum_{i=1}^{n} K\left(\left(x-X_{i}\right) / h\right) .
$$

Here, $x$ is the bin size (as equal increments starting at zero to $x_{i}, x_{i}$ to $x_{i+1}$, etc.) and $n$ is the number of samples that fall in each bin; there is no set number of $n$ per bin. $X_{i}$ is one observation out of $n$ observations to fall in bin $x$. $h$ is the window width (aka the bandwidth or smoothing parameter) which may overlap bin $x$ and a fraction of the next or $h$ may be just a fraction of bin size $x_{i}$ to $x_{i+1} . h$ may also overlap multiple bins. The kernel function $K$ may be Gaussian, Epanechnikov, Biweight, Triangular, or Rectangular to 
name a few (see illustration of these in Table 3.1 on page 43 in Silverman, 1986). The type of kernel function did not affect the outcome of the test.

\section{Critical window width}

As the window width, $h$, increases it smoothes out the density function by estimating across multiple bins and thus decreasing the resolution of the bin-sampled data. The result of this process is that if a distribution has multiple modes, a larger and larger $h$ will eventually generate unimodal density estimation (Silverman, 1981; 1986). Finding the $h$ that is the transition point at which a density estimation changes from a higher modality to a lower modality (e.g. trimodal to bimodal and bimodal to unimodal) is the critical window width $h_{\text {crit. }}$ The method applied in this report is a binary search procedure that calculates the midpoint of a chosen window interval $\left(h_{\mathrm{lo}}, h_{\mathrm{hi}}\right)$ and every subsequent midpoint in the direction of $h_{\text {crit }}$ (Silverman, 1981, 1986). I found for the kernel density estimation of the PNW mammalian mass data $h_{\text {crit }}$ is approximately 2.3.

Jones' test of $h_{\text {crit }}$

A simulation study in a dissertation by Jones (1983) reveals that $5 \%$ of samples drawn from normal distributions with a standard deviation of $\sigma$ have $h_{\text {crit }}$ greater than $h=$ $1.25 \sigma m^{-0.2}$, where $m$ is the total sample size ranging as $40 \leq{ }^{\leq} \leq 5000$. In this case, with a $\sigma=3.641$ and $m=378, h=0.2946$ which is certainly smaller than 2.3 indicating a 95\% probability that the Cenozoic PNW mammalian mass data are highly bimodal. 
Appendix C: Potential barriers and corridors to migration and gene flow in the late Miocene Pacific Northwest

Isolation for peripatric speciation in the late Miocene Pacific Northwest (LMPN) perhaps required relatively large pre-existing barriers (i.e. topographic highs, large water bodies) positioned jointly with the sudden and massive ash-flow eruptions. However, it cannot be dismissed that some populations perhaps migrated over or through barriers by which they are usually bounded. Below is a description of potential physiographic barriers and corridors to population migrations in the LMPN that surround the source region (Harney Basin) for the widespread eruptions such as the DvCT, PCT, and RST. The information available is made possible by a diverse array of data and analytical techniques from fossil leaf physiognomy to isotopes in fossil tooth enamel to regional syntheses of local structural relationships.

The mountains

In the LMPN, the geographic positions of a number of potential barriers and corridors are similar to ones that exist today. The Western Cascades in Oregon are estimated to be approximately at heights of $800 \mathrm{~m}$ based on $\delta^{18} \mathrm{O}$ isotopes in fossil tooth enamel of perissodactyls (i.e. equids and rhinocerotids; Kohn et al., 2002; Kohn and Dettman, 2007; Kohn and Fremd, 2007). Evidence in the rock record providing estimates of total thicknesses of deposits in this range is difficult to evaluate since today vegetation covers much of what would be exposed (du Bray et al., 2006). The bulk of the deposits are seen in the Sardine (Thayer, 1937) and Troutdale (Beeson and Tolan, 1987) 
Formations with the majority of the Sardine eruptions and Troutdale fluvial deposits occurring between 13 and 9 Ma (Orr et al., 1999) and 12 and $6 \mathrm{Ma}$ (Beeson and Tolan, 1987), respectively. Though perhaps not as high as the present-day High Cascades, the Western Cascades would have covered a wider area with the earliest eruptions to the west (42 Ma) and youngest to the east (10 Ma). This eastward trend of eruptions is attributed to clockwise rotation and the then shallowing of the subducting Farallon Plate (Orr et al., 1999). The volcanic activity only temporally overlaps with the eruption of the DvCT, while the Troutdale fluvial deposits are contemporaneous with all three ash-flows (DvCT, PCT, and RST). Additionally, Reiners et al. (2002) indicate the Washington Cascades were being uplifted at a rate of $0.5-1 \mathrm{~km} / \mathrm{m}$.y. from 12 to $8 \mathrm{Ma}$. The LMPN Western Cascades extended from approximately $48^{\circ} \mathrm{N}$ latitude in northwestern Washington (duBray et al., 2006) to perhaps as far south as the Tahoe-Reno area in California (Cousens et al., 2008).

The Klamath Mountains were much higher in the LMPN than they are today. Based on estimates of Mortimer and Coleman (1985), an approximately 70,000 $\mathrm{km}^{2}$ dome centered on Condrey Mountain just south of the California-Oregon border may have raised this area of the Klamath Mountains up to a maximum of $7000 \mathrm{~m}$ from 14 to 5 Ma. Today, the elevation of Condrey Mountain is $2168 \mathrm{~m}$. Causes for the doming are unclear at present, but may be due to eastward compression (Mortimer and Coleman, 1985).

In the Basin and Range, Wolfe et al. (1997) indicate that range heights were similar to today. These estimates are based on approximations of enthalpy related to 
measurements of fossil leaf characteristics (e.g. leaf margin, size, apical and basal configurations, length to width ratios, and general foliar shape as just six parameters of the 29 evaluated by this method). The Basin and Range today extends into Oregon south of Harney Basin as expressed in Steens Mountain and Hart Mountain. Steens Mountain was perhaps uplifted in the late Miocene. Evidence for this lies in two parts: 1) the DvCT (9.7 Ma) is observed on the eastside of Steens Mountain while the PCT and RST are only observed to the west of the uplifted block (Streck and Ferns, 2004). Despite this, Singleton and Oldow (2004) indicate deformation of the Alvord-Steens fault system initiated after $7 \mathrm{Ma}$ based on volcaniclastic sediments being cross-cut by the fault system. 2) At approximately $10 \mathrm{Ma}$ is when the first eruptions at the north end of Steens Mountain begin in the Brothers Fault Zone and continue to erupt further away to the northwest as time passes (Camp and Ross, 2004). This potentially indicates structural stress related to clockwise rotation (Orr et al., 1999) or an expanding plume head (Camp and Ross, 2004). Perhaps in this time (10-7 Ma) Steens Mountain attained comparable elevations as today or already was an area of considerable topographic relief after the DvCT erupted. It is unclear if the Brothers Fault Zone and the Alvord-Steens fault system are related (Pezzopane and Weldon, 1993).

Southeast of Steens Mountain the track of the Yellowstone Hotspot had developed the McDermitt (16.5-15 Ma), Owyhee-Humbolt (14-12 Ma), and BruneauJarbridge (12.5-11 Ma) volcanic fields and was in the process of developing the Twin Falls (12-6.5 Ma) and Picabo (10.5-6.5 Ma) volcanic fields (Beranek et al., 2006). These volcanic fields may have attained elevations of $1000 \mathrm{~m}$ and stood as a continental divide 
(Pierce and Morgan, 1992; Beranek et al., 2006) much like at Yellowstone National Park today. Moreover, Beranek et al. (2006) found isotopic evidence from detrital zircons in regional sediments suggesting that the McDermitt, Owyhee-Humbolt, and BruneauJarbridge volcanic fields acted together as a northeast trending drainage divide. In addition to the elevated volcanic fields, the Atlanta lobe of the Idaho Batholith was uplifted and contemporary with the hotspot bulge of the Twin Falls and Picabo volcanic fields (Beranek et al., 2006). Together these features were likely a topographic high from northern Idaho and western Montana down to northeastern Nevada by 9 Ma.

West of the Atlanta lobe the elevation of the Wallowa Mountains was $2000 \mathrm{~m}$ by $10 \mathrm{Ma}$ according to Hales et al. (2005). This uplift followed a potential brief subsidence and was simultaneous with initial eruptions of Columbia River basalt. Uplift is suggested by Hales et al. (2005) to be produced by convective upwelling and detachment of a plutonic root which arrived at isostatic equilibrium by $12 \mathrm{Ma}$.

Blue Mountain uplift is considered to have begun in the early Oligocene $(\sim 30$ Ma). Robinson et al. (1990) observe that the eastern sub-region (cf Robinson et al.'s [1990] "facies") of the John Day Formation pinches out northeast of the town of Kinzua where middle Miocene Picture Gorge Basalt overlies the Eocene-Oligocene Clarno Formation. The Picture Gorge ash-flow tuff of the John Day Formation (28.7 Ma; aka Picture Gorge ignimbrite [PGI] of Fisher and Rensberger, 1972) is not found in the western sub-region of the John Day Formation. The phenomenon is the same for ash-flow tuffs in the western subregion where sediments also pinch out against a "Clarno high" (Robinson et al., 1990). Only ash fall tuffs (e.g. Deep Creek tuff) can be found in both 
western and eastern subregions of the John Day Formation (Robinson et al., 1990). Interestingly, in the Paulina Basin (southern sub-region), the PGI is apparently very distal (T. Fremd, pers. comm., 2007). This might indicate that the Ochoco Mountains were uplifted subsequently to $28.7 \mathrm{Ma}$. It may be that later structural deformation of the area continued into the earliest Miocene. The Kimberly Member in the eastern sub-region of the John Day Formation is capped in some localities by erosional unconformity followed by Picture Gorge Basalt representing a hiatus of eight million years (Hunt and Stepleton, 2004). However, by the time of the eruption of the Harney Basin tuffs the region may have produced the bulk of its deformation as indicated by 1) few faults cross-cutting the overlying Deschutes Formation (10-8 Ma; this is confusing however, because Smith (1985) has constrained the age of the Deschutes Formation as $~ 7.6-4$ Ma from the dated Pelton Basalt and Round Butte Basalt, respectively) west of the Blue Mountains (Farooqui et al., 1981; Robinson et al., 1990) and 2) Streck and Grunder (1995) observing Aldrich Mountain as a potential "hurdle" for the RST to pass over. However, uplift may not be uniform throughout the region as indicated by fanglomerates in the Rattlesnake Formation ( 7.5-7.05 Ma; Retallack et al., 2002) in western John Day Valley.

The Strawberry Mountains were present in the LMPN. However, their activity had largely ceased by $10 \mathrm{Ma}$ (Walker, 1990). By this time of eruptive cessation, the Strawberry Mountains had built up 2000 m of a diverse array of volcanic deposits over $3400 \mathrm{~km}^{2}$ near the eastern end of the John Day Valley (Walker, 1990).

The rivers 
Prior to the Pliocene the ancestral Columbia River flowed north of its present border position at north-central Oregon and south-central Washington (Fecht et al., 1987). Following the emplacement of the Priest Rapids Member (14.5 Ma) of the Wanapum Basalt Formation (Columbia River Basalt Group [CRBG]), the ancestral Columbia River established the Bridal Veil channel that traversed from approximately 20 to $30 \mathrm{~km}$ north of its position at The Dalles, Oregon to approximately line up with the modern channel's course at Hood River, Oregon. The Bridal Veil channel lasted through the late Miocene into the early Pliocene (Beeson and Tolan, 1987). Compressional folding and rapid uplift of the High Cascades region has since made the river antecedent in its present location through the Columbia River Gorge (perhaps since $\sim 2 \mathrm{Ma}$; Beeson and Tolan, 1987). Further east, Fecht et al. (1987) indicate in the late Miocene to middle Pliocene the ancestral Clearwater-Salmon River captured the ancestral Yakima-Columbia River channel in the subsiding Pasco Basin of the central Columbia Plateau following the deposition of the Ice Harbor Member (8.5 Ma) of the Saddle Mountains Basalt. The Ice Harbor Member underlies the Ringold Formation (8.5 - 3.4 Ma; Fecht et al., 1987) in Pasco Basin. However, it appears in Figures 11 and 12 of Fecht et al.'s (1987) report that the Lower Monumental Member (6 Ma) of the Saddle Mountains Basalt is deposited prior to this river capture event. No middle to late Miocene confluence further west between these two ancestral streams has been proposed by either report. It appears there is some likelihood the ancestral Clearwater-Salmon River flowed west south of the ancestral Yakima-Columbia River in the late Miocene. Perhaps this confluence took place north of present-day Mt. Hood. 
The ancestral John Day River was sourced by continued uplift of the Blue Mountains and surrounding region in the late Miocene. Retallack et al. (2002) indicate Picture Gorge Basalt, Mascal and John Day Formation sediments, and ash falls from the east and south of the region were the materials that were deposited to form Rattlesnake Formation paleosols in the western John Day Valley. Moreover, clast imbrication measurements indicate the paleodrainage flowed southeast down the axis of the valley (as illustrated by isopachs of the RST (Streck and Grunder, 1995)) prior to being choked with thicker and coarser alluvial fan material with channels flowing south (Retallack et al., 2002). Perhaps this indicates that the John Day River flowed southeast to Lake Idaho ( 9.5-2.5 Ma; Beranek et al., 2006) in the western Snake River Plain or somehow was associated with some ancestral river coarse to the north (ancestral Clearwater-Salmon River?). Today the John Day River flows northeast in the John Day Valley before its incision through Picture Gorge Basalt and the John Day Formation finally joins with the Columbia River.

The ancestral Deschutes River as indicated from paleocurrent measurements in sediments below "valley" filling basalt flows of the Pelton Basalt ( 7.6 Ma; Smith and Snee, 1984) indicate a northward flow (Smith, 1985). Smith (1985) further describes evidence for only a single main stream in the southern Deschutes River Valley as opposed to two (Deschutes and Crooked Rivers) today.

The ancestral Snake River is more of a mystery than other major rivers in the Pacific Northwest. Wheeler and Cook (1954) indicate that the direction of the Snake River today would not have been established until approximately $2.5 \mathrm{Ma}$ by forging an 
outlet for Lake Idaho through the uplifted Wallowa Mountains. The ancestral Snake River is suggested to have flowed either through southeastern Oregon (Wheeler and Cook, 1954; Minckley et al., 1986) or through northern Utah and Nevada (Minckley et al., 1986; Repenning et al., 1995; Link et al., 2002; Hershler and Liu, 2004). To date, no clear geological evidence supports these proposals while it is known that multiple rivers such as the ancestral Owyhee River flowing north through the Oregon Idaho graben (Cummings et al., 2000) and streams of the eastern Snake River Plain (Beranek et al., 2006) flowed into the internal drainage system of Lake Idaho. However, in a summary by Carney and Page (1990), it appears there are potential linkages of the Klamath Basin (Oregon) and Mohave Basin (southern Great Basin) to the ancestral Snake River established on the basis of paleoichtheological relationships between the fossil Teleost fish Ptychocheilus arciferus of the Glens Ferry Formation (5 - $3 \mathrm{Ma})$ in Idaho and its descendent relatives, $P$. oregonensis — of present-day Oregon, Washington, and Idahoand $P$. grandis in the Sacramento Basin in California.

The basins

Multiple basins, such as the Deschutes, Tygh Valley, Dalles, Arlington, Agency, Walla Walla, John Day, Paulina, Harney, Juntura, Harper, and Boise basins were present 10 to seven Ma (Walker, 1990). Most of these basins are constrained by age-dated basalt flows and tuffs and/or with paleontological evidence. Harney Basin itself is considered to have been subsiding gradually with the release of the three major ash-flow tuffs, DvCT, PCT, and RST (Walker, 1979). Northeast of present-day Steens Mountain subsidence of 
the Oregon-Idaho graben was complete (15.5-10.5 Ma; Cummings et al., 2000), while subsidence of the western Snake River Plain had begun thereafter $(\sim 11 \mathrm{Ma}$; Beranek et al., 2006).

Regarding the central region of Oregon, measured thicknesses of the DvCT $(<35$ m; Greene, 1973) and RST (<70 m; Streck and Grunder, 1995) indicate low relief topography throughout most areas as indicated by uniform thicknesses. Where the RST is at its thickest, it is thicker than where the DvCT is at its thickest. Some regions with RST, such as the John Day Valley and south of Harney Basin, might have been areas of much lower elevation as the thicknesses are greater there than in their respective surrounding landscapes (Streck and Grunder, 1995). 


\section{Appendix D. FVC-Albedo data table}

Table D. 14 observations of $F V C$ (\%) and Albedo (\%) for different biomes throughout the world.

\begin{tabular}{llll}
\hline Biome & FVC (\%) & Albedo (\%) & Albedo Source \\
\hline \hline forest/woodland & $0.924^{*}$ & 0.24 & Fuller and Ottke, 2002 \\
forest/woodland & $0.924^{*}$ & $0.125^{*}$ & Barry and Chorely, 1992 \\
forest/woodland & $0.924^{*}$ & $0.1065^{*}$ & Betts and Ball, 1997 \\
grass/sav & $0.755^{*}$ & 0.31 & Fuller and Ottke, 2002 \\
grass/sav & $0.755^{*}$ & $0.476^{*}$ & Betts and Ball, 1997 \\
woody grass/sav & 0.88 & 0.25 & Fuller and Ottke, 2002 \\
woody grass/sav & 0.88 & $0.215^{*}$ & Barry and Chorely, 1992 \\
woody grass/sav & 0.88 & $0.180^{*}$ & Betts and Ball, 1997 \\
crop & 0.87 & 0.23 & Fuller and Ottke, 2002 \\
crop & 0.87 & $0.215^{*}$ & Barry and Chorely, 1992 \\
urban & 0.79 & 0.24 & Fuller and Ottke, 2002 \\
closed shrub & 0.76 & 0.33 & Fuller and Ottke, 2002 \\
open shrub & 0.42 & 0.45 & Fuller and Ottke, 2002 \\
barren & 0.14 & 0.53 & Fuller and Ottke, 2002 \\
\hline
\end{tabular}

FVC data from Zeng et al., 2003.

* Averaged from given range 


\section{Appendix E. AE-MAP regression data table}

Table E. 15 observations of $A E, M A P_{\min }, M A P_{\max }$, and $M A P_{\text {mean }}$ for different locations throughout the world. $A E$ data from Rosenzweig (1968). $A E$ and $M A P_{\text {mean }}$ were regressed with a zero intercept as $A E=$ $0.6719 M A P_{\text {mean }}$

\begin{tabular}{|c|c|c|c|c|c|}
\hline$A E$ & $M A P_{\min }$ & $M A P_{\max }$ & $M A P_{\text {mean }}$ & Location & MAP reference \\
\hline 126 & 127 & 254 & 191 & Nye Co. NV & nationalatlas.gov \\
\hline 200 & 200 & 410 & 305 & Cape Thompson, AK & Worldbook.com \\
\hline 617 & 762 & 889 & 826 & Norman, OK & nationalatlas.gov \\
\hline 562 & 750 & 1000 & 875 & Toronto, ON & statcan.gc.ca \\
\hline 1230 & 1250 & 2500 & 1875 & Kade, Ghana & bestcontryreports.com \\
\hline 1318 & 1241 & 2432 & 1709 & Yangambi, D.R. Congo & Wilkie et al., 1999 \\
\hline 219 & 254 & 381 & 318 & Rexburg, ID & nationalatlas.gov \\
\hline 832 & 1270 & 1524 & 1397 & Oak Ridge, TN & nationalatlas.gov \\
\hline 178 & 127 & 254 & 191 & Hanford Res., WA & nationalatlas.gov \\
\hline 1000 & - & - & 1500 & Darwin, AUS & $\begin{array}{l}\text { bom.gov.au; } \\
\text { yprl.vic.gov.au }\end{array}$ \\
\hline 650 & 900 & 1200 & 1050 & Sydney, AUS & $\begin{array}{l}\text { bom.gov.au; } \\
\text { yprl.vic.gov.au }\end{array}$ \\
\hline 350 & 300 & 600 & 450 & Port Headland, AUS & $\begin{array}{l}\text { bom.gov.au; } \\
\text { yprl.vic.gov.au }\end{array}$ \\
\hline 528 & - & - & 745 & $\begin{array}{l}\text { El Destierro I }(550 \mathrm{~m}) \text {, } \\
\text { Argentina }\end{array}$ & Perez and Frangi, 2000 \\
\hline 503 & - & - & 786 & $\begin{array}{l}\text { El Destierro I }(850 \mathrm{~m}) \text {, } \\
\text { Argentina }\end{array}$ & Perez and Frangi, 2000 \\
\hline 465 & - & - & 828 & $\begin{array}{l}\text { El Destierro I (1025 m), } \\
\text { Argentina }\end{array}$ & Perez and Frangi, 2000 \\
\hline
\end{tabular}

